CAROLINA PICCOLOTTO GALIB GIOVANNA BALDAN

PEDRO AUGUSTO DE CASTRO SIMBERA (ORGANIZADORES)

\title{
PRÁTICA JURÍDICA
}

EM DIREITOS HUMANOS:

\section{ESTUDOS DE CASOS}


CAROLINA PICCOLOTTO GALIB GIOVANNA BALDAN

PEDRO AUGUSTO DE CASTRO SIMBERA (ORGANIZADORES)

\section{PRÁTICA JURÍDICA \\ EM DIREITOS HUMANOS:}

\section{ESTUDOS DE CASOS}


2020 by Editora e-Publicar

Copyright $(C)$ Editora e-Publicar

Copyright do Texto $(C) 2020$ Os autores

Copyright da Edição (C) 2020 Editora e-Publicar

Direitos para esta edição cedidos à Editora e-Publicar pelos autores.

\author{
Editora Chefe \\ Patrícia Gonçalves de Freitas \\ Editor \\ Roger Goulart Mello \\ Diagramação \\ Roger Goulart Mello \\ Projeto gráfico e Edição de Arte \\ Patrícia Gonçalves de Freitas \\ Revisão \\ Os Autores
}

Todo o conteúdo dos artigos, dados, informações e correções são de responsabilidade exclusiva dos autores. O download e compartilhamento da obra são permitidos desde que os créditos sejam devidamente atribuídos aos autores. É vedada a realização de alterações na obra, assim como sua utilização para fins comerciais.

A Editora e-Publicar não se responsabiliza por eventuais mudanças ocorridas nos endereços convencionais ou eletrônicos citados nesta obra.

\title{
Conselho Editorial
}

Dr ${ }^{\mathrm{a}}$ Cristiana Barcelos da Silva - Universidade Estadual do Norte Fluminense Darcy Ribeiro

Dr $^{\mathrm{a}}$ Elis Regina Barbosa Angelo - Pontifícia Universidade Católica de São Paulo

Dr. Rafael Leal da Silva - Universidade Federal do Rio Grande do Norte

Dr. Fábio Pereira Cerdera - Universidade Federal Rural do Rio de Janeiro

$\mathrm{Dr}^{\mathrm{a}}$ Danyelle Andrade Mota - Universidade Tiradentes

Me. Doutorando Mateus Dias Antunes - Universidade de São Paulo

Me. Doutorando Diogo Luiz Lima Augusto - Pontifícia Universidade Católica do Rio de Janeiro

Me. Doutorando Francisco Oricelio da Silva Brindeiro - Universidade Estadual do Ceará

$\mathrm{M}^{\mathrm{a}}$ Doutoranda Bianca Gabriely Ferreira Silva - Universidade Federal de Pernambuco

$\mathrm{M}^{\mathrm{a}}$ Doutoranda Andréa Cristina Marques de Araújo - Universidade Fernando Pessoa

Me. Doutorando Milson dos Santos Barbosa - Universidade Tiradentes

$\mathrm{M}^{\mathrm{a}}$ Doutoranda Jucilene Oliveira de Sousa - Universidade Estadual de Campinas

$\mathrm{M}^{\mathrm{a}}$ Doutoranda Luana Lima Guimarães - Universidade Federal do Ceará

$\mathrm{M}^{\mathrm{a}}$ Cristiane Elisa Ribas Batista - Universidade Federal de Santa Catarina 
$\mathrm{M}^{\mathrm{a}}$ Andrelize Schabo Ferreira de Assis - Universidade Federal de Rondônia

Me.Daniel Ordane da Costa Vale - Pontifícia Universidade Católica de Minas Gerais

Me.Glaucio Martins da Silva Bandeira - Universidade Federal Fluminense

Me. Jose Henrique de Lacerda Furtado - Instituto Federal do Rio de Janeiro

$\mathrm{M}^{\mathrm{a}}$ Luma Mirely de Souza Brandão - Universidade Tiradentes

Dra $^{\mathrm{a}}$. Rita Rodrigues de Souza - Universidade Estadual Paulista

Dr. Helio Fernando Lobo Nogueira da Gama - Universidade Estadual De Santa Cruz

Dr. Willian Douglas Guilherme - Universidade Federal do Tocantins

Dr ${ }^{\mathrm{a}}$. Naiola Paiva de Miranda - Universidade Federal do Ceará

Dra . Dayanne Tomaz Casimiro da Silva - UFPE - Universidade Federal de Pernambuco

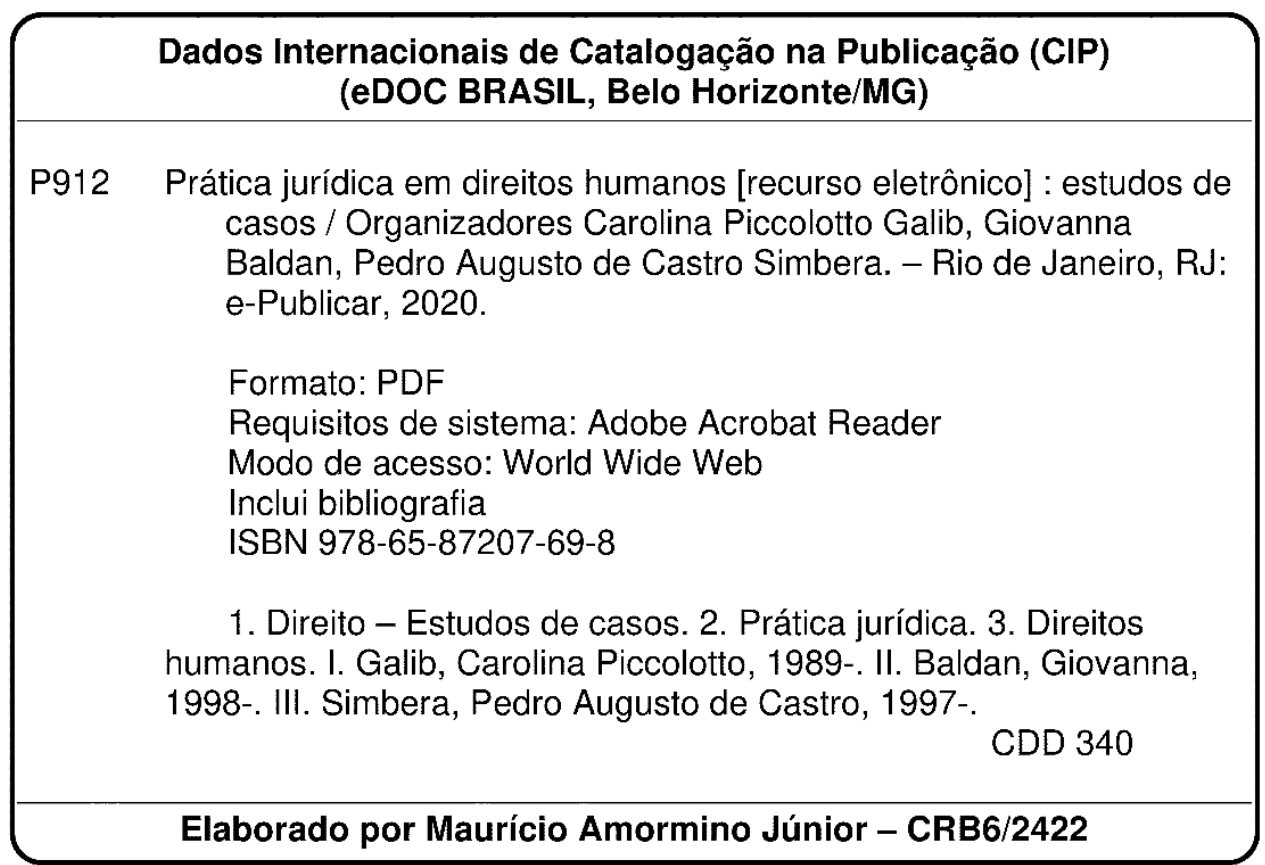

\section{Editora e-Publicar}

Rio de Janeiro - RJ - Brasil

contato@editorapublicar.com.br

www.editorapublicar.com.br 


\section{SOBRE A IMPORTÂNCIA DO ENSINO DE PRÁTICA DE DIREITOS HUMANOS}

A partir da Constituição de 1988 e do processo de redemocratização brasileira houve uma clara opção pelo Constituinte Originário em realizar um diálogo com o Sistema Internacional de Direitos Humanos. Nota-se que ao longo do texto constitucional de 1988 há diversos dispositivos que explicitam a abertura da ordem interna à ordem internacional, como por exemplo, o artigo $4^{\circ}$ e incisos, com destaque o inciso II que evoca a prevalência dos direitos humanos. Ademais, o artigo $5^{\circ}, \S 2^{\circ}$, do referido diploma constitucional, evoca a constante evolução dos direitos humanos, pois reconhece a existência de outros direitos previstos em tratados internacionais, bem como, o $\S 3^{\circ}$ do mesmo dispositivo, este pós reforma constitucional de 2004, e indica que tratados e convenções de direitos humanos aprovados pelo rito de emenda constitucional, terão hierarquia desta modalidade legislativa.

É importante rememorar também que o processo de criação de um sistema de direitos humanos pautado na positivação jurídica das normas se inicia no pós segunda guerra mundial, o que faz prevalecer na ordem internacional o locus para tutela de tais direitos mas, também, que passa a influenciar diretamente as ordens internas com este referencial valorativo de proteção.

Uma vez consolidado o sistema internacional a partir do surgimento de organizações internacionais nas esferas global e regional, as quais têm uma função de monitoramento e prevenção de violações, como é o exemplo do sistema das Nações Unidas, pautado nos órgãos de monitoramento previstos nos grandes tratados sobre o tema. Mostram-se, também, importantes mecanismos capazes de atestar a responsabilidade do Estados por violações das normas positivadas em tratados. De acordo com Flávia Piovesan, na obra Direitos humanos e o direito constitucional internacional (2006), a obrigação de reparar juridicamente as violações de direitos humanos nasce com tribunais penais como o de Nuremberg, que assim como os tribunais da Ex-Iugoslávia, em 1993, e o de Ruanda, em 1994 e, atualmente o Tribunal Penal Internacional, possuem a atuação voltada para a justiça penal internacional, além de seu objeto ser a responsabilização penal de indivíduos que cometem crimes contra a humanidade.

No que tange à responsabilização internacional do Estado o papel dos sistemas regionais se mostra um importante termômetro para indicar a compatibilidade tanto legislativa quanto jurisprudencial e, também, de criação de políticas públicas internas, as quais fazem parte do diálogo dos Estados com os sistemas de Direitos Humanos, conforme determinado 
pelo Constituinte. Assim, a atuação dos dois organismos principais do sistema, quais sejam, quais sejam, Comissão e Corte, cada qual cumpre seu papel de, sobretudo, fazer valer o Pacto de San José da Costa Rica.

A compreensão de que o sistema internacional também prevê o monitoramento e a responsabilização dos Estados e que há abertura destes sujeitos de direito internacional para o sistema externo, nos indica que não cabe mais uma interpretação nacionalista dos direitos humanos.

Neste sentido, pergunta-se: como contribuir para que esta mudança de paradigma seja um processo contínuo e progressivo?

Esta pergunta impõe um desafio e uma reflexão para todas as pessoas que se dedicam ao trabalho com os direitos humanos. No entanto, partindo do pressuposto que a educação em direitos possui a potencialidade de incutir mudanças tantos globais quanto locais, o ensino jurídico deve ter um lugar de destaque neste contexto.

Em Pedagogia da autonomia saberes necessários à prática educativa, Paulo Freire (1996, p.17) nos ensina que a reflexão crítica da prática é a chave para evolução das ações futuras. Certo que a base para a reflexão crítica vem da teoria, ele defende que o discurso teórico deve ser concreto a ponto de se confundir com a prática, ao indicar que:

O seu "distanciamento" epistemológico da prática enquanto objeto de sua análise, deve dela "aproximá-lo" ao máximo. Quanto melhor faça esta operação tanto mais inteligência ganha da prática em análise e maior comunicabilidade exerce em torno da superação da ingenuidade pela rigorosidade. Por outro lado, quanto mais me assumo como estou sendo e percebo a ou as razões de ser de porque estou sendo assim, mais me torno capaz de mudar, de promover-me, no caso, do estado de curiosidade ingênua para o de curiosidade epistemológica. Não é possível a assunção que o sujeito faz de si numa certa forma de estar sendo sem a disponibilidade para mudar. Para mudar e de cujo processo se faz necessariamente sujeito também.

Transpondo as lições de Paulo Freire para o ensino jurídico a tarefa os docentes é possibilitar o contato desde cedo com o estudo da prática dos direitos humanos, aqui representados pelos casos analisados pelos tribunais internacionais bem como recomendações feitas por organizações internacionais. Tentando cumprir este objetivo é que a disciplina de Prática de Direitos Humanos se insere neste contexto como sendo uma peça essencial na formação dos estudantes de Direito.

Assim, este livro reúne a análise feita por graduandas e graduandos dos $5^{\circ}$ e $6^{\circ}$ períodos do curso de Direito da Pontifícia Universidade Católica de Campinas, de casos envolvendo o Brasil nos sistemas regional e global de direitos humanos, bem como a atuação 
de tribunais internos (em especial o STF). Ressalta-se que os trabalhos foram elaborados durante a pandemia do Covid-19 em 2020, o que potencializou o desafio de alunas e alunos ao longo do processo, pois, a pesquisa por materiais que embasassem ficou mais dificultosa em razão da restrição de acesso à biblioteca da faculdade entre outros motivos, como adaptação à nova realidade de aprendizagem à distância.

O livro pode ser dividido em duas partes. $\mathrm{Na}$ primeira, são analisados casos que chegaram ao Supremo Tribunal Federal e contribuíram para a formação de uma jurisprudência local sobre temas sensíveis de direitos humanos. São eles: mulheres transexuais em presídios, política de cotas raciais, aplicação do estatuto da pessoa com deficiência e, por fim, a análise do famoso caso Ellwanger. Na segunda parte, após a análise das regras gerais do sistema interamericano de direitos humanos, foram abordados os casos da senhora Maria da Penha, Gomes Lund e outros, Povo Indígena Xucuru e, por fim, o Complexo Penitenciário de Pedrinhas. Todos os casos envolvem o Brasil e possuem uma repercussão importante nos sistemas local e internacional, de modo que a análise por alunas e alunos de graduação de Direito mostra-se fundamental.

O objetivo de reunir os trabalhos em um livro se deu em razão da qualidade do resultado final destes que o leitor ou leitora poderá constar por si só, e, também, para servir de um material importante de consulta aos estudantes de direito ou a quaisquer pessoas que tenham especial apreço pela temática dos direitos humanos.

\footnotetext{
${ }^{1}$ Graduada, Mestre e Doutoranda em Direito, Professora de Direito Internacional Privadoe Comércio Internacional na Pontifícia Universidade Católica de Campinas, como também de Práticas Jurídicas em Direitos Humanos. Onde surgiu a idealização da presente obra. http://lattes.cnpq.br/8581083998215935.
} 


\section{SUMÁRIO}

CAPÍTULO 1 - MULHERES TRANSEXUAIS EM PRESÍDIOS: UMA ANÁLISE CRÍTICA.................................................................................12

Ana Clara Abreu Pacheco Geórgia Vasconcelos Ferfoglia Iasmin Cortes Palotta Julia Tavernari

Leonardo Vergani Amos $\underline{\text { Livia da Matta }}$ Maria Eduarda Ferreira Maria Eduarda Miranda

CAPÍTULO 2 - POLÍTICA DE COTAS RACIAIS: UMA ANÁlisE NO CONTEXTO

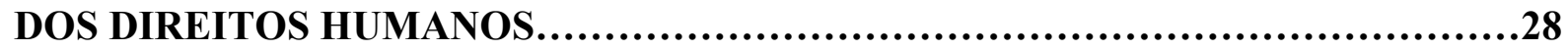

Camila De Sobral Mourato Gabriela Gabaldi Ferreira $\underline{\text { Leticia Costa De Miranda }}$ Mayara Gomes Dos Santos Mirlei Teixeira Morais

CAPÍTULO 3 - ANÁLISE SOBRE O ESTATUTO DA PESSOA COM DEFICIÊNCIA SOB A PERSPECTIVA DO STF. 38

Giovanna Baldan Isabela Bartholo Cesar

CAPÍTULO 4 - UMA ANÁLISE SOBRE O CASO ELLWANGER. .52

Ana Paula Almeida Franco Beatriz de Lima Brigato Gabriela Gomes de Oliveira Gabriela Paz Cassan Gabriela Rodrigues dos Santos Giulia Legaz Morais Leonardo Rosa Sestari Lívia Chechinato Raphael Marchi Livia Grandini Novaes $\underline{\text { Luiz Otávio Ferreira Pires }}$

CAPÍTULO 5 - NOÇÕES GERAIS DO SISTEMA INTERAMERICANO. .68

Giovanna Baldan Pedro Augusto de Castro Simbera Carolina Piccolotto Galib 
CAPÍTULO 6 - LEI MARIA DA PENHA: UM PANORAMA DA CORTE INTERNACIONAL ÀS MUDANÇAS ATUAIS. . .76

Beatriz Amorim Borelli Muniz Murilo Mendes Latorre Soares

CAPÍTULO 7 - ANÁliSE dA CONDENAÇÃO DO BRASIL PERANTE A CORTE INTERAMERICANA DE DIREITOS HUMANOS NO CASO GOMES LUND E OUTROS. .84

Pedro Augusto De Castro Simbera Carla Letícia Di Tullio Martins Gabriella Teixeira Campos Gabriel Freire Approbato Isabela Arruda Monteiro $\underline{\text { Yngrid Magrin }}$

CAPÍTULO 8 - CASO DO POVO INDÍGENA XUCURU .100

Gustavo Fernandes Poli

Leonardo Guardia Drago Rafael Kutkiewicz Fernandes Vinícius De Mello Bustamante $\underline{\text { Vitor Bianco Sartori }}$

CAPÍTULO 9 - ANÁlISE DO CASO JULGADO PELA CORTE INTERAMERICANA DE DIREITOS HUMANOS: COMPLEXO PENITENCIÁRIO DE PEDRINHAS. . .119

Guilherme Braga Herrera Guilherme Borsatto Haroldo Freitas Pires De Saboia Filho João Pedro Da Rocha Alonso Letícia Teixeira Pedrosa Yolanda Tavaniello De Julio $\underline{\text { Yago Diniz }}$

PREFÁCIO. 135

SOBRE OS ORGANIZADORES 137 



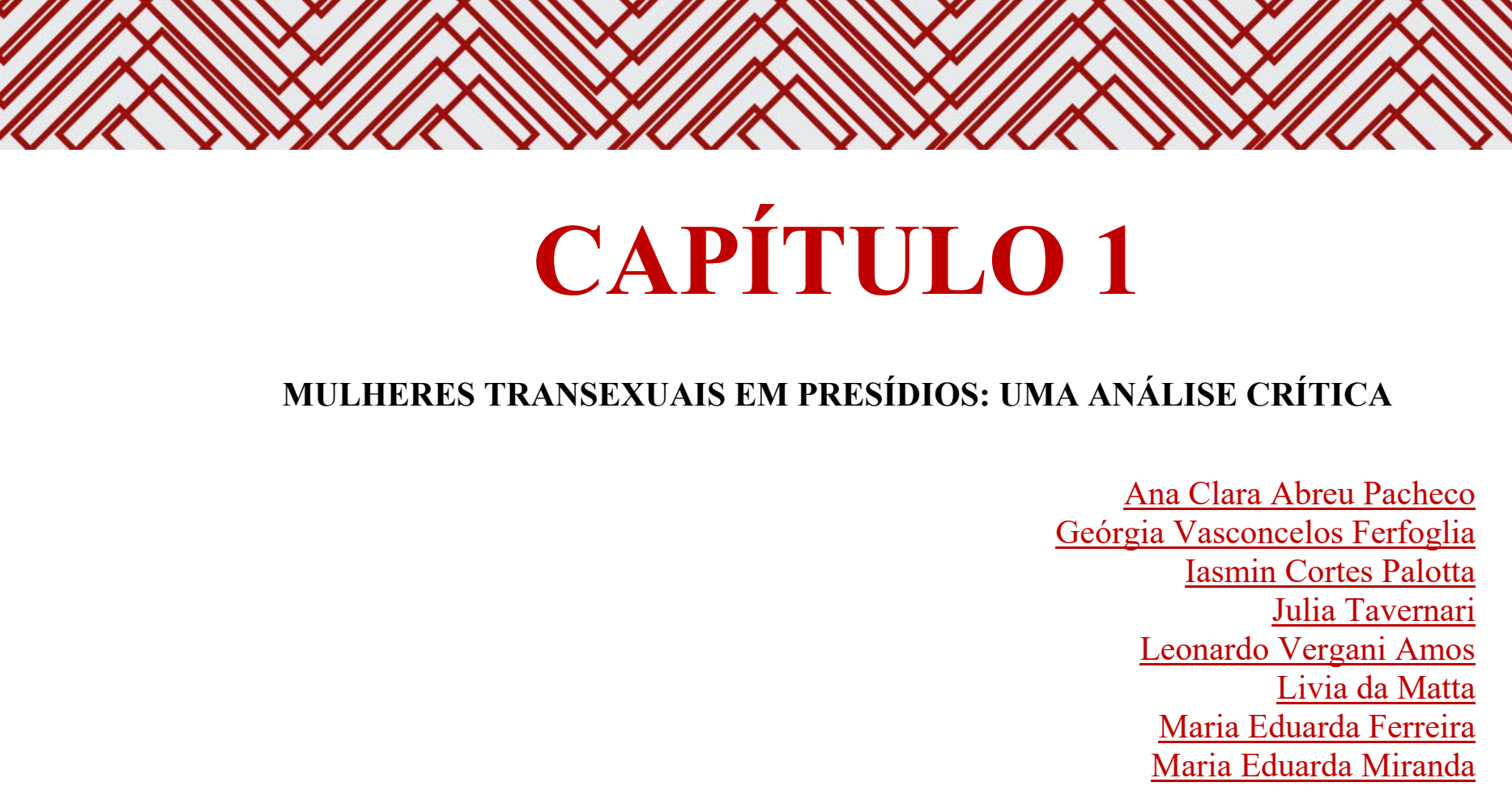

\section{INTRODUÇÃO}

\section{CONCEITO E BREVE HISTÓRICO}

Inicialmente, é necessário que haja a compreensão da transexualidade nos dias atuais e o processo histórico pelo qual essa parcela da população passou para ter seus direitos reconhecidos. A transexualidade caracteriza-se como uma identidade de gênero, na qual não há ligação causal com a orientação sexual como afirma a filósofa estadunidense Judith Butler.

É importante que tal conceito não se confunda com o de "transexualismo", visto que esta caracteriza a realidade de muitas pessoas como patologia, anteriormente diagnosticada cientificamente e enquadrada no Código Internacional de Doenças (CID 10, F.64), identificando-o como transtorno de identidade sexual. Entretanto, a Organização Mundial da Saúde (OMS) anunciou em 2018 a retirada deste como transtorno, de modo a determiná-la como uma incongruência de gênero, sendo assim, afirmando que é preciso que seja garantido atendimento às demandas específicas e de saúde da população trans.

$\mathrm{Na}$ transexualidade não há a identificação do indivíduo com seu sexo biológico, ou seja, a pessoa não possui uma identificação psicológica com o sexo nascença, ademais não necessita de cirurgia de readequação sexual e/ou terapia hormonal para se sentir como tal. Neste presente trabalho, para fins de melhor entendimento e aprofundamento do assunto, trataremos sobre as mulheres trans no sistema prisional brasileiro, buscando demonstrar as condições a que essa parcela da população está sujeita, por meio de dados e depoimentos obtidos através de relatórios e outros estudos realizados acerca do tema; num segundo momento, fez-se uma análise da legislação presente no Brasil aplicável ao objeto da presente pesquisa, culminando numa comparação crítica entre o plano formal e a realidade concreta. 


\section{GÊNERO, VIOLÊNCIA E ATUALIDADE}

Como já se sabe, a violência de gênero se apresenta de forma contínua, ocorrendo durante todas as fases do processo judicial e, inclusive, muito antes dele se iniciar. Ademais, manifesta-se em diversas modalidades, quais sejam, física, psicológica e principalmente institucional, uma vez que os órgãos responsáveis pela garantia dos direitos fundamentais, além de não zelarem pelos direitos da mulher, atuam como um dos maiores violadores desses, seja por ação ou omissão.

Tal afirmativa justifica-se, por exemplo, pela inobservância das peculiaridades e necessidades biológicas no âmbito prisional. É nítido que as prisões foram projetadas por homens e para homens. Além das condições de infraestrutura, o Estado é negligente quanto às condições básicas e inerentes ao corpo feminino. Nesse sentido é a experiência retratada pela jornalista Nana Queiroz em seu livro Presos que Menstruam, que revela a degradante situação a que as mulheres no Estado de São Paulo estão sujeitas. Sob a óptica das mulheres transexuais, esse quesito é agravado, uma vez que além do preconceito enraizado, sofrem com a indiferença de gênero. $O$ conceito de isonomia, nesse caso, deve ser interpretado de forma contra majoritária, isto é, compreender que os iguais devem ser tratados igualmente, bem como os desiguais desigualmente, levando em conta as suas peculiaridades.

Entende-se, nesse aspecto, que nossa Carta Política de 1988 é constantemente violada, pois dela se extrai que o único direito a que as sentenciadas deveriam estar restritas é a liberdade, contudo, na prática ocorre uma afronta direta ao Princípio da Dignidade Humana, formalmente tutelado em nosso Estado Democrático de Direito e inerente aos indivíduos em todas as suas esferas.

\section{VIOLÊNCIA}

Como é sabido a violência contra as mulheres transsexuais no Brasil é antiga e fortalece os padrões de comportamento que fundaram os estereótipos socioculturais e morais brasileiros, os quais refletem na vida não só destas, mas de todas as minorias sociais. Sendo assim, tal violência não pode ser entendida como uma ocorrência de significado pessoal, isto é, particular e exclusivo de uma pessoa, haja vista que ela não começa e tampouco termina num ato violento de um sujeito isolado, mas fundamentalmente trata-se de um efeito das estruturas das relações de poder e opressão de gênero.

A organização não governamental europeia Transgender Europe (TGEU) mantém um programa de monitoramento sistemático dos assassinatos de transsexuais, e a partir de relatos, 
boletins de ocorrência, apontam o alto índice de mortalidade desta população, especialmente no Brasil. É imprescindível pontuar que muitos trans morrem inviabilizados, uma vez que não constam nos boletins, nas estatísticas ou não são reconhecidos pelas suas famílias, tendo seus corpos muitas vezes enterrados como indigentes.

Os altos índices de violência física apontam que o Brasil é um país extremamente cruel com a comunidade transexual, seja em sociedade ou no ambiente carcerário, prova disto é o caso de Verônica Bolina, mulher transexual e negra, que antes de ser diagnosticada como portadora de transtorno mental foi presa após agredir uma vizinha e em seguida levada a uma carceragem masculina. Lá, após arrancar parte da orelha de um carcereiro com uma mordida, foi brutalmente agredida por policiais, foi despida, colocada no chão, seu cabelo foi raspado, algemada pelos pés, mãos e fotografada. As imagens se espalharam pelas redes sociais e se tornaram um símbolo da violência do Estado contra as mulheres trans.

Pierre Bourdieu (2016 apud MORAES, 2016, p. 1) traz como conceito de violência simbólica aquela que age silenciosamente. Muitas vezes, esse tipo de violência não faz parte de dados e pesquisas e, portanto, não se mostra tão aparente na sociedade como a violência física, mas está presente de modo tão frequente e dominante, que acaba colocando a comunidade trans às margens da sociedade civil.

A violência institucional é exemplo deste preconceito indireto e parte do próprio sistema. Para a redesignação de sexo (transgenitalização), por exemplo, o paciente deve se submeter a um acompanhamento de dois anos junto a uma equipe formada por psiquiatra, cirurgião, psicólogo e assistente social, para que a partir de um atestado de que não é portador de desvio psicológico permanente de identidade sexual, com rejeição do fenótipo, com tendência à automutilação ou ao autoextermínio, o paciente possa realizar a cirurgia.

Outro exemplo da violência simbólica no âmbito institucional é a dificuldade da mulher trans em garantir que seus direitos sejam equiparados ao da mulher cis. Hoje, por força do Enunciado 46 do Fórum Nacional de Juízes de Violência Doméstica e Familiar Contra a Mulher (FONAVID), a Lei Maria da Penha deve ser aplicada igualmente às mulheres trans, independentemente, inclusive, de alteração do nome de registro e da realização da redesignação sexual. O que ocorre na prática, entretanto, é a negativa da aplicação não só da Lei Maria da Penha, mas da categoria do feminicídio para as mulheres trans. 


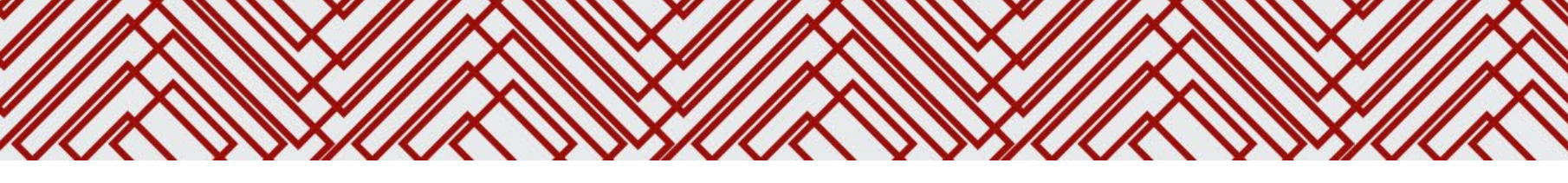

A situação se agrava muito quando analisamos a situação dos presídios brasileiros, tema que abordaremos mais a fundo ao longo do trabalho.

Outro modelo de violência a ser citado é a social, a qual é instaurada na vida das mulheres transexuais desde seu nascimento. A sociedade molda-se em uma definição binária de sexos (feminino e masculino), e desde o instante que a pessoa nasce lhe é atribuído o gênero (homem e mulher), destinando-lhe a forma de viver, vestir, portar e sentir. A partir do momento que esta pessoa vai crescendo e passa a exteriorizar sua disforia de gênero, os obstáculos tornam-se maiores e mais frequentes e, assim, seus relacionamentos passam a ser afetados, e a mulher acaba se tornando vítima de preconceito em seu ambiente escolar, profissional, familiar.

Em vista disso, percebe-se que as mulheres transsexuais sofrem marginalizações múltiplas ao longo da vida, muitas vezes sem recursos, nem sequer com família para que possa ter um suporte e restam mais uma vez à margem do Estado. É possível, ainda, dizer que a prostituição serve como uma válvula de escape movida pela necessidade de sobreviver dentro de uma sociedade capitalista. Dado que a grande maioria das mulheres transsexuais se encontram no mundo da prostituição, refere-se involuntariamente, em consequência disso, a imagem de trans à promiscuidade, colaborando cada vez mais para sua opressão.

É possível abordar todas as violências, das quais nos aprofundamos em algumas, sob o ponto de vista da violência psicológica, nesse sentido, há estudos no sentido de indicar tal violência como a base da agressão física, bem como o estágio inicial do desencadeamento das violências silenciosas, mostrando ser, de todo modo, a violência mais simbólica e presente na estrutura da sociedade brasileira, marcada por atitudes e posições historicamente empregadas a cada gênero. Segundo Bourdieu (2016 apud MORAES, 2016, p. 1) é a "violência suave, insensível, invisível as suas próprias vítimas, que se exerce essencialmente pelas vias puramente simbólicas da comunicação e do conhecimento, ou, mais precisamente, do desconhecimento, do reconhecimento, ou, em última instância, do sentimento".

\section{TRANSEXUAIS E OS PRESÍDIOS}

No campo de direito penal, ao cometer um delito, a mulher transexual é encaminhada pelo Estado a cumprir pena em uma penitenciária masculina. Esse encaminhamento é o início das inúmeras violações das mulheres transexuais quanto aos seus direitos fundamentais, considerando a inexistência de um tratamento adequado à sua identidade de gênero. 


\section{ESTATÍSTICAS}

A respeito do tema aqui tratado, serão evidenciados, em sua maioria, dados estatísticos que se mostram recentes, fato que auxilia a compreensão mais realista acerca do tema. Ademais, alguns outros levantamentos utilizados no presente estudo não se configuram como tão atuais, mas contribuem, igualmente, para o entendimento do cenário contemporâneo vivenciado por transexuais em presídios brasileiros, uma vez que o assunto ainda sofre com a carência de pesquisas.

Preliminarmente, vale salientar que de acordo com o Levantamento Nacional de Informações Penitenciárias, realizado em dezembro de 2017 pelo Departamento Penitenciário Nacional (DEPEN), o Brasil possui a terceira maior população carcerária do mundo, cenário que conta com, pelo menos, 726 mil pessoas encarceradas. O mesmo estudo feito pelo DEPEN também afirmou que $89 \%$ desses detentos se encontram em unidades superlotadas.

Nesta linha, é importante destacar o porquê de transexuais estarem no regime prisional brasileiro: no início do mês de Março desse ano (2020), o médico Drauzio Varella apresentou um quadro no Fantástico, programa exibido pela Rede Globo, que revelou uma estatística geral do Ministério da Mulher, da Família e dos Direitos Humanos sobre as presidiárias trans, a qual aponta que $38,5 \%$ estão presas por roubo, $34,6 \%$ por tráfico, $15,4 \%$ por furto, $7,7 \%$ por homicídio e 3,8\% por associação para o tráfico.

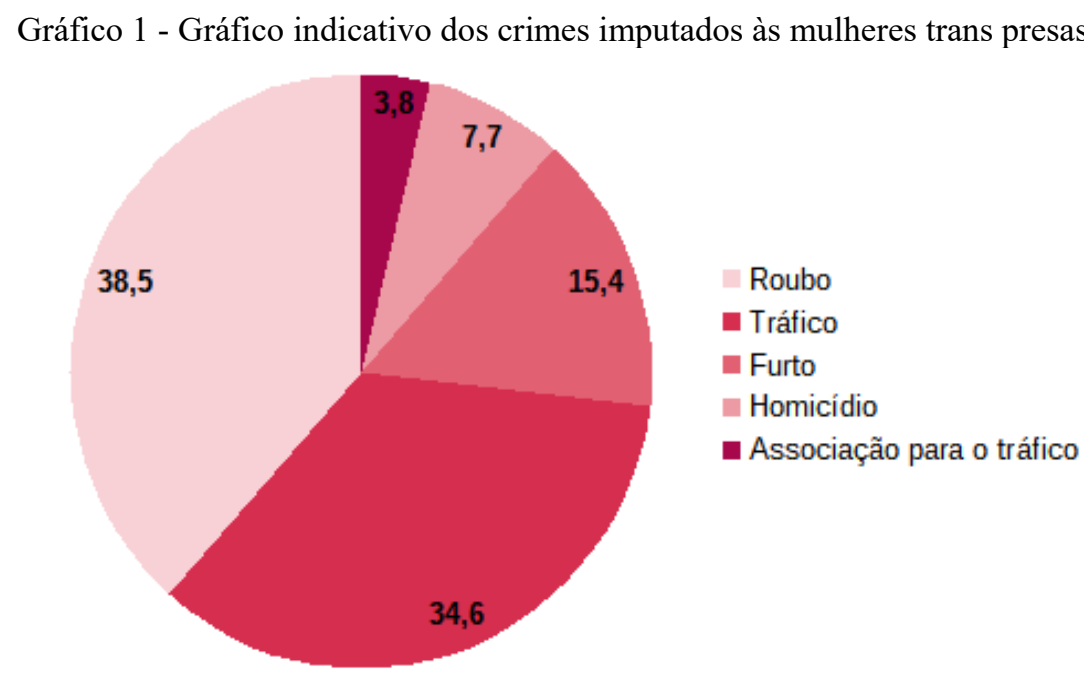

Fonte: https://g1.globo.com/fantastico/noticia/2020/03/08/nota-sobre-a-reportagem-que-mostrava-mulherestrans-em-presidios-brasileiros.ghtml 
Em seguida cumpre dizer que pela primeira vez o Governo Federal encomendou um estudo acerca do assunto $^{2}$, o qual confirma que transexuais estão entre os mais vulneráveis aos efeitos da precariedade do sistema prisional do Brasil. A referida pesquisa foi publicada na data de 5 de fevereiro de 2020 e reforçou um dado já sabido, qual seja, que travestis e transexuais sofrem constantemente com violências das mais diversas espécies dentro das prisões masculinas: emocionais, físicas, sexuais, além da prática de torturas específicas por sua condição de gênero.

Nessa perspectiva, o relatório "LGBT nas prisões do Brasil: Diagnóstico dos procedimentos institucionais e experiências de encarceramento" confirmou ser uma prática corriqueira, nos presídios masculinos, que mulheres trans sejam tratadas como homens, as quais, por muitas vezes, são forçadas a cortar o cabelo e usar roupas que não lhe agradam, além de não terem o seu nome social respeitado. No mais, um dos pontos mais chocantes diz respeito ao fato de precisarem abandonar a terapia hormonal que fazem, devido ao cenário que lhes é imposto dentro da prisão. Gustavo Passos, coordenador do estudo supracitado, entrevistou 131 pessoas que se identificam como LGBT encarceradas em todo o país.

Figura 1 - Capa do estudo "LGBT nas prisões do Brasil: Diagnóstico dos procedimentos institucionais e experiências de encarceramento".

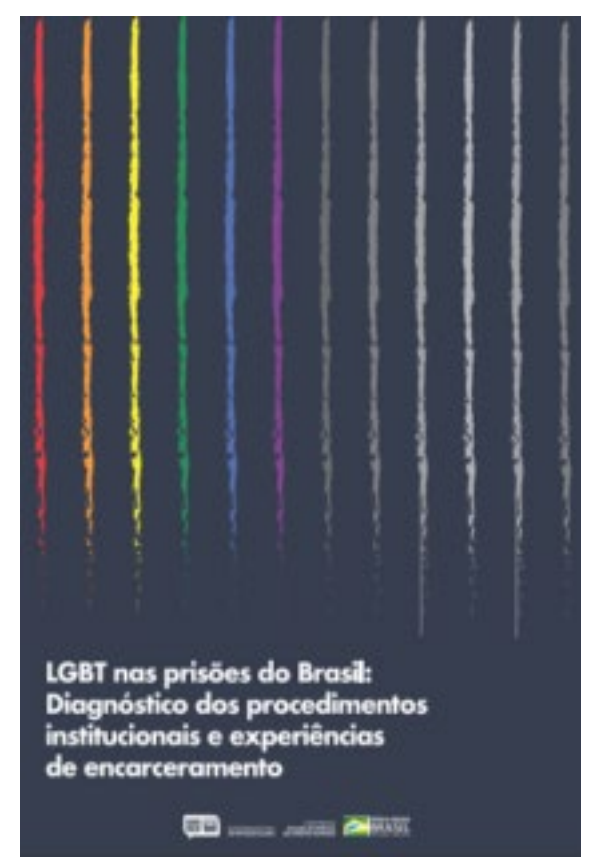

Fonte: https://www.gov.br/mdh/pt-br/assuntos/noticias/2020-2/fevereiro/TratamentopenaldepessoasLGBT.pdf

\footnotetext{
2"LGBT nas prisões do Brasil: Diagnóstico dos procedimentos institucionais e experiências de encarceramento", o documento (relatório) é uma iniciativa da Secretaria Nacional de Proteção Global (SNPG).
} 
questionamentos relativos à identidade de gênero e da orientação sexual dos que forem entrevistados, com o escopo de balizar a implementação de políticas públicas direcionadas especificamente aos LGBTI no Brasil, em especial para os trans.

Corroborando com o que fora exposto, torna-se viável relatar que as palavras-chaves procuradas para realizar pesquisas no Google Notícias e em páginas de plantões policiais são, comumente: "Travesti”, “Transexual”, "Morte”, “Assassinato" e "Agressão", adicionando-se a data do dia da busca. No entanto, pesquisadores perceberam que ao se buscar por substantivos, adjetivos e pronomes no gênero feminino, não se encontravam notícias, mas somente quando se buscava com a inclusão do artigo "o". E, ainda, o número de notícias aumentava se fossem utilizados termos como "traveco" e "homens que utilizavam vestimentas de mulher", o que escancara a forma pejorativa com que essas pessoas são tratadas pela mídia e pela própria sociedade em que estão inseridas. Conseguintemente, além de nem sempre serem veiculadas matérias jornalísticas sobre esse tema, quando os órgãos de comunicação decidem fazer, muitas vezes o fazem de maneira transfóbica, coisificando, vulgarizando e marginalizando as travestis e transexuais.

Para se obter maior compreensão acerca do tema e dos casos de violência em face da população transexual, segue abaixo dados relatados pela ONG Transgender Europe em relação aos homicídios referentes à prática de transfobia. Vale destacar que o referido estudo foi realizado entre os anos de 2008 e 2016.

Mapa 1 - Mapa da intolerância (países com mais registros de homicídios relacionados à transfobia entre 2008 e 2016).

\section{Intolerância}

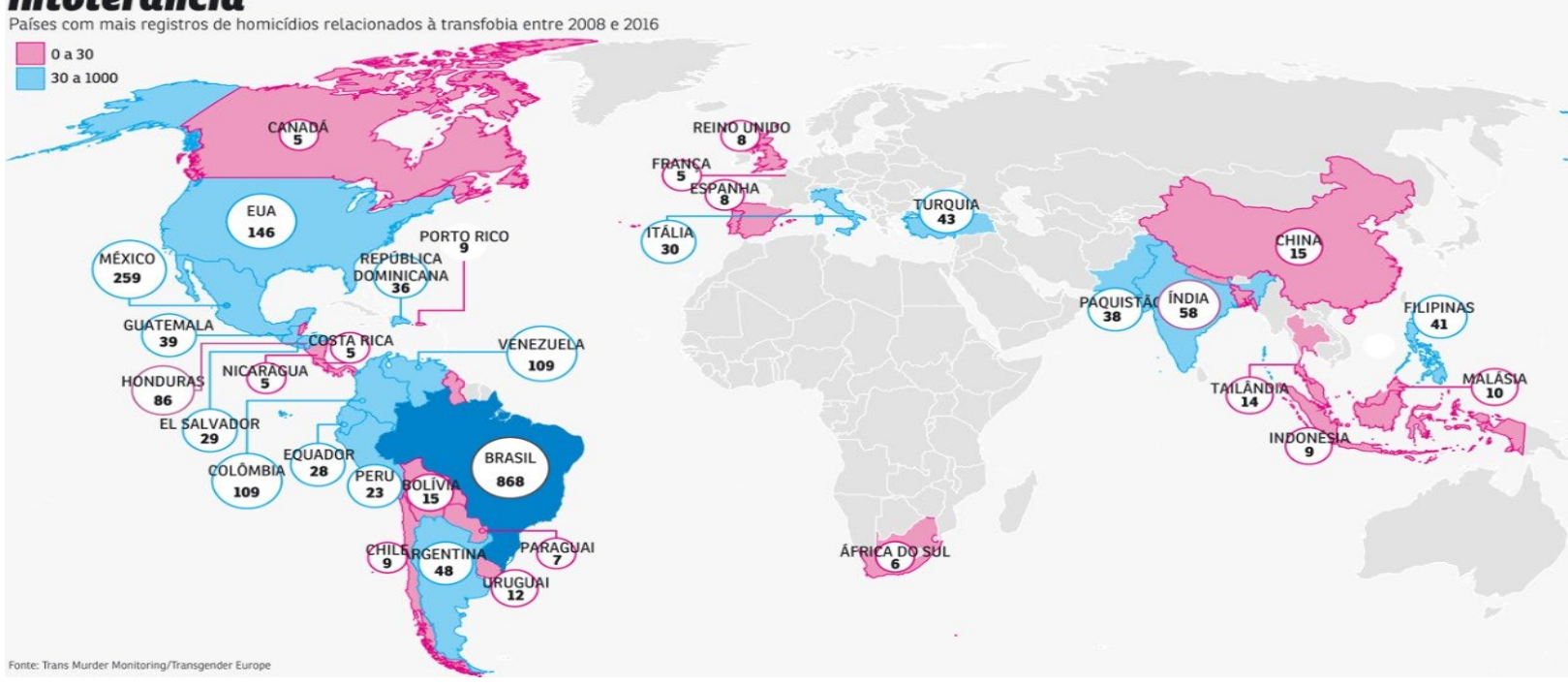

Fonte: Trans Murder Monitoring/Transgender Europe. 


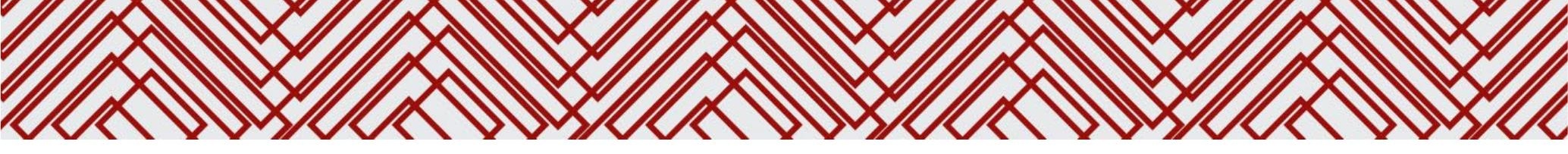

Tornando essa equação social mais complexa, adiciona-se o fato de que o suicídio é uma das causas mais recorrentes das mortes de mulheres e homens trans do Brasil nos últimos tempos. A maioria dos casos dizem respeito a jovens entre 15 e 29 anos, principalmente do gênero feminino. Ainda mais, um relatório do Núcleo de Direitos Humanos e Cidadania LGBT e do Departamento de Antropologia e Arqueologia, ambos da Universidade Federal de Minas Gerais, denominado “Transexualidades e Saúdes Públicas no Brasil”, apontou que $85,7 \%$ dos homens trans já pensaram ou tentaram cometer o suicídio. Dessa forma, é nítido que se trata de um sério problema de saúde pública nacional.

\section{LEGISLAÇÃO}

Apesar de não constar nos precedentes da Corte Interamericana de Direitos Humanos casos brasileiros de afronta aos direitos humanos de mulheres transexuais em presídios, podemos averiguar inúmeras ocorrências dessa natureza nos tribunais nacionais, como bem fora apontado no tópico anterior. O grande número de casos dessa espécie levou a organização de direitos humanos conhecida como Instituto Terra, Trabalho e Cidadania (ITTC), no ano de 2015, a fazer um relatório sobre "pessoas LGBTI privadas de liberdade no Brasil" com destinação ao Relator Especial do Conselho de Direitos Humanos da ONU sobre tortura e outros tratamentos ou punições cruéis, desumanos e degradantes, do Alto Comissariado dos Direitos Humanos das Nações Unidas.

Nesse relatório, averígua-se dados sobre o encarceramento no Brasil em que se destaca a superlotação e a seletividade do sistema de prisional brasileiro ${ }^{4}$, dados sobre a escassez de celas específicas para pessoas $\mathrm{LGBTI}^{5}$, a recente conquista do direito de "visitas" de casais homossexuais $^{6}$, e outros tantos dados relevantes. Uma das informações trazidas que mais chamam a atenção é a exposição de casos emblemáticos, dentre os quais podemos destacar o de Victoria Rios Strong:

O caso de Victoria Rios Strong, travesti presa em uma prisão masculina no estado de Minas Gerais foi uma das inspirações para a instalação da primeira ala para as pessoas LGBTI no Brasil. Em sua declaração: "Eu fui forçada a fazer sexo com

\footnotetext{
4“'De acordo com as informações disponibilizadas pelo Infopen (Informações Estatísticas do Sistema Prisional, elaborada pelo Ministério da Justiça), em 2014 o Brasil teve a quarta maior população carcerária em números absolutos e relativos. A taxa de superlotação das prisões brasileiras é a quinta maior, depois das Filipinas, Peru e Paquistão. [...] de acordo com o Infopen de 2014, aproximadamente $67 \%$ da população prisional é negra ou parda, 56\% está entre 18 e 29 anos e 53\% ainda não terminou o ensino fundamental" (SESTOKAS, 2015, p. 3).

${ }^{5}$ No ano de 2014 "apenas cerca de $15 \%$ dos estabelecimentos possuem celas especiais para idosos e para lésbicas, gays, bissexuais e transgêneros - LGBTI” (SESTOKAS, 2015, p. 6).

6“[ [...] em junho de 2011, após o Supremo Tribunal reconhecer a união estável homossexual em maio de 2011, o Conselho Nacional de Política Penal e Penitenciária emitiu um decreto $\left(n^{\circ} 4 / 2011\right)$ que estende o direito a visitas conjugais a casais homossexuais, direito já garantido a casais heterossexuais desde 1999" (SESTOKAS, 2015, p.7).
} 
todos os homens da cela em sequência. Todos eles rindo, zombando e me batendo. Fui ameaçada de morte se eu contasse aos agentes. Eu fui leiloada entre os prisioneiros. Um deles "me vendeu" em troca de 10 maços de cigarro, um suco e um pacote de biscoitos ". Victoria então começou a mutilar seus braços para chamar a atenção para sua situação. "Fiquei quieta até o dia em que não aguentei mais. Eu cheguei a sofrer 21 violações em um dia. Peguei hepatite e sífilis. Achei que eu ia morrer. Sem mencionar que eu tinha que fazer a limpeza da cela e lavar roupas de todos os homens. Eu era a primeira a acordar e a última a dormir ". A Coordenação da Diversidade Sexual do governo do estado de Minas Gerais descobriu que travestis são usadas como moeda de troca entre os prisioneiros e muitas pessoas evitam declarar sua homossexualidade dentro da prisão para evitar sofrer preconceito. (SESTOKAS, 2015, p. 5).

Malgrado esse e outros tantos relatos, o Brasil já dispõe de uma legislação que seguramente possui condições de determinar a adequação do sistema carcerário à população LGBTI, para tanto, podemos citar a Constituição da República Federativa do Brasil de 1988, que em seu artigo $3^{\circ}$, inciso $\mathrm{IV}^{7}$, estabelece como um de seus objetivos fundamentais a promoção do "bem de todos, sem preconceitos de origem, raça, sexo, cor, idade e quaisquer outras formas de discriminação". Do mesmo modo, seguindo o postulado da dignidade da pessoa humana, há a garantia constitucional do respeito à integridade física e moral da pessoa presa, nos termos do artigo $5^{\circ}$, inciso XLIX da Constituição ${ }^{8}$. Já a Convenção Americana de Direitos Humanos, por sua vez, determina que toda privação de liberdade deve respeitar a dignidade à pessoa humana (art. 5.2) ${ }^{9}$, bem como a proteção da honra (art. 11) ${ }^{10}$. Mais especificamente sobre as mulheres, defendemos a ideia de que a Convenção Interamericana para prevenir, punir e erradicar a violência contra mulher (Convenção de Belém do Pará) também pode ser aplicada às mulheres trans, uma vez que o artigo 1 desse documento internacional é claro ao estipular que "para os efeitos desta Convenção, entender-se-á por violência contra a mulher qualquer ato ou conduta baseada no gênero, que cause morte, dano ou sofrimento físico, sexual ou psicológico à mulher, tanto na esfera pública como na esfera privada" (grifo nosso). Neste sentido, deve-se lembrar que gênero não se confunde com sexo biológico, aquele, como fora mencionado outrora, diz respeito à maneira como a pessoa se enxerga e se sente, podendo ser homem, mulher, algo entre esses dois extremos do espectro, ou

\footnotetext{
${ }^{7}$ Art. $3^{\circ}$, IV, $\mathrm{CF} / 88$ : Constituem objetivos fundamentais da República Federativa do Brasil: IV - promover o bem de todos, sem preconceitos de origem, raça, sexo, cor, idade e quaisquer outras formas de discriminação.

${ }^{8}$ Art. 50 $5^{\circ}$ XLIX, CF/88: Todos são iguais perante a lei, sem distinção de qualquer natureza, garantindo-se aos brasileiros e aos estrangeiros residentes no País a inviolabilidade do direito à vida, à liberdade, à igualdade, à segurança e à propriedade, nos termos seguintes: XLIX - é assegurado aos presos o respeito à integridade física e moral.

${ }^{9}$ Art. 5.2, Convenção Americana de Direitos Humanos: Ninguém deve ser submetido a torturas, nem a penas ou tratos cruéis, desumanos ou degradantes. Toda pessoa privada da liberdade deve ser tratada com o respeito devido à dignidade inerente ao ser humano.

${ }^{10}$ Art. 11, Convenção Americana de Direitos Humanos: 11.1 - Toda pessoa tem direito ao respeito de sua honra e ao reconhecimento de sua dignidade; 11.2 - Ninguém pode ser objeto de ingerências arbitrárias ou abusivas em sua vida privada, na de sua família, em seu domicílio ou em sua correspondência, nem de ofensas ilegais à sua honra ou reputação; 11.3 - Toda pessoa tem direito à proteção da lei contra tais ingerências ou tais ofensas.
} 


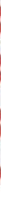

não se identificar com nenhum gênero; o sexo biológico, por sua vez, refere-se ao aspecto biológico da pessoa, seus cromossomos e genitália, podendo ser "classificada" como macho, fêmea ou intersexual. Por tanto, tendo em vista que o domínio de validade pessoal da Convenção de Belém do Pará incide nas pessoas que são do gênero mulher, não há motivos para segregar e excluir a mulher trans do rol de pessoas tuteladas por esse documento internacional; frisa-se que mulher trans é mulher.

Ainda no âmbito internacional, os princípios de Yogyakarta desempenham papel fundamental para a instrução da aplicação da legislação internacional de direitos humanos em relação à orientação sexual e identidade de gênero. Nesse sentido, esses conjuntos de princípios vão além de outros documentos internacionais, haja vista que não se limitam a estabelecer o direito, mas categoricamente exemplificam como cada Estado deve se adequar aquele determinado princípio, noutras palavras, apontam um caminho a ser seguido ao revés de limitar-se a estabelecer metafisicamente o direito. Como exemplo, tomemos o $9^{\circ}$ princípio de Yogyakarta (direito a tratamento humano durante a detenção); nele está disposto que:

Princípio 9: Toda pessoa privada da liberdade deve ser tratada com humanidade e com respeito pela dignidade inerente à pessoa humana. A orientação sexual e identidade de gênero são partes essenciais da dignidade de cada pessoa.

Logo em seguida aponta que os Estados deverão:

a) Garantir que a detenção evite uma maior marginalização das pessoas motivada pela orientação sexual ou identidade de gênero, expondo-as a risco de violência, maus-tratos ou abusos físicos, mentais ou sexuais;

b) Fornecer acesso adequado à atenção médica e ao aconselhamento apropriado às necessidades das pessoas sob custódia, reconhecendo qualquer necessidade especial relacionada à orientação sexual ou identidade de gênero, inclusive no que se refere à saúde reprodutiva, acesso à informação e terapia de HIV/Aids e acesso à terapia hormonal ou outro tipo de terapia, assim como a tratamentos de resignação de sexo/gênero, quando desejado;

c) Assegurar, na medida do possível, que todos os detentos e detentas participem de decisões relacionadas ao local de detenção adequado à sua orientação sexual e identidade de gênero;

d) Implantar medidas de proteção para todos os presos e presas vulneráveis à violência ou abuso por causa de sua orientação sexual, identidade ou expressão de gênero e assegurar, tanto quanto seja razoavelmente praticável, que essas medidas de proteção não impliquem maior restrição a seus direitos do que aquelas que já atingem a população prisional em geral;

e) Assegurar que as visitas conjugais, onde são permitidas, sejam concedidas na base de igualdade a todas as pessoas aprisionadas ou detidas, independente do gênero de sua parceira ou parceiro;

f) Proporcionar o monitoramento independente das instalações de detenção por parte do Estado e também por organizações não-governamentais, inclusive organizações que trabalhem nas áreas de orientação sexual e identidade de gênero;

g) Implantar programas de treinamento e conscientização, para o pessoal prisional e todas as outras pessoas do setor público e privado que estão envolvidas com as instalações prisionais, sobre os padrões internacionais de direitos humanos e princípios de igualdade e não-discriminação, inclusive em relação à orientação sexual e identidade de gênero. 


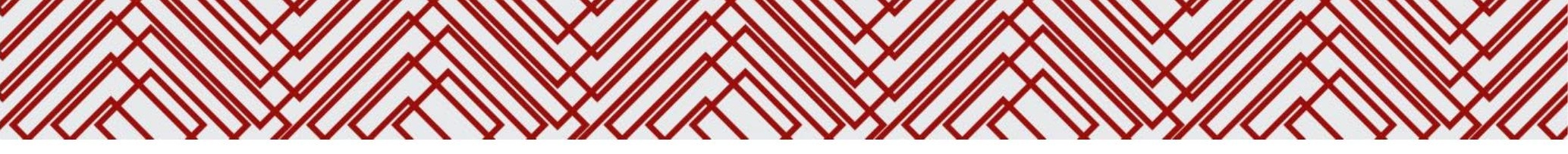

Percebe-se que essa maneira de tratar os direitos humanos contribui para superar a seguinte imperiosa questão apontada pelo jusfilósofo italiano Norberto Bobbio (2004, p. 16): "o problema fundamental em relação aos direitos do homem, hoje, não é tanto o de justificálos, mas o de protegê-los". O fato de um documento internacional apontar disposições a serem utilizadas pelo Estado que indiquem maneiras de proteger os direitos humanos, auxilia em grande medida o processo de densificação e concretização desses direitos.

Tratando-se de legislação mais específica no Brasil, temos a resolução conjunta $n^{0} 1$, de 15 de abril de 2014, proposta pelo Conselho Nacional de Combate à Discriminação e o Comitê Nacional de Política Criminal e Penitenciária, que trata das acomodações e tratamentos das mulheres trans e outros membros da comunidade LGBTI no sistema prisional. Nessa resolução, estabeleceu-se diversos direitos, como o da pessoa travesti ou transexual em privação de liberdade ser chamada pelo seu nome social, de acordo com o seu gênero (art. $2^{\circ}$ ); o direito de uso de roupas femininas ou masculinas, permanência de cabelos longos e outros caracteres secundários (art. $5^{\circ}$ ); a determinação de que pessoas transexuais masculinas e femininas devem ser encaminhadas para as unidades prisionais femininas (art. $4^{\circ}$ ), dentre outros direitos. Nada obstante, a precariedade desta resolução se torna exposta ao nos darmos conta de que:

\begin{abstract}
Não há sanções estabelecidas para a instituição prisional que não cumpre a resolução. Além disso, cabe a cada instituição implementar a resolução, com base nas condições de cada uma. Outra questão é que é preciso declarar-se LGBTI para acessar os direitos específicos estabelecidos. Embora isso possa parecer simples, ser abertamente gay, lésbica, transexual e/ou travesti no contexto da prisão significa colocar-se em situações vulneráveis, expondo-se tanto ao assédio dos agentes da prisão quanto ao dos outros prisioneiros. (SESTOKAS, 2015, p. 4).
\end{abstract}

Ainda no âmbito nacional, é importante fazer menção ao PL n.6350/2019 de autoria do deputado Marcelo Freixo - PSOL, cujo teor altera o $\S 1^{\circ}$ do art. 82 da Lei $n^{\circ} 7.210$, de 11 de julho de 1984 - Lei de Execução Penal ${ }^{11}$. Esse projeto de lei determina que além de mulheres e maiores de sessenta anos, travestis e transexuais masculina ou feminina deverão cumprir pena em estabelecimento próprio e adequado à sua condição social. É deveras perceptível a influência dos princípios de Yogyakarta nesse caso, ademais, é uma prova do caminho promissor aberto por documentos internacionais que estipulam maneiras/caminhos a serem seguidos pelo Estado na concretização de direitos humanos.

\footnotetext{
${ }^{11}$ Redação atual do $\S 1^{\circ}$ do art. 82 da Lei no 7.210 : “A mulher e o maior de sessenta anos, separadamente, serão recolhidos a estabelecimento próprio e adequado à sua condição pessoal”.
} 


\section{CONCLUSÃO}

Pelo exposto, conclui-se que malgrado a adoção de disposições legislativas protetivas da mulher trans e outros membros da comunidade LGBTI no sistema carcerário, a violência a esse grupo social ainda prevalece imponentemente. Ademais, infere-se que a proteção dos direitos fundamentais está diretamente ligada à igualdade contra majoritária, uma vez que tais mulheres possuem necessidades específicas, desconsideradas principalmente no ambiente prisional.

A sociedade contemporânea em que vivemos, diante da conjuntura de constante mutação social, é complexa e exige um olhar diferenciado sobre cada indivíduo. Desta forma, há que se valorizar cada cidadão em sua individualidade.

Tratando-se da realidade brasileira, conclui-se que o problema das várias formas de violência sofridas por mulheres trans nos presídios não está no plano formal, mas no plano material, uma vez que já possuímos legislação suficiente que garante um tratamento adequado às mulheres trans nos presídios, mas infelizmente não temos uma fiscalização adequada. Diante de tal situação, infere-se, outrossim, que o Estado pode ser entendido de forma dual, ora como garantidor de direitos, ora como extensão do preconceito e da violência humana, fato que vai plenamente de encontro com a própria concepção de Estado Democrático de Direito.

Por fim, cumpre lembrar a lição do grande jurisconsulto alemão Jhering (2015) de que a vida da lei é uma batalha; faz-se necessário uma indignação ao errado, a resistência ao injusto é o dever de todos que gozam das prerrogativas tuteladas pelo Direito.

\section{REFERÊNCIAS}

ANTRA. ANTRA oficia DPU e esta envia recomendação ao IBGE sobre a população trans no censo de 2020. Disponível em: https://antrabrasil.org/2018/05/16/antra-oficia-dpu-eesta-envia-recomendacao-ao-ibge-sobre-a-populacao-trans-no-censo-2020/. Acesso em: 4 mai. 2020.

BOBBIO, Norberto. A Era dos Direitos. 7. ed. Rio de Janeiro: Elsevier, 2004.

BRASIL. Constituição Federal de 1988. Senado Federal.

EXAME. Pesquisa inédita mapeia população LGBT e trans nos presídios paulistas. Disponível em: https://exame.abril.com.br/brasil/pesquisa-inedita-mapeia-populacao-lgbt-etrans-nos-presidios-paulistas/. Acesso em: 4 mai. 2020. 
FUNDAMENTAL À IDENTIDADE DE GÊNERO. Revista do Instituto do Direito brasileiro, 2013. Disponível em: Revista do instituto do direito brasileiro, 2013. Disponível em:http://www.cidp.pt/revistas/ridb/2013/03/2013_03_02337_02364.pdf. Acesso

em: 4 mai. 2020.

GÊNERO E NÚMERO. Violência contra mulheres trans e travestis começa em casa e continua do lado de fora. Disponível em: http://www.generonumero.media/maioria-deagressoes-mulheres-trans-e-travestis-ocorre-dentro-de-casa-revelam-dados-do-ministerio-dasaude/. Acesso em: 5 mai. 2020.

GLOBO. Estupro e tortura: relatório inédito do governo federal aponta o drama de trans encarceradas em presídios masculinos. Disponível em: https://g1.globo.com/cienciae-saude/noticia/2020/02/06/estupro-e-tortura-relatorio-inedito-do-governo-federal-aponta-odrama-de-trans-encarceradas-em-presidios-masculinos.ghtml. Acesso em: 5 mai. 2020.

Nota sobre a reportagem que mostrava mulheres trans em presídios brasileiros. Disponível em: https://g1.globo.com/fantastico/noticia/2020/03/08/nota-sobre-areportagem-que-mostrava-mulheres-trans-em-presidios-brasileiros.ghtml. Acesso em: 4 mai. 2020.

JHERING, Rudolph Von. A Luta Pelo Direito. 2. ed. [s. L]: Hunter Books, 2015.

LENZA, Pedro. Direito Constitucional esquematizado. 17. ed. São Paulo: Saraiva, 2013. p.1044.

LIMA, H. B.; RODRIGUES DO NASCIMENTO, R. V. TRANSGENERIDADE E CÁRCERE: DIÁLOGOS SOBRE UMA CRIMINOLOGIA TRANSFEMINISTA. Revista Transgressões, v. 2, n. 2, p. 75-89, 10 dez. 2014.

MIGALHAS. Mulheres transexuais e a indiferença de gênero no sistema carcerário. Disponível em: https:/www.migalhas.com.br/depeso/318114/mulheres-transexuais-e-aindiferenca-de-genero-no-sistema-carcerario. Acesso em: 5 mai. 2020.

MORAES, Renan Ribeiro de. Violência contra a mulher transgênero: Para além da agressão física. Disponível em: https://ambitojuridico.com.br/edicoes/revista-153/violenciacontra-a-mulher-transgenero-para-alem-da-agressao-fisica/. Acesso em: 4 mai. 2020.

ORGANIZAÇÃO DOS ESTADOS AMERICANOS. Convenção Americana de Direitos Humanos ("Pacto de San José de Costa Rica"), 1969.

ORGANIZAÇÃO DOS ESTADOS AMERICANOS. Convenção Interamericana para prevenir, punir e erradicar a violência contra mulher (“Convenção de Belém do Pará”), 1994.

PONTE. Verônica Bolina: como um caso de saúde mental virou caso de polícia. Disponível em: https://ponte.org/veronica-bolina-como-um-caso-de-saude-mental-virou-casode-policia/. Acesso em: 5 mai. 2020.

As armadilhas para quem pesquisa violência contra LGBT+ no Brasil. $\overline{\text { Disponível }} \mathrm{em}$ : https://ponte.org/pela-primeira-vez-atlas-da-violencia-traz-dados-sobrepopulacao-lgbti/. Acesso em: 4 mai. 2020. 
PRINCÍPIOS DE YOGYAKARTA: princípios sobre a aplicação da legislação internacional de direitos humanos em relação à orientação sexual e identidade de gênero. Disponível em: http://www.dhnet.org.br/direitos/sos/gays/principios_de_yogyakarta.pdf/. Acesso em: $15 \mathrm{de}$ julho de 2020.

QUEIROZ, Nana. Presos que menstruam. 1 ${ }^{\mathrm{a}}$ ed. Editora Record. São Paulo: 2015.

REVISTA PERIÓDICUS. Violência contra LGBTs: premissas históricas da violação no Brasil.

https://cienciasmedicasbiologicas.ufba.br/index.php/revistaperiodicus/article/view/28014/171 41. Acesso em: 3 mai. 2020.

ROCHA, M. V. D; SÁ, Itanieli Rotondo. TRANSSEXUALIDADE E O DIREITO TVBRASIL. Visibilidade Trans: entenda a transexualidade e o processo transexualizador. Youtube. Disponível em: https:/www.youtube.com/watch? $\mathrm{v}=\mathrm{kc} 7$ f52m9c/. Acesso em: 4 mai. 2020.

REDE TRANS. Dossiê: a geografia dos corpos das pessoas trans. Disponível em: http://redetransbrasil.org.br/wp-content/uploads/2019/01/A-Geografia-dos-Corpos-Trans.pdf/. Acesso em: 4 mai. 2020.

SESTOKAS, Lucia. Breve relatório sobre pessoas LGBTI privadas de liberdade no Brasil. ITTC: 2015. Disponível em: http://ittc.org.br/wp-content/uploads/2017/12/breverelatorio-sobre-pessoas-lgbt-privadas-de-liberdade-no-brasil.pdf. Acesso em: 1 mai. 2020.

UNAIDS BRASIL. OMS anuncia retirada dos transtornos de identidade de gênero de lista de saúde mental. Disponível em:https://unaids.org.br/2018/06/oms-anuncia-retiradados-transtornos-de-identidade-de-genero-de-lista-de-saude-mental/. Acesso em: 4 mai. 2020. 


\section{CAPÍTULO 2 \\ POLÍTICA DE COTAS RACIAIS: UMA ANÁLISE NO CONTEXTO DOS DIREITOS HUMANOS

\author{
Camila De Sobral Mourato \\ Gabriela Gabaldi Ferreira \\ Leticia Costa De Miranda \\ Mayara Gomes Dos Santos \\ Mirlei Teixeira Morais
}

\section{INTRODUÇÃO}

No Brasil, o debate acalorado que se forma em torno da temática da "Política de Cotas Raciais" ainda é objeto de muitas divergências e, inclusive, foi pauta do Supremo Tribunal Federal na ADPF 186. De um lado, o que se observa é um discurso meritocrático, pautado na superficialidade do princípio da igualdade formal. A outra face da questão, no entanto, revela a necessidade de medidas e ferramentas aptas à emancipação daqueles que nunca antes foram libertos do preconceito e das desigualdades sociais.

A criação das cotas raciais no Brasil se deu a partir de um cenário no qual mais da metade da população brasileira era formada por pessoas pretas ou pardas; no entanto, apenas uma pequena parcela deste grupo de pessoas ocupava cargos de alta remuneração ou frequentavam universidades. Este fato desvelou a existência de um racismo institucional, pois se tornou evidente a manutenção de mecanismos de discriminação sedimentados na operação do sistema social e que funcionavam, até certo ponto, à revelia da sociedade como um todo.

Em que pese o Brasil fosse signatário da Convenção para Eliminação de Todas as Formas de Discriminação Racial desde 1968, somente a partir de 2012, com a ADPF 186, é que medidas concretas começaram a ser tomadas, a fim de diminuir as disparidades econômicas, sociais e educacionais existentes entre pessoas de diferentes etnias raciais. Para tanto, foram criadas as leis 12.711/2012 e 12.990/2014, visando garantir a inclusão dos grupos sociais desprivilegiados nas universidades públicas e nos cargos públicos, através da destinação de cotas, ou seja, de uma determinada porcentagem das vagas às pessoas que a estes grupos pertencem, para promover, desta forma, uma convivência social diversificada, harmônica e, sobretudo, democrática.

A política de cotas raciais é, portanto, uma forma possível de colocar em práticas as ações afirmativas, definidas por Flávia Piovesan como 
(...) medidas especiais e temporárias que, buscando remediar um passado discriminatório, objetivam acelerar o processo com o alcance da igualdade substantiva por parte dos grupo socialmente vulneráveis, como as minorias étnicas e raciais, entre outros grupo (PIOVESAN, 2005).

Conforme será examinado neste trabalho, a existência de ações afirmativas - mais especificamente a política de cotas raciais - e, consequentemente, a sua aplicação efetiva são de extrema importância no processo de transformação da igualdade formal em igualdade material, a qual, verdadeiramente, preza por um ideal de justiça em uma sociedade que privilegiou, por tanto tempo, um grupo social em detrimento de outro.

Para fins demonstrativos de como as ações afirmativas são essenciais num processo de democratização dos espaços públicos, bem como na emancipação das minorias, o Instituto Brasileiro de Geografia e Estatística (IBGE), por meio do estudo Desigualdade Sociais por Cor ou Raça realizado no ano de 2018, constatou que, após a criação da lei 12.711/2012 e a consequente efetivação da política de cotas raciais, o número de negros e pardos nas universidades públicas passou a ser a maioria, com 50,3\%. Este fato demonstra um grande avanço para a sociedade brasileira na luta contra o racismo e a discriminação, pois é a partir da convivência diversificada e inclusiva - em que os negros, indígenas e pessoas de diversos grupos minoritários ocupem um lugar de representatividade social - que se faz possível a criação de uma atmosfera democrática, baseada no respeito, na empatia e, acima de tudo, na tão almejada igualdade material.

Por fim, como bem salienta Boaventura de Souza Santos,

(...) temos o direito a ser iguais quando a nossa diferença nos inferioriza; e temos o direito a ser diferentes quando a nossa igualdade nos descaracteriza. Daí a necessidade de uma igualdade que reconheça as diferenças e de uma diferença que não produza, alimente ou reproduza as desigualdades" (SANTOS, 2003).

\section{BREVE HISTÓRICO}

Antes de adentrar o tema, faz-se necessário, compreender o legado da escravidão enquanto constituinte da dinâmica social, política e econômica brasileira e seu papel determinante no fomento de diversos debates, no decorrer dos anos, acerca de políticas públicas, igualdade racial e ações afirmativas.

É notório que a escravidão atrelada à comercialização de povos africanos fruto do tráfico negreiro transatlântico no século XVI, findou-se em 1888, com o Brasil sendo o último país do ocidente a aboli-la, de forma que até esse momento o negro fora considerado, política, jurídica e ideologicamente, propriedade, isto é, não havia status de "humanidade", eram tidos, única e exclusivamente como, objetos, e não sujeito de direitos. 


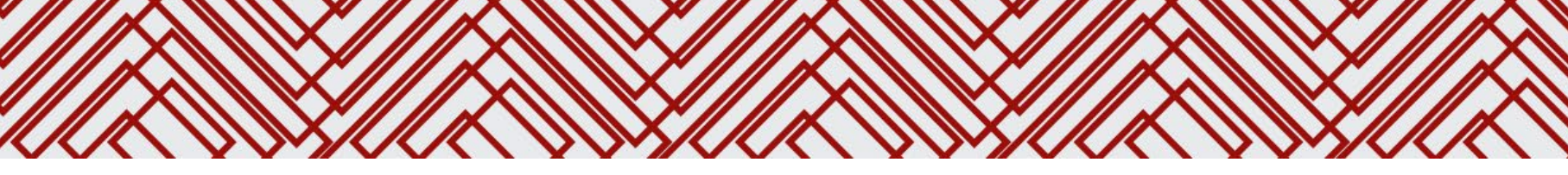

Com o advento da Lei Áurea, ocorre uma guinada e, o grande contingente de afrodescendentes que, antes, eram vistos como coisa, são alçados à condição de cidadãos, ainda que, a condição de discriminados se fizesse presente, haja vista as relações raciais já hierarquizadas.

Nada obstante, o país estivesse passando por grandes transformações, muito em virtude do processo de instauração da República (1889) que, no ponto de vista, ideológico era sinônimo de progresso, civilidade, avanço e povo homogêneo, nunca houve a intenção, desde aquele momento, de incorporação do negro, agora liberto, como parte desse novo regime. Isso, porque, a elite da época tinha nas políticas eugênicas a ferramenta necessária para a constituição desse povo brasileiro ideal - caucasiano europeu - e, ocasionalmente, solucionar questões de sanitarismo e urbanidade, extremamente precárias naquele período, sem considerar, entretanto, o fato de que o Brasil, desde seu descobrimento, se forjou na base da mistura de grupos sociais (miscigenação), e com a quantidade de africanos que aqui aportaram, a proporção de negros era maior, e sempre foi, do que de brancos. De modo, que era impossível empreender o processo de branqueamento almejado, pelo menos, não de forma orgânica.

Destarte, foram diversos os mecanismos desenvolvidos no transcorrer desses cinco séculos visando à exclusão da massa indesejada. Políticas de segregação urbana e racial. Oportuno ressaltar, por exemplo, a primeira lei de educação datada de 1837, que em seu artigo $3^{\circ}$, vedava "Os escravos, e os pretos Africanos, ainda que sejão livres ou libertos" ${ }^{12} \mathrm{de}$ frequentar escolas de ensino público, além da Lei de Terras (1850), que impedia o acesso e aquisição de terras por parte da população negra. Posteriormente, nos anos de 1871 e 1885 foram promulgadas, respectivamente, a Lei do Ventre Livre e a Lei do Sexagenário. Conforme a primeira, eram livres todos os filhos de mulheres escravas nascidos a partir daquela data, entretanto, as crianças acabavam no campo de trabalho, vez que, eram proibidas de frequentar escolas e áreas públicas, enquanto a segunda considerava livre quem alcançasse 60 anos, fato é que nenhum negro alcançava essa idade. Em que pese ambas, tivessem como propósito dar continuidade ao processo - lento e gradual - de abolição no país (tendência mundial desde 1823), ausentes foram os subsídios para que estes ex-escravos realmente conseguissem se restabelecer, pelo contrário, a implementação de subterfúgios de segregação nas décadas seguintes foram sistemáticas.

\footnotetext{
${ }^{12}$ Lei n. 1, de 1837, sobre Instrução Primária no Rio de Janeiro.
} 


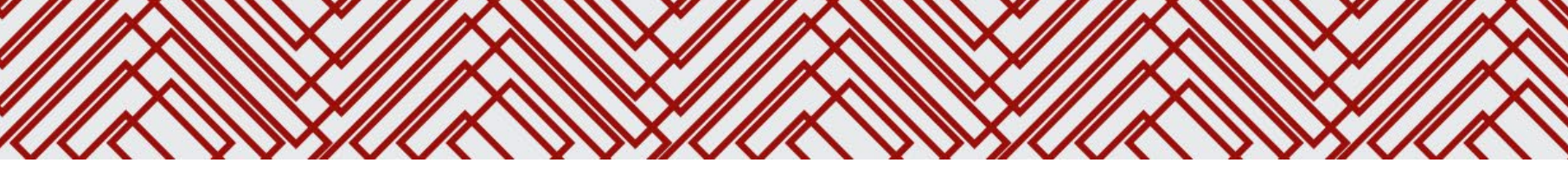

A política imigrantista de 1890, ilustra bem essa arranjo, projeto governamental de incentivo a imigração européia (alemães, italianos, espanhóis) visando suprir o déficit de mão de obra, porém capital humano não faltava, principalmente num momento emblemático de pós abolição onde havia um enorme contingente de ex-escravos desempregados e em situação miserável. E que, ainda, sim foram preteridos ante o imigrante no preenchimento desses postos, isso em um período onde os símbolos de riqueza e poder eram, justamente, terra e trabalho, e tudo isso aliado aos negros, na tentativa de apagar a herança escravocrata.

Outrossim, a "Lei da Vadiagem", igualmente de 1890, funcionou como mecanismo legal de controle de corpos, que criminalizava quem tinha habilidade para trabalhar e não tendo condições financeiras (patrimônio) para se manter, e que não trabalhando era punido com a detenção. E no contexto de 1870/1890, pessoa livre, com idade para trabalhar, que não trabalhava e que não tinha dinheiro para se manter era, justamente, a população negra liberta. É a partir desse momento, inclusive, que é dado início o processo de segregação socioespacial e encarceramento em massa dessa população.

Portanto, consistiram em políticas de Estado, políticas racistas e estruturais de pensar estratégias para dificultar, violar direitos e não permitir que alguns grupos tivessem acesso aos recursos, medidas concretas que impediram e precarizaram as condições de vida dos negros e seus descendentes, cujos reflexos, infelizmente, persistem hodiernamente, em todos os setores sociais.

\section{FUNDAMENTAÇÃO JURÍDICA}

Mesmo diante de um cenário onde uma grande luta dos negros pelo Direito de Igualdade - no sentido material, inclusive - se perpetua no tempo, hodiernamente as leis existentes no ordenamento jurídico brasileiro, que abordam o tema cotas raciais, não se mostram por si só suficientes para garantir tal igualdade, visto que na prática existem inúmeros obstáculos a serem superados, para isso basta analisar os estudos ${ }^{13}$ que mostram a quantidade de negros que ocupam as posições de discentes e docentes no âmbito acadêmico. Contudo vale destacar quando se deram o surgimento de algumas dessas leis, que abrangem o tema aqui examinado, no rol jurídico brasileiro.

\footnotetext{
${ }^{13}$ Disponível em: $\quad<$ https://www1.folha.uol.com.br/educacao/2019/12/na-usp-apenas-21-dos-mais-de-5000educadores-sao-pretos-ou-pardo.shtml >; $<$ https://g1.globo.com/educacao/noticia/2019/11/06/taxa-de-jovensnegros-no-ensino-superior-avanca-mas-ainda-e-metade-da-taxa-dos-brancos.ghtml $>$ Acessado em: 02, Abril, 2020 .
} 


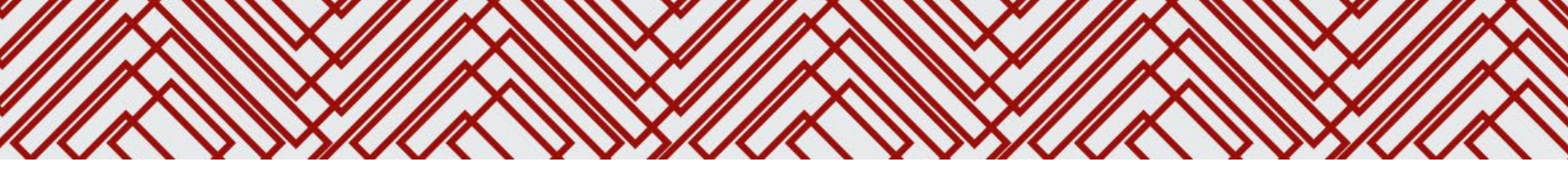

Em 09/11/2001 foi publicada a Lei no 3.708/2001 aprovada na Assembleia Legislativa do Rio de Janeiro a qual reservava $40 \%$ das vagas em instituições públicas para estudantes negros ou pardos, inaugurando a política de ações afirmativas ${ }^{14}$ no país.

No ano de 2002 a MP no 63/2002 foi votada no Congresso Nacional resultando na Lei $\mathrm{n}^{\mathrm{o}} 10.558 / 02$ que instituiu o programa Diversidade na Universidade, objetivando facilitar o acesso ao ensino superior para pessoas socialmente desfavorecidas, afrodescentes e indígenas.

A primeira universidade pública no Brasil a adotar o sistema de cotas raciais, reservando $20 \%$ de suas vagas aos negros, foi a UERJ, no ano de 2003 . E no ano seguinte a UnB implantou um sistema de cotas em seu vestibular, também reservando $20 \%$ das vagas para candidatos negros e um pequeno número para indígenas, tornando-se então a primeira instituição Federal a implantar uma política de ações afirmativas para negros no país. A partir de então houve intensos debates na sociedade sobre o tema de tal maneira que em 2010 foi proposta a ADPF 186 pelo partido do DEM que alegava a inconstitucionalidade do sistema de cotas raciais da UnB, mais tarde em 2012 a Suprema Corte brasileira decidiu, por unanimidade, pela constitucionalidade das cotas julgando improcedente a ação ajuizada pelo DEM.

Ainda em 2010 foi publicada a Lei $n^{\circ}$ 12.288/10 que institui o Estatuto da Igualdade Racial, "destinado a garantir à população negra a efetivação da igualdade de oportunidades, a defesa dos direitos étnicos individuais, coletivos e difusos e o combate à discriminação e às demais formas de intolerância étnica" ipsis litteris. Posteriormente o Decreto $\mathrm{n}^{\circ}$ 8.136/13 regulamentou o Sistema Nacional de Promoção da Igualdade Racial - Sinapir.

Seguindo nessa seara, passou a fazer parte do ordenamento jurídico brasileiro em 2012 a Lei $n^{0} 12.711 / 12$ conhecida como Lei de Cotas, esta por sua vez trouxe em seu texto a reserva de $50 \%$ das vagas dos cursos de graduação das Instituições Federais aos autodeclarados pretos, pardos e indígenas. Esta Lei foi regulamentada pelo Decreto $\mathrm{n}^{\mathrm{o}}$ 7.824/12. E por fim, em 2014 ingressa no ordenamento jurídico pátrio a Lei nº 12.990/14 que reserva $20 \%$ das vagas de concursos públicos para negros.

As Leis aqui apresentadas são apenas um rol exemplificativo do que há sobre o tema cotas raciais na legislação brasileira, mas que ainda assim é capaz de nos fazer compreender como estamos caminhando a passos lentos em relação ao tema aqui abordado, pois o Brasil

\footnotetext{
${ }^{14}$ Entende-se por ações afirmativas o conjunto de medidas especiais voltadas a grupos discriminados e vitimados pela exclusão social ocorridos no passado ou no presente.
} 
ainda se mostra uma nação com grandes dificuldades para garantir a efetividade do direito de igualdade aclamado pela população negra. Dificuldades estas de cunho diversos, como por exemplo, projeto de lei existente no Congresso Nacional que colide com o que já foi sedimentado na legislação pátria. É o caso do PL 1531/2019 que prevê a alteração da Lei no 12.711/12 para extinguir o critério racial de reserva de vagas no ensino superior. Como se pode observar isso espelha alguns dos obstáculos que a população negra no Brasil precisa enfrentar para ter direito a ocupar posições que são naturalmente e sem objeções ocupadas por brancos, dentro de uma sociedade que se apresenta mais propensa a meritocracia do que a democracia.

\section{ARGUMENTOS FAVORÁVEIS À POLÍTICA DE COTAS RACIAIS}

Haja vista as análises supracitadas, a esfera das universidades apresenta grandes debates a respeito das cotas raciais, nos quais se discutem tantos os argumentos a favor, quanto os contras.

O primeiro argumento favorável às cotas raciais, tange ao redor da sociedade racista, a qual possui um longo histórico de escravidão e opressão negra. Desta forma, devido ao atraso de inserção dos afrodescendentes nos diversos ambientes coletivos, as oportunidades de estudo acabam sendo limitadas, consequentemente prolongando a discriminação.

No mais, ainda quanto os antecedentes históricos do Brasil, cabe frisar o papel do Estado em, contribuir com a equidade, ou seja, observar os requisitos de justiça para nivelar as oportunidades de educação, incluindo todos os brasileiros, independentemente de etnia, levando em consideração que a cor de pele foi utilizada diversas vezes como critério para suprimir os afrodescendentes.

Visando promover a equiparação supracitada, a Convenção sobre a Eliminação de Todas as Formas de Discriminação Racial incluiu em seu dispositivo legal medidas especiais e temporárias que incluem os negros tanto no trabalho, quanto nas universidades. A justificativa para a promoção da norma, que inclui as cotas raciais, transcorre a partir do objetivo principal: acelerar o processo de alcance da igualdade.

Haja vista o cenário financeiro atual, questão racial dentro economia brasileira pode ser elencada como outro argumento favorável às cotas, considerando que, de acordo com as pesquisas de censo os negros ainda ocupam a maior porcentagem de trabalhos considerados inferiores, os quais possuem baixa remuneração e nenhum perspectiva de crescimento. 


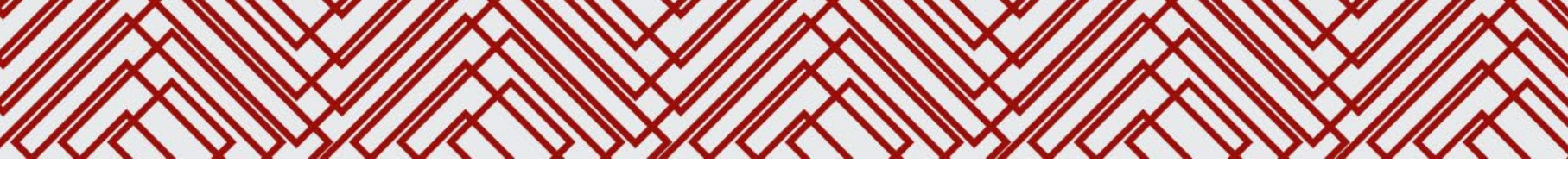

Indubitavelmente, as situações retratadas geram um ciclo vicioso. Uma vez que, o mercado de trabalho pleiteia inúmeras qualificações para contratação de um funcionário principalmente quanto ao critério de educação, torna-se impossível adquirir tais competências se o Estado não fornece as oportunidades de estudo.

Portanto, a função das cotas não é "tomar" a vaga ou desmerecer a etnia negra como muitos pensam, mas ampliar os direitos por via da equidade para que TODOS tenham as mesmas oportunidades de frequentar as universidades e cursos almejados.

\section{ARGUMENTOS DESFAVORÁVEIS À POLÍTICA DE COTAS RACIAIS}

As cotas raciais, regulamentadas pela Lei 12.711/12, conhecida como Lei de Cotas, surgiram com o objetivo de promover o acesso de candidatos de baixa renda, negros e índios ao ensino superior, por meio de processo seletivo onde o candidato deve indicar a vaga a qual quer pleitear e em qual tipo de cota ele se encaixa, podendo haver uma mistura dos três critérios anteriormente apresentados: cotas para estudantes de baixa renda $\mathrm{E}$ que também se autodeclaram como afrodescentes ou índios.

Referente às cotas e suas três modalidades mais conhecidas, percebe-se em nossa sociedade uma grande aceitação das cotas que contemplam os estudantes de baixa renda, enquanto que, na contramão desta aceitação, temos uma grande aversão relacionada às cotas raciais. Tal aversão possui diversas motivações, destaca-se o argumento de que as cotas raciais ferem o princípio da meritocracia, inserindo um aluno em um plano de ensino a qual ele, por si só, não alcançaria sem ter o acesso às cotas, pois temos a figura de alguém com uma pontuação menor ficando a frente de alguém com uma pontuação maior devido a sua cor, diminuindo assim o nível e a qualidade do ensino acadêmico oferecido. Neste cenário, temos a clara consequência de que as próprias cotas raciais criam barreiras em relação aos negros, subjugando-os como seres incapazes que necessitam de uma forma de acesso diferenciada ao ensino superior, pois sem as cotas, esses indivíduos não iriam acender a tal vaga por conta própria.

Outro argumento que reforça a aversão às cotas raciais diz respeito ao Sistema Educacional. O Estado brasileiro como sendo o responsável pela educação básica pública e suas diretrizes, deveria investir seus esforços em melhorar o sistema educacional como um todo, proporcionando assim um ensino de qualidade e que dará a todos as mesmas chances de ingressar em uma vaga na universidade. 


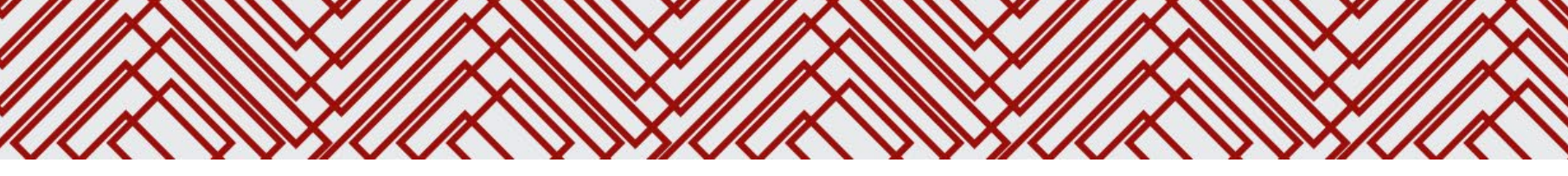

Por último, podemos destacar em relação às cotas raciais que o critério adotado e até mesmo a sua nomenclatura podem ser consideradas errôneas. O critério 'racial' adotado, na verdade, não existe biologicamente, visto que todos os seres humanos pertencem à mesma raça: a raça humana. Considerar que dentro de nossa sociedade existem raças é o mesmo que admitir que dentre essas raças, há uma disparidade intelectual entre elas, se aproximando assim do pensamento de quem, no passado, achava que a raça ariana era superior a todas as outras.

Para complementar, em um país com uma taxa de miscigenação alta como o Brasil, o critério que leva em consideração a cor da pele para confirmar se aquele indivíduo tem direito a cota racial para ingresso em curso superior pode ser falho, deixando aproveitar-se do sistema quem não é afrodescente, ao mesmo tempo que pode recusar este direito a quem de fato o é.

\section{CONCLUSÃO}

A partir do presente trabalho, é possível verificar a longa trajetória percorrida pelas pessoas que fazem parte de grupos sociais discriminados no Brasil, de modo particular, os negros afrodescendentes, que desde o fim da escravidão, vêm lutando por sua liberdade, bem como por um espaço na sociedade e pelo reconhecimento de seus direitos enquanto seres humanos.

No entanto, esse reconhecimento dos direitos é inócuo quando despido de uma política promocional efetiva e capaz de trazer uma redistribuição das oportunidades. A exemplo disso, tem-se que o reconhecimento da necessidade de erradicar a discriminação, por parte do Brasil, se deu em 1968, com ratificação da Convenção para Eliminação de Todas as Formas de Discriminação Racial; nada obstante, não houve uma imediata criação de medidas afirmativas dos direitos previstos na Convenção, de modo que a exclusão e o preconceito se enraizaram na cultura brasileira de tal forma, que são percebidos, até os dias atuais, os estigmas do desamparo e da negligência do Estado em possibilitar a inserção dos negros em todos os âmbitos da vida social.

À vista disso, evidente é a necessidade de conscientização acerca da importância das medidas afirmativas no processo de democratização e diversificação do espaço social, pois só assim as políticas promocionais serão protegidas de argumentos reacionários que eventualmente queiram descaracterizá-las. 
PLANALTO. LEI No 10.558, DE 13 DE NOVEMBRO DE 2002.. Disponível em: http://www.planalto.gov.br/ccivil_03/LEIS/2002/L10558.htm. Acesso em: 2 abr. 2020.

PLANALTO. LEI No 12.288, DE 20 DE JULHO DE 2010.. Disponível em: http://www.planalto.gov.br/ccivil_03/_Ato2007-2010/2010/Lei/L12288.htm. Acesso em: 2 abr. 2020.

PLANALTO. LEI No 12.711, DE 29 DE AGOSTO DE 2012.. Disponível em: http://www.planalto.gov.br/ccivil_03/_ato2011-2014/2012/lei/112711.htm. Acesso em: 2 abr. 2020.

PLANALTO. LEI No 12.990, DE 9 DE JUNHO DE 2014.. Disponível em: http://www.planalto.gov.br/ccivil_03/_ato2011-2014/2014/lei/112990.htm. Acesso em: 2 abr. 2020.

PIOVESAN, Flávia. Ações afirmativas da perspectiva dos direitos humanos. Cadernos de Pesquisa, [s.1.], v. 35, n. 124, p.43-55, abr. 2005. FapUNIFESP (SciELO).http://dx.doi.org/10.1590/s0100-15742005000100004.

SANTOS, B. de S. Reconhecer para libertar: os caminhos do cosmopolitanismo multicultural. Rio de Janeiro: Civilização Brasileira, 2003. Introdução: para ampliar o cânone do reconhecimento, da diferença e da igualdade, p.56.

STF. Notícias STF :: STF - Supremo Tribunal Federal. Disponível em: http://www.stf.jus.br/portal/cms/verNoticiaDetalhe.asp?idConteudo=206042\&caixaBusca=N. Acesso em: 18 mar. 2020.

STF. Notícias STF. Disponível em: http://www.stf.jus.br/portal/cms/verNoticiaDetalhe.asp?idConteudo=278000. Acesso em: 2 abr. 2020.

UOL. Cotas raciais: criação, leis, argumentos pró e contra. Disponível em: https://brasilescola.uol.com.br/educacao/sistema-cotas-racial.htm. Acesso em: 18 mar. 2020.

UOL. Na USP, apenas $\mathbf{2 , 1 \%}$ dos mais de $\mathbf{5 . 0 0 0}$ educadores são pretos ou pardos. Disponível em: https:/www1.folha.uol.com.br/educacao/2019/12/na-usp-apenas-21-dosmais-de-5000-educadores-sao-pretos-ou-pardo.shtml. Acesso em: 2 abr. 2020. 


\title{
CAPÍTULO 3 \\ ANÁLISE SOBRE O ESTATUTO DA PESSOA COM DEFICIÊNCIA SOB A PERSPECTIVA DO STF
}

\author{
Giovanna Baldan \\ Isabela Bartholo Cesar
}

\section{INTRODUÇ̃̃O}

O presente trabalho visa discutir e analisar a decisão do Supremo Tribunal Federal proferida na Ação Direta de Inconstitucionalidade 5.357, ajuizada pela Confederação Nacional dos Estabelecimentos de Ensino - CONFENEN, em face dos Artigos 28, parágrafo 1 e Artigo 30 - caput, do Estatuto da Pessoa com Deficiência.

\section{DOS DIREITOS E GARANTIAS FUNDAMENTAIS - SURGIMENTO E CONTEXTO SÓCIO-HISTÓRICO-CULTURAL}

Os direitos fundamentais, também conhecidos como direitos humanos, direitos individuais ou direitos subjetivos públicos, são direitos assegurados aos indivíduos como uma forma de proteção frente à atuação do Estado, incorporando-se ao texto constitucional a fim de garantir os direitos imprescindíveis à condição do homem e de seu convívio em sociedade. Os direitos humanos decorrem de construções sociais e refletem os fatos históricos relevantes e as necessidades coletivas de um determinado período da História.

Para uma melhor compreensão deste tema, analisemos o surgimento das dimensões dos direitos humanos ao longo da História.

Os direitos humanos de primeira geração surgiram em decorrência da Declaração dos Direitos do Homem e do Cidadão em 1789, o que, posteriormente, deu origem à Revolução Francesa, influenciada pelos ideais iluministas de "liberdade, igualdade, fraternidade". Como se sabe, esse documento tinha como escopo a defesa dos direitos civis e políticos dos cidadãos, além do caráter negativo da atuação do Estado, ou seja, exigia-se a abstenção da esfera estatal em relação à sociedade, tendo em vista o poder absoluto exercido pelos monarcas na época. 


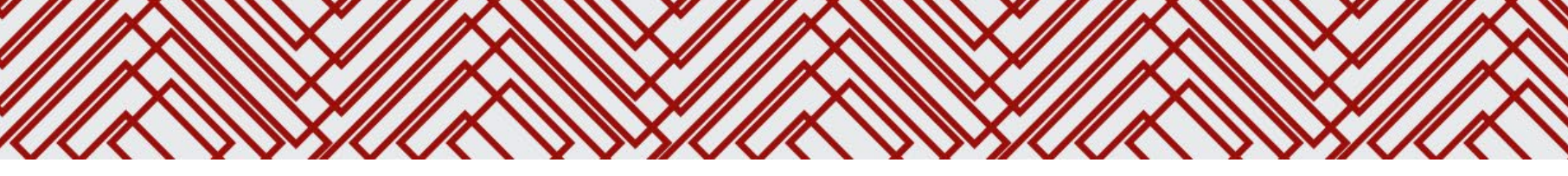

Nesse sentido, a Declaração buscou assegurar os direitos civis, a fim de garantir a liberdade do homem e, os direitos políticos, como uma forma de possibilitar a igualdade na participação política por meio da defesa do sufrágio universal pelos revolucionários.

Em seu Artigo primeiro, a Declaração de Direitos do Homem e do Cidadão, de 1789, estabelece que:

"Os homens nascem e permanecem livres e iguais em direitos. As distinções sociais só podem fundar-se na utilidade comum".

Assim sendo, concluímos que os direitos fundamentais de primeira dimensão estão consubstanciados aos valores de liberdade e abstenção do poder estatal, tendo em vista que a sua incorporação ao ordenamento jurídico francês foi possível em decorrência dos movimentos burgueses, como a Revolução Francesa, que defendia os ideais iluministas de igualdade, liberdade, fraternidade e limitação do poder do Estado; confirmando, portanto, a ideia de que os direitos fundamentais decorrem das necessidades coletivas e construções sociais de um determinado período histórico.

A segunda geração de Direitos Humanos surge em uma sociedade marcada pelo período Pós-Guerra, momento em que a dignidade, a segurança e a vida de muitas pessoas foi tirada. Esta geração relaciona-se ao conceito de igualdade e a oportunidade de todos de exercerem uma vida digna. Por tais razões, se fez necessário a intermediação do Estado para fins de implementação de políticas públicas, como: educação, trabalho, lazer, entre outros.

Essa dimensão de direitos humanos pode ser constatada com o advento da Constituição Mexicana de 1917; Constituição de Weimar em 1919, e, posteriormente, o Tratado de Versalhes em 1919.

Esses textos constitucionais materializaram os direitos sociais, econômicos, culturais; além de acentuarem o Princípio da Igualdade. Ademais, o Estado foi incumbido ao cumprimento e garantia desses direitos. Assim, conclui-se que os direitos humanos de segunda dimensão possuem titularidade coletiva, ou seja, visam a proteção de garantias fundamentais à todos os cidadãos. E, por outro lado, possuem caráter positivo, haja vista a necessidade de interferência estatal como forma de possibilitar a proteção e cumprimento desses direitos.

Por sua vez, os direitos fundamentais de terceira geração surgiram a partir dos anos 1960 e estão intrinsecamente ligados aos valores de fraternidade e igualdade. Nessa esteira, estes direitos buscam garantir o progresso, desenvolvimento e a proteção a grupos sociais 
vulneráveis, como por exemplo, o direito das crianças, idosos, adolescentes, portadores de deficiência entre outros.

Essa dimensão de direitos humanos pode ser observada com a promulgação da Constituição Brasileira de 1988. Como uma forma de se desvincular do longo período de Ditadura Militar vivenciado no Brasil, a referida carta constitucional trouxe ao ordenamento jurídico brasileiro alusões ao constitucionalismo e a democracia, organizando a conjuntura político-jurídica do país em um “'Estado Democrático de Direito”. O Estado Democrático de Direito possui como princípio norteador o respeito e a proteção às liberdades civis, direitos humanos, fundamentais e garantias individuais.

Além disso, essa forma de organização político-jurídica incorporou em seu texto constitucional o princípio da dignidade da pessoa humana como um de seus maiores fundamentos, conforme previsão do Artigo 1, III da CF:

"A República Federativa do Brasil, formada pela união indissolúvel dos Estados e municípios e do Distrito Federal, constitui-se em Estado Democrático de Direito e tem como fundamentos: III - a dignidade da pessoa humana". (grifo nosso)

\section{BREVE TRAJETÓRIA HISTÓRICA DO TRATAMENTO ÀS PESSOAS COM DEFICIÊNCIAS}

A evolução histórica das pessoas com deficiências é um assunto pouco discutido, mas que envolve diversas informações importantes para entender a dificuldade de inserção das mesmas em nossa sociedade.

Na Antiguidade, sobretudo na Grécia antiga, em que a perfeição do corpo era bajulada, as pessoas com deficiências sofriam com o abandono, eliminação e, até mesmo, o sacrifício. Alguns acreditavam que essas limitações eram decorrentes de possessões demoníacas, fazendo com que a convivência com esses indivíduos fosse um ato aterrorizante.

Em Esparta, cidade-estado cuja principal referência era o militarismo, os pais deveriam entregar seus filhos recém-nascidos ao Estado, para que fosse realizada uma avaliação da criança. Entretanto, caso esse recém-nascido apresentasse qualquer tipo de deficiência física, o Estado era encarregado de jogá-la de um abismo, conhecido por "Apothetai".

Nas palavras de Licurgo de Plutarco apud Silva: "pois tinham a opinião de que não era bom nem para a criança nem para a República que ela vivesse, visto que, desde o nascimento, não se mostrava bem constituida para ser forte, sã e rija durante toda a vida'’.(PLUTARCO,1953 apud SILVA, 1987, p. 105) 


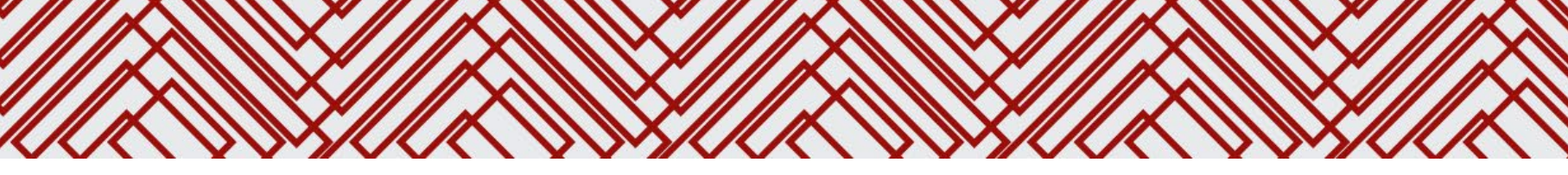

$\mathrm{Na}$ sociedade espartana, práticas como essas eram completamente coerentes, tendo em vista que a maioria dos cidadãos tornar-se-iam guerreiros e, para tanto, deveriam ser fortes e saudáveis.

Por sua vez, na Roma Antiga, era muito comum a utilização das pessoas com deficiências como forma de prostituição e entretenimento das pessoas ricas. Conforme Silva (1987):

cegos, surdos, deficientes mentais, deficientes físicos e outros tipos de pessoas nascidos com má formação eram também, de quando em quando, ligados a casas comerciais, tavernas e bordéis; bem como a atividades dos circos romanos, para serviços simples e às vezes humilhantes (Silva, 1987, p. 130).

Durante a Idade Média, predominavam as concepções místicas, mágicas e misteriosas sobre a população com deficiência. Os impedimentos físicos, intelectuais e afins, eram vistos como um sinal da "ira divina'. Por tais razões, acreditava-se que essas limitações eram decorrentes de um castigo divino ou da possessão do corpo pelo demônio.

Entretanto, com a difusão do Cristianismo, houve uma modificação em relação ao tratamento das pessoas com deficiência. Essa mudança só foi possível graças ao conteúdo da doutrina cristã, que pregava, acima de tudo, o amor ao próximo; o perdão; a humildade e a benevolência.

Assim, nas palavras de Rosanne de Oliveira Maranhão (2005, p.25):

[...] baseava-se na caridade - virtude que tinha como base o sentimento de amor ao próximo, o perdão, a humildade e a benevolência - conteúdo este pregado por Jesus Cristo e que, cada vez mais, conquistava sobremaneira os desfavorecidos. Entre estes estavam aqueles que eram vítimas de doenças crônicas, defeitos físicos e mentais.

\section{A PROTEÇÃO DOS DIREITOS DAS PESSOAS COM DEFICIÊNCIAS NA ESFERA CONSTITUCIONAL}

No século passado, as pessoas com deficiências eram assim caracterizadas em razão de critérios estritamente médicos. Sendo assim, as deficiências constituíam-se por impedimentos físicos, mentais, intelectuais ou sensoriais.

Entretanto, com o advento da Convenção dos Direitos da Pessoa com Deficiência, proclamada pela ONU em 2006 e, posteriormente, com a Lei Federal 13.146 de 2015 ou Estatuto da Pessoa com Deficiência, as necessidades especiais de um indivíduo ultrapassaram as barreiras médicas. Em outras palavras, as pessoas com deficiências são assim caracterizadas não só por seu impedimento físico, mental, intelectual ou sensorial, mas 
também pela relação dessas limitações com os obstáculos presentes na sociedade que obstruem a plena inserção e convívio social dessas pessoas com as demais.

Nesse sentido, segue redação da Lei Federal 13.146 de 2015:

\begin{abstract}
"Art. $2^{\circ}$ Considera-se pessoa com deficiência aquela que tem impedimento de longo prazo de natureza física, mental, intelectual ou sensorial, o qual, em interação com uma ou mais barreiras, pode obstruir sua participação plena e efetiva na sociedade em igualdade de condições com as demais pessoas."
\end{abstract}

Por essas razões, se faz necessário a articulação da sociedade e do Estado para oferecerem mecanismos de acessibilidade como forma de eliminar, ou ao menos, minimizar, as barreiras sociais que impossibilitam o acesso das pessoas com deficiências as mesmas condições de igualdade e oportunidade em relação às demais.

As proteções da dignidade da pessoa humana, assim como a preservação e garantia dos direitos fundamentais e individuais, são consideradas como matéria norteadora de um Estado Democrático de Direito. Conforme aludido nos textos acima, com a promulgação da Constituição Federal de 1988, o Estado Brasileiro, buscou proteger e garantir a efetivação desses direitos.

Nesse contexto, como forma de preservar os grupos mais vulneráveis, a República Federativa do Brasil, assegurou, expressamente, em seu texto constitucional, os direitos e garantias fundamentais referentes às pessoas com deficiência:

\title{
CAPÍTULO I - Dos Direitos e Deveres Individuais e Coletivos
}

Art. $3^{\circ}$. Constituem objetivos fundamentais da República Federativa do Brasil:

(...) IV - promover o bem de todos, sem preconceitos de origem, raça, sexo, cor, idade e quaisquer outras formas de discriminação.

Art. $5^{\circ}$. Todos são iguais perante a lei, sem distinção de qualquer natureza, garantindo-se aos brasileiros e aos estrangeiros residentes no País a inviolabilidade do direito à vida, à liberdade, à igualdade, à segurança e à propriedade, nos termos seguintes:

Art. 208. O dever do estado com a educação será efetivado mediante a garantia de:

(...) III - atendimento educacional especializado aos portadores de deficiência, preferencialmente na rede regular de ensino;

IV - acesso aos níveis mais elevados de ensino, da pesquisa e da criação artística, segundo a capacidade de cada um.

Art. 227. É dever da família, da sociedade e do Estado assegurar à criança e ao adolescente, com absoluta prioridade, o direito à vida, à saúde, à alimentação, à educação, ao lazer, à profíssionalização, à cultura, à dignidade, ao respeito, à liberdade e à convivência familiar e comunitária, além de colocá-los a salvo de toda forma de negligência, discriminação, exploração, violência, crueldade e opressão. 


\section{A INCORPORAÇÃO DA CONVENÇÃO INTERNACIONAL SOBRE OS DIREITOS DA PESSOA COM DEFICIÊNCIA AO ORDENAMENTO JURÍDICO BRASILEIRO}

A Emenda Constitucional n. 45 em seu parágrafo 3, determinou que os tratados internacionais de direitos humanos que fossem aprovados, em cada Casa do Congresso Nacional, em dois turnos, por três quintos dos votos dos respectivos membros, seriam incorporados ao ordenamento jurídico brasileiro com força de Emenda Constitucional.

Até o presente momento, apenas um tratado internacional foi recepcionado pelo Estado brasileiro em conformidade com esse rito: a Convenção Internacional sobre os Direitos da Pessoa com Deficiência, ratificada no governo da presidente Dilma Roussef, pelo Decreto Presidencial no 6.649 (BRASIL, 2009), de 25 de agosto de 2009 e Decreto Legislativo $\mathrm{n}^{\circ} 186$ (BRASIL, 2008), de 9 de julho de 2008.

Posteriormente, como forma de incorporar a Convenção ao sistema infraconstitucional, o Poder Legislativo elaborou a Lei Federal 13.146 de 2015, também conhecida por Estatuto da Pessoa com Deficiência. Logo, tendo em vista que a Convenção Internacional sobre os Direitos da Pessoa com Deficiência é o único tratado internacional recepcionado pelo ordenamento jurídico com força de Emenda Constitucional, é possível constatar tamanha relevância que o referido texto legislativo ocupa no sistema normativo brasileiro.

A Lei 13.146 de 2015busca regulamentar matérias que possam garantir às pessoas com deficiências o exercício de seus direitos e liberdades fundamentais em condições de igualdades com os demais, de modo a promover e assegurar a inclusão social e cidadania. Uma das matérias de maior relevância previstas no Estatuto da Pessoa com Deficiência foi o acesso dos indivíduos portadores de necessidades especiais ao ambiente educacional. Segundo as disposições legais previstas na Lei 13.146 de 2015 (Estatuto da Pessoa com Deficiência), o Estado deve proporcionar e garantir um sistema de educação inclusivo em todos os seus níveis e modalidades de ensino.

Para tanto, como forma de promover as devidas condições de acesso, permanência e participação dos alunos com deficiências, se faz necessário o aprimoramento do ambiente educacional por meio de recursos de acessibilidade que possam assegurar a inclusão plena desses indivíduos nas instituições de ensino, como por exemplo, a disponibilização de docentes que sejam intérpretes de libras ou tradutores, conforme disposto no Artigo 28, inciso XI do Estatuto da Pessoa com Deficiência. 


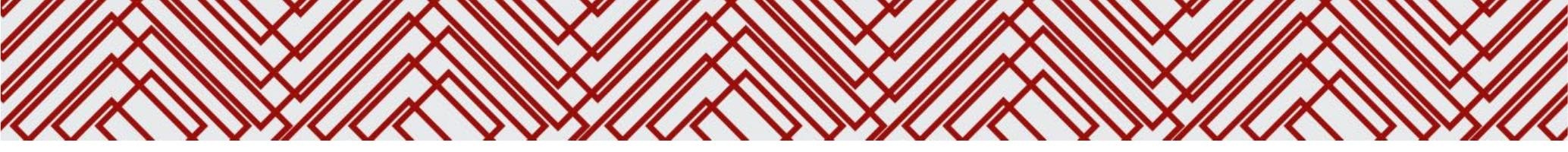

Além disso, os Artigos 28 e 30 da Lei 13.146 de 2015 possuem outras exigências

legais impostas às instituições de ensino:

Art. 28. Incumbe ao poder público assegurar, criar, desenvolver, implementar, incentivar, acompanhar e avaliar:

I - sistema educacional inclusivo em todos os níveis e modalidades, bem como o aprendizado ao longo de toda a vida;

II - aprimoramento dos sistemas educacionais, visando a garantir condições de acesso, permanência, participação e aprendizagem, por meio da oferta de serviços e de recursos de acessibilidade que eliminem as barreiras e promovam a inclusão plena;

III - projeto pedagógico que institucionalize o atendimento educacional especializado, assim como os demais serviços e adaptações razoáveis, para atender às características dos estudantes com deficiência e garantir o seu pleno acesso ao currículo em condições de igualdade, promovendo a conquista e o exercício de sua autonomia;

IV - oferta de educação bilíngue, em Libras como primeira língua e na modalidade escrita da língua portuguesa como segunda língua, em escolas e classes bilíngues e em escolas inclusivas;

$\mathrm{V}$ - adoção de medidas individualizadas e coletivas em ambientes que maximizem o desenvolvimento acadêmico e social dos estudantes com deficiência, favorecendo o acesso, a permanência, a participação e a aprendizagem em instituições de ensino;

VI - pesquisas voltadas para o desenvolvimento de novos métodos e técnicas pedagógicas, de materiais didáticos, de equipamentos e de recursos de tecnologia assistiva;

VII - planejamento de estudo de caso, de elaboração de plano de atendimento educacional especializado, de organização de recursos e serviços de acessibilidade e de disponibilização e usabilidade pedagógica de recursos de tecnologia assistiva;

VIII - participação dos estudantes com deficiência e de suas famílias nas diversas instâncias de atuação da comunidade escolar;

IX - adoção de medidas de apoio que favoreçam o desenvolvimento dos aspectos linguísticos, culturais, vocacionais e profissionais, levando-se em conta o talento, a criatividade, as habilidades e os interesses do estudante com deficiência;

$\mathrm{X}$ - adoção de práticas pedagógicas inclusivas pelos programas de formação inicial e continuada de professores e oferta de formação continuada para o atendimento educacional especializado;

XI - formação e disponibilização de professores para o atendimento educacional especializado, de tradutores e intérpretes da Libras, de guias intérpretes e de profissionais de apoio;

XII - oferta de ensino da Libras, do Sistema Braille e de uso de recursos de tecnologia assistiva, de forma a ampliar habilidades funcionais dos estudantes, promovendo sua autonomia e participação;

XIII - acesso à educação superior e à educação profissional e tecnológica em igualdade de oportunidades e condições com as demais pessoas;

XIV - inclusão em conteúdos curriculares, em cursos de nível superior e de educação profíssional técnica e tecnológica, de temas relacionados à pessoa com deficiência nos respectivos campos de conhecimento;

XV - acesso da pessoa com deficiência, em igualdade de condições, a jogos e a atividades recreativas, esportivas e de lazer, no sistema escolar;

XVI - acessibilidade para todos os estudantes, trabalhadores da educação e demais integrantes da comunidade escolar às edificações, aos ambientes e às atividades concernentes a todas as modalidades, etapas e níveis de ensino;

XVII - oferta de profissionais de apoio escolar;

XVIII - articulação intersetorial na implementação de políticas públicas.

$\S 1^{\circ}$ Às instituições privadas, de qualquer nível e modalidade de ensino, aplica-se obrigatoriamente o disposto nos incisos I, II, III, V, VII, VIII, IX, X, XI, XII, XIII, XIV, XV, XVI, XVII e XVIII do caput deste artigo, sendo vedada a cobrança de valores adicionais de qualquer natureza em suas mensalidades, anuidades e matrículas no cumprimento dessas determinações. 


\begin{abstract}
Art. 30. Nos processos seletivos para ingresso e permanência nos cursos oferecidos pelas instituições de ensino superior e de educação profissional e tecnológica, públicas e privadas, devem ser adotadas as seguintes medidas:

I - atendimento preferencial à pessoa com deficiência nas dependências das Instituições de Ensino Superior (IES) e nos serviços;

II - disponibilização de formulário de inscrição de exames com campos específicos para que o candidato com deficiência informe os recursos de acessibilidade e de tecnologia assistiva necessários para sua participação;

III - disponibilização de provas em formatos acessíveis para atendimento às necessidades específicas do candidato com deficiência;

IV - disponibilização de recursos de acessibilidade e de tecnologia assistiva adequados, previamente solicitados e escolhidos pelo candidato com deficiência;

$\mathrm{V}$ - dilação de tempo, conforme demanda apresentada pelo candidato com deficiência, tanto na realização de exame para seleção quanto nas atividades acadêmicas, mediante prévia solicitação e comprovação da necessidade;

VI - adoção de critérios de avaliação das provas escritas, discursivas ou de redação que considerem a singularidade linguística da pessoa com deficiência, no domínio da modalidade escrita da língua portuguesa;

VII - tradução completa do edital e de suas retificações em Libras.
\end{abstract}

No entanto, as respectivas imposições legislativas previstas nos artigos supracitados, não ficam restritas à responsabilidade estatal.

As disposições legais do Artigo 28, parágrafo 1, se estendem também às instituições de ensino privada. Assim, as instituições particulares, de qualquer nível ou modalidade, deverão, obrigatoriamente, oferecer um ensino inclusivo mediante o aprimoramento de seu ambiente educacional, sem a possibilidade da cobrança de qualquer taxa adicional em mensalidades, anuidades ou matrículas dos alunos com necessidades especiais.

Ao observar as imposições dispostas no Estatuto da Pessoa com Deficiência, sobretudo os Artigos 28 e 30, é certo que essas normas são uma forma de promover a inclusão social dos indivíduos com deficiência para além do ordenamento jurídico brasileiro. Logo, esses artigos devem ser incorporados às situações fáticas, a fim de proporcionar a colocação dos indivíduos com deficiências em condições de igualdade com os demais.

Entretanto, o parágrafo 1 do Artigo 28 e o Artigo 30 - caput da Lei Federal 13.146 de 2015 - Estatuto da Pessoa com Deficiência - foram objeto de discussão na Ação Direta de Inconstitucionalidade 5.357, ajuizada pela CONFENEN (Confederação Escolas Nacionais de Ensino) e distribuída para a relatoria do Ministro Edson Fachin.

\title{
DESDOBRAMENTO DA AÇÃO: DAS ALEGAÇÕES INICIAIS
}

A Confederação Nacional de Ensino ajuizou a respectiva demanda como forma de se desvincular das obrigações educacionais previstas pela Lei Federal 13.146 de 2015 - Estatuto da Pessoa com Deficiência. Essas obrigações, uma vez que foram estendidas ao ensino privado, desvencilhando-se da esfera estatal e da educação pública, geraram grande polêmica 
e foram objeto de discussão da ADI 5.357. Com isso, dado os grandes desafios da aplicação dessa norma, a CONFENEN buscou o reconhecimento da declaração de inconstitucionalidade dos Artigos 28, parágrafo 1, Artigo 30 - caput, da Lei 13.146 de 2015.

Com o Estatuto da Pessoa com Deficiência, os custos extras para a manutenção do atendimento e a inserção de mecanismos de acessibilidade aos alunos com necessidades especiais, não puderam mais ser mais repassados à essas famílias. Por tais razões, essas despesas tiveram que ser diluídas no orçamento das próprias instituições, sendo distribuído à todos os outros alunos.

Em suas alegações iniciais, a CONFENEN afirmou que as imposições legislativas previstas pelos Artigos 28 e 30, violavam os seguintes preceitos constitucionais:

Art. $5^{\circ}$ - caput e incisos XXII e XXIII - (direito de propriedade e sua função social); Art. 170 - incisos II e III - (propriedade privada e III - função social da propriedade);

Art. 205 - "educação é dever do Estado e da família";

Art. 206 - caput e incisos II e III - (liberdade de aprender e de ENSINAR; pluralismo de ideias e de CONCEPÇÕES PEDAGÓGICAS, E COEXISTÊNCIA DE INSTITUIÇÕES PÚBLICAS E PRIVADAS);

Art. 208 - caput e inciso III - (dever do Estado o atendimento a portador de necessidade especial);

Art. 209 - "liberdade de ensino à livre iniciativa"; Art. 227 - dever do Estado e da família, o atendimento já mencionado;

Art. 227, § $1^{\circ}$, inciso II - obrigação do Estado, e

Princípio da Razoabilidade.

Para a Autora, a imposição às escolas particulares de aceitarem todo e qualquer indivíduo com deficiências sem a distinção da natureza, grau ou profundidade dessas necessidades, poderia ocasionar graves riscos econômicos e financeiros às instituições privadas. Isso porque, como forma de assegurar as condições de igualdade de ensino em relação aos demais alunos, se faz necessário o aprimoramento do sistema escolar em consonância com o texto normativo previsto na Lei 13.146 de 2015, o que elevaria substancialmente os custos das prestações de serviços educacionais privados.

Nesse sentido, a Confederação alega que isso poderia acarretar no encerramento das atividades de ensino particulares, tendo em vista a baixa procura das escolas privadas pelos consumidores; além de ocorrer, simultaneamente, a "fuga' em massa dos demais alunos em decorrência do aumento substancial de valores. No entanto, como se sabe, os alunos portadores de deficiência estarão pagando as mesmas mensalidades, assim como aqueles que não possuem necessidades especiais, ou seja, os indivíduos com deficiência também remuneram os ambientes escolares. 
responsabilidade social de inclusão e evolução social desses indivíduos, muito pelo contrário. O ambiente escolar, vai muito além de um espaço destinado à instrução formal dos alunos. Trata-se, pois, de um ambiente em que a criança vai ter contato com a vida fora do âmbito familiar, proporcionando diversas experiências promissoras que serão responsáveis pela formação do caráter e personalidade deste menor. A inclusão mal elaborada dos alunos com deficiências no âmbito educacional pode acarretar em preconceito e discriminação, gerando comportamentos preconceituosos dos demais alunos, como por exemplo, a segregação. Por tais razões, é de suma importância que o ambiente escolar seja adequado para receber alunos com necessidades especiais, visto que o desenvolvimento desses indivíduos estará intrinsecamente ligado à forma de tratamento dos funcionários, alunos e todo o colegiado. Entretanto, quando as escolas não possuem estrutura ou os mecanismos necessários para atender às pessoas com deficiência em condições de igualdade com as demais, a discriminação e a segregação tomam forma, criando mais um obstáculo para a inserção desses indivíduos ao ambiente coletivo.

Para tanto, se faz necessário nivelar as desigualdades nos espaços escolares, adequando as atividades às limitações de cada aluno, assim, somente quando a particularidade de cada pessoa for observada, respeitada e adequada dentro de uma instituição de ensino é que fica possível criar um ambiente de vivências. Nas palavras de Couture: "o procedimento lógico de corrigir desigualdades é o de criar outras desigualdades. ",

\section{ÁCORDÃo}

A ação direta de inconstitucionalidade 5.357 foi julgada improcedente, de modo que os dispositivos ora impugnados pela CONFENEN, foram reconhecidos como pertencentes ao ordenamento jurídico brasileiro.

Para o Ministro Relator Edson Fachin:

Se é certo que se prevê como dever do Estado facilitar às pessoas com deficiência sua plena e igual participação no sistema de ensino e na vida em comunidade, bem como, de outro lado, a necessária disponibilização do ensino primário gratuito e compulsório, é igualmente certo inexistir qualquer limitação da educação das pessoas com deficiência somente a estabelecimentos públicos ou privados que prestem o serviço público educacional.

O Ministro relator do caso, Edson Fachin, ressaltou também a importância da Convenção Internacional Sobre Direitos da Pessoa com Deficiência, visto que este dispositivo foi ratificado pelo Congresso Nacional com força de Emenda Constitucional e é a base do Estatuto da Pessoa com Deficiência. Assim, existe uma norma internacional ratificada pelo Congresso Nacional, com status de emenda constitucional, que originou uma norma interna, 
regulando e aperfeiçoando aquilo que o Brasil já havia ratificado externamente. Isso seria um dos motivos para que o Estatuto seja cumprido de forma adequada, tanto por instituições de ensino público como privado.

O Ministro Luiz Fux, também acompanhou o voto do relator. No início de seus votos, citou sobre a busca de uma sociedade justa, solidária e que respeite a dignidade da pessoa humana, previsto no preâmbulo da Constituição Federal. Para ele, as escolas particulares não devem ser excluídas de suas responsabilidades sociais. E, o que chama atenção em seu voto é o fato de que o Ministro trata até mesmo das crianças com deficiências psíquicas; lembrando que a maioria delas são muito bem cuidadas e tratadas pelos pais antes de serem inseridas em um ambiente com as demais. Nas palavras de Fux: "Se eu pudesse, assentaria como tese não jurídica, mas uma tese sob o ângulo vivencial, que o preconceito é a pior das deficiências."

Por fim, temos os votos da Ministra Cármen Lúcia, a qual citou a história de um garoto que na década de 40 foi recusado por diversas escolas pelo fato de ser uma criança ' 'diferente', No entanto, esse menino contou com o apoio de Helena Antipoff, a qual afirmou que ele não era diferente, mas sim, um gênio. Diante dessa exposição, a Ministra finaliza seus votos afirmando que a real deficiência está no sistema por não acolher o diferente; além disso, o diferente não significa ser melhor ou pior, mas apenas diferente.

\section{CONCLUSÃO}

A Constituição Federal assegura em seu Artigo 206, inciso I, o 'acesso ao ensino em igualdade de condições"'. Com isso, as instituições de ensino privada não podem e não devem se eximir de sua responsabilidade social, tendo em vista que, ao negar aos indivíduos portadores de deficiências mecanismos de acessibilidade que proporcionem condições de igualdade e oportunidades com aqueles que não possuem deficiências, é o que, de fato, fere a Constituição.

Nesse sentido, a Convenção Internacional sobre Pessoa com Deficiência, juntamente com a Lei 13.146 de 2015, garantem a proteção de um grupo social, o qual já é naturalmente isolado e excluído devido à estereótipos injustificados, de que, os mesmos não são capazes ou merecedores da participação da vida em comunidade. Logo, não faz sentido declarar a inconstitucionalidade de um texto normativo que apenas concretiza as diretrizes de uma Convenção Internacional, a qual foi recepcionada pelo ordenamento jurídico brasileiro com força de Emenda Constitucional, tamanha a sua relevância, importância e repercussão em face de uma sociedade ainda intolerante e isolacionista. Uma sociedade verdadeiramente livre, 
justa e solidária, conforme previsto no Artigo 3, inciso I, da Constituição Federal, não se constrói pela exclusão ou tratamento desigual, como requerido pela ADI 5.357 proposta pela CONFENEN. A tentativa de tornar inconstitucional um texto legislativo, que visa proteger e garantir o acesso indiscriminado de pessoas com deficiência aos ambientes escolares, sejam eles públicos ou privados, apenas evidencia o caráter discriminatório e segregacionista presente na referida ação.

Por fim, O Supremo Tribunal Federal, ao reconhecer a constitucionalidade dos Artigos 28, parágrafo 1 e Artigo 30 - caput do Estatuto da Pessoa com Deficiência e julgar improcedente a demanda ajuizada pela CONFENEN, coloca o ordenamento jurídico brasileiro em um novo tempo para a construção de uma sociedade mais humana, justa e fraterna.

\section{REFERÊNCIA}

GALINDO, BRUNO.A INCLUSÃO VEIO PARA FICAR: O DIREITO ANTIDISCRIMINATÓRIO PÓSADI 5357 E A EDUCAÇÃO INCLUSIVA COMO DIREITO DA PESSOA COM DEFICIÊNCIA. Disponível em: $<$ https://periodicos.unipe.br/index.php/direitoedesenvolvimento/article/view/300/282>. Acesso em: 29. Ago. 2020.

AUN USP. Discriminação na educação inclusiva tem origem dentro e fora da sala de aula. Disponível em: http://www.usp.br/aun/antigo/exibir?id=7124\&ed=1240\&f=23. Acesso em: 7 mai. 2020.

CONJUR. ADI 5.357 é um avanço na construção de um direito antidiscriminatório. Disponível em: https://www.conjur.com.br/2016-jun-13/adi-5357-avanco-construcaodireitoantidiscriminatorio. Acesso em: 6 mai. 2020.

FUNDACRED. Aumenta inclusão de alunos com deficiência, mas escolas não têm estrutura para recebê-los. Disponível https://www.fundacred.org.br/site/2018/02/05/aumenta-inclusao-de-alunos-comdeficienciamas-escolas-nao-tem-estrutura-para-recebe-los/. Acesso em: 6 mai. 2020.

MIGALHAS. Acessibilidade nas escolas particulares: quem paga essa conta?. Disponível em: https://www.migalhas.com.br/depeso/268895/acessibilidade-nas-escolasparticularesquem-paga-essa-conta. Acesso em: 6 mai. 2020.

NOTICIAS STF. Escolas particulares devem cumprir obrigações do Estatuto da Pessoa com Deficiência, decide STF. Disponível em: http://www.stf.jus.br/portal/cms/verNoticiaDetalhe.asp?idConteudo=318570. Acesso em: 8 mai. 2020.

NOVA ESCOLA GESTÃO. Apenas $\mathbf{2 6 \%}$ das escolas públicas são acessíveis a pessoas com deficiência. Disponível em: https://gestaoescolar.org.br/conteudo/1851/apenas-26- dasescolas-publicas-sao-acessiveis-aos-portadores-de-deficiencia. Acesso em: 9 mai. 2020. 
PESSOAS COM DEFICIÊNCIA - ONU. A ONU e as pessoas com deficiência. Disponível em: https://nacoesunidas.org/acao/pessoas-com-deficiencia/. Acesso em: 9 mai. 2020.

PRIORIDADE ABSOLUTA. EM DEFESA DE UMA EDUCAÇÃO MAIS INCLUSIVA. Disponível em: https://prioridadeabsoluta.org.br/agenda-227/garantia-erespeito-a-politica-deeducacao-inclusiva-amicus-curiae-na-adi-5357/. Acesso em: 7 mai. 2020.

TALENTO INCLUIR. Discriminar Pessoas com Deficiência é crime. Disponível em: https://talentoincluir.com.br/emprego/ola-mundo/. Acesso em: 7 mai. 2020. 
históricos são questionáveis e duvidáveis, uma vez que toda história possui mais de uma versão, distinguindo-se das demais de acordo com o ponto de vista adotado.

Após certo tempo de estudo, Ellwanger logo adotou a teoria de que os fatos conhecidos popularmente sobre o Holocausto são meros mitos criados pelos judeus como forma de incriminar injustamente os alemães. Segundo o editor, os fatos narrados e disseminados, como as câmaras de gás e o número de mortos, não são fatos concretos, apenas especulações. Além disso, S.E. Castan ressalvava que as verdadeiras vítimas da Segunda Guerra Mundial foram os alemães e não os judeus, o autor defendia que as histórias terríveis de massacre eram mecanismo para enfraquecer economicamente a Alemanha, que segundo ele era uma potência que desestabilizava os EUA e demais Estados europeus.

As manifestações do gaúcho, que já estavam sob análise do poder judiciário, eram seguidas por diversos jovens e antissemitas que viviam no Brasil, mas o Sr. Ellwanger obteve maior visibilidade quando, em 2005 três judeus foram espancados em Porto Alegre.

O crime foi cometido por um grupo de skinheads que já havia sido condenado dois anos antes a realizar serviços à comunidade decorrente da agressão a um grupo punk. No entanto, durante a investigação de 2005, foram encontrados panfletos, livros, cds, cartazes e outros materiais que incitavam o ódio racial. Durante aquele período Ellwanger foi identificado como um dos líderes mais influentes do neonazismo no Brasil, fato que permaneceu algum tempo após a condenação no STF, pois o mesmo permaneceu vendendo suas obras via internet.

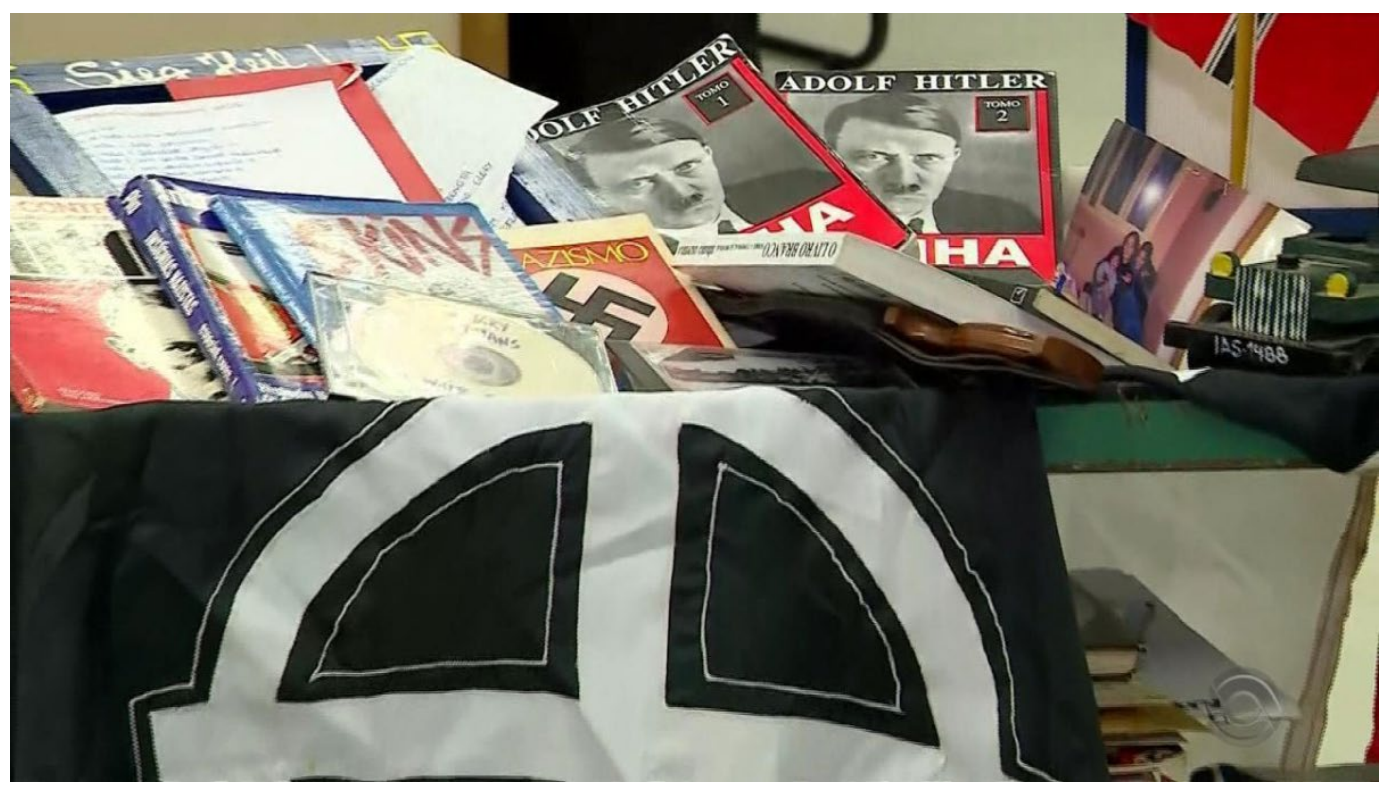

Materiais encontrados no domicílio dos autores do crime de agressão aos judeus em 2005 em Porto Alegre- RS. 


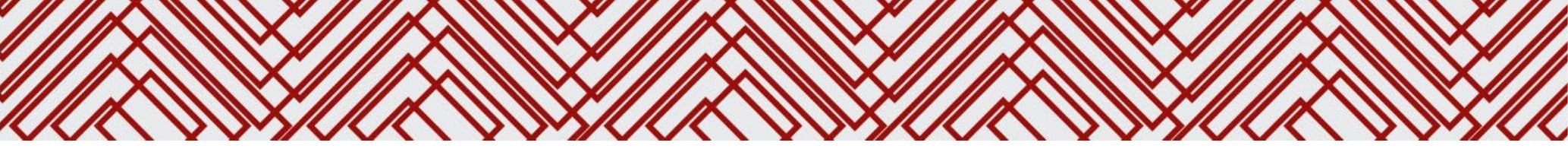

A denúncia do espancamento foi movida pelo Mopar (Movimento popular antirracista), grupo que reunia diversas minorias, dentre elas judeus, negros, juntamente do Movimento pró direitos humanos e justiça.

Vale lembrar que esta denúncia foi somada ao processo que já estava em andamento contra Ellwanger. A ação judicial pautava-se justamente nos argumentos do Mopar para responsabilizar o autor das obras neonazistas sobre os atos crescentes contra judeus e outras minorias no Rio Grande Do Sul.

Após o caso de espancamento o Ellwanger foi condenado em 2006 pelo Tribunal de Justiça de Porto Alegre a 1 ano e 3 meses de reclusão, em regime aberto, substituída pela obrigação de prestar serviços à comunidade e prestação pecuniária pelo crime de indução e incitação de preconceito e discriminação racial decorrente da Feira do Livro de Porto Alegre de 1996, em que o sócio da Editora Revisão colocou em exposição para a venda ao público vários livros editados pela empresa com conteúdo trazendo mensagens racistas, discriminatórias e preconceituosas, incitando e induzindo ao ódio e ao desprezo contra o povo de origem judaica, informou a denúncia oferecida pelo Ministério Público.

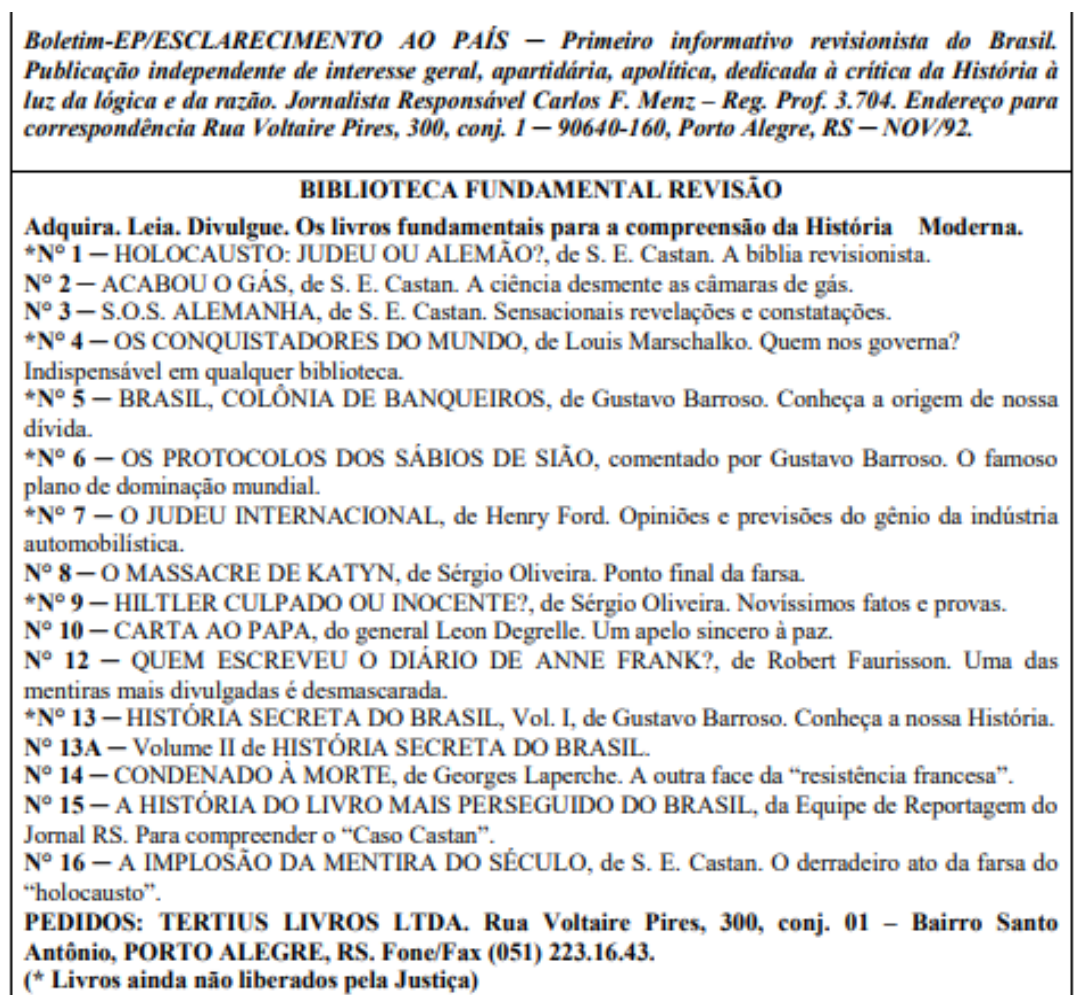

A imagem corresponde a um quadro reproduzido "ipsis litteris" de uma obra da Editora de Ellwanger. Observe atentamente quais são os títulos indicados como leitura essencial.

Desta forma, o acontecimento de 2005 impactou negativamente o andamento do processo de Ellwanger, mas o fato corroborou para o debate e questionamento quanto ao 
crime de racismo, sobre a hipótese se cabe ou não, neste tipo penal, a proteção aos judeus. Ademais, fomentou a discussão quanto a liberdade de expressão, seus possíveis limites e responsabilidade subjetiva dos agentes de acordo com suas obras frente a condutas alheias.

\section{ARGUMENTOS A FAVOR DA CONCESSÃO DO HABEAS CORPUS}

\section{VERIFICAÇÃO DOS POVOS DE ORIGEM JUDAICA COMO UMA RAÇA}

Foi observado, inicialmente, em determinar o significado e o alcance da expressão "racismo", em virtude do caráter imprescritível da prática do delito decretado por força do disposto no artigo $5^{\circ}$, XLII, da Constituição Federal, visto que tal característica não engloba os crimes de discriminação ou preconceito, tipificados por legislação infraconstitucional.

Nesse sentido, é analisado a viabilidade de reconhecer o povo de origem judaica como uma raça e, consequentemente, constatar se houve ou não o crime de racismo por Siegfried Ellwanger para fins de reconhecimento da prescrição do delito.

A prática do crime de racismo no Brasil, no entanto, possui um forte elemento histórico quando se é analisado sob a perspectiva da concepção da Carta Magna de 1988 em razão da existência, por séculos, de uma sociedade escravocrata no país, em que foi utilizada mão-de-obra proveniente de países africanos para o desenvolvimento econômico do Estado.

Todavia, o racismo não será, como advertiu Manoel Gonçalves Ferreira Filho, eliminado de um sopro pela lei, o que certamente se enxerga em inúmeras privações de direito que a população negra é sujeitada a conviver na sociedade atualmente.

Dessa forma, o crime de racismo determinada pela Constituição Federal converge para o significado de preconceito ou de discriminação racial, mais especificamente contra a raça negra.

\section{CONSIDERAÇÕES DE NICOLA ABBAGNANO ACERCA DA CENSURA}

A censura, em suas diversas formas, merece preocupação e o repúdio.

A censura é tema recorrente de debates e entendimentos jurídicos, sendo interessante, portanto, perfilhar impactos históricos, com enfoque no Direito brasileiro, a fim de analisar as possíveis repercussões que a repressão desse direito fundamental possa vir a causar. Primeiramente, cabe ressaltar o modo como a Declaração Universal dos Direitos Humanos trata o tema da liberdade de expressão: este direito inclui a liberdade de, sem interferências, ter opiniões e de procurar receber e transmitir informações e idéias por quaisquer meios (...). 


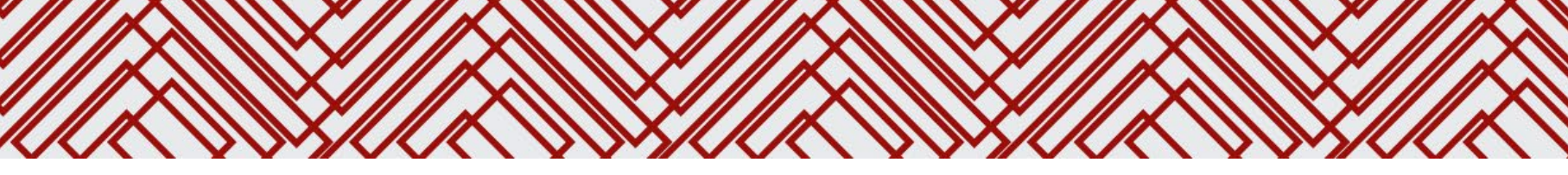

E ainda, como consta no Pacto de São José da Costa Rica: Toda pessoa tem direito à liberdade de pensamento e de expressão. Este direito compreende a liberdade de buscar, receber e difundir informações e idéias de toda indole (...)

Tais documentos demonstram que a liberdade de expressão é garantia não só constitucional, mas também de outros documentos importantes para a legislação interna.

Além disso, historicamente, a censura de documentos e obras jornalísticas se mostra ineficaz para os fins que buscava. O exemplo mais famoso e que se assemelha ao caso em questão, é a criação do "index librorumprohibitorum" na época da inquisição; documento tal que buscava banir obras específicas do rol das que eram apropriadas para os cristãos. Hoje, sabe-se que o critério de escolha das obras buscava o direcionamento do conhecimento para um caminho completamente controlado pelos dogmas cristãos, mostrando uma atitude que, da ótica democrática, parece bem equivocada.

Mais do que isso, pode-se citar o caso da determinação dada por Rui Barbosa, de que, depois da abolição da escravatura, fossem queimados todos os documentos referentes ao período, a fim de que fosse apagada a "mancha histórica". Exemplo que também corrobora para a ideia de que a censura não é meio eficaz para resolver os problemas relacionados a divulgação de períodos históricos controversos.

\section{CONSIDERAÇÕES DE NICOLA ABBAGNANO ACERCA DO TEMA}

Nicola Abbagnano, respeitado filósofo italiano, destacou que a compreensão sobre raças deve ser exclusiva aos grupos humanos qualificados por diferentes características, como a cor da pele, a forma da cabeça e do rosto, a cor dos olhos, entre outros, de modo que, tradicionalmente, existem três grandes raças: a branca, a amarela e a negra.

Logo, não é possível considerar como raças grupos nacionais, geográficos, linguísticos, culturais ou religiosos, como são os judeus.

\section{OBSERVAÇÕES DE HENRY SOBEL E SAMUEL M. STAHL A RESPEITO DO POVO JUDEU}

Ainda, o rabino Henry Sobel, ex-presidente do Rabinato da Congregação Israelita Paulista, acentua a existência de judeus de diferentes espécies, como brancos e negros, designando, portanto, uma condição biológica, e traduzindo, em seu entendimento, que os judeus não constituem uma raça. 


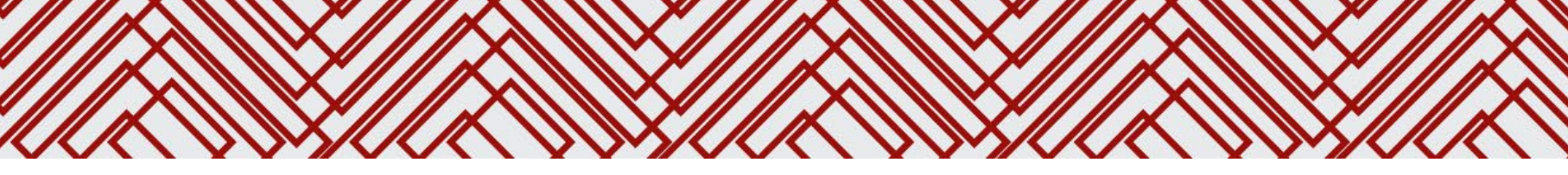

Em outra perspectiva, o rabino Samuel M. Stahl esclareceu, em uma de suas pregações, se os judeus realmente seriam uma raça. Diz ele que, naturalmente, os judeus são, em sua grande maioria, caucasianos, mas isso não os fazem constituir uma única raça.

(...) Todavia, nós judeus somos representados em toda a grande comunidade racial. Não temos somente judeus caucasianos, mas também judeus orientais e judeus negros (...)

A melhor definição de judeus que eu encontrei é esta do Dr. Mordecai M. Kaplan: 'Nós judeus somos um povo com uma desenvolvida civilização religiosa'. Sim, nós somos mais que um grupo religioso. Nós judeus somos uma comunidade com religião no seu núcleo essencial' (...).

\section{A LIBERDADE DE EXPRESSÃO É ELEMENTO NECESSÁRIO PARA O ESTADO DEMOCRÁTICO DE DIREITO}

Os direitos fundamentais são preceitos indispensáveis a estrutura de sustento e eficácia da democracia, e mais do que isso, em especial o direito fundamental da liberdade de expressão realiza um papel determinante para o exercício dos valores democráticos, tais como o direito de discurso, direito de opinião, direito de imprensa, direito à informação e a proibição da censura. É por meio dele que ocorre a participação democrática, e este permite que as opiniões possam ser externadas de forma aberta, sem o receio de contrariar-se a opinião do Estado ou a opinião majoritária, e é com esse exercício que se torna possível construir uma sociedade livre e plural.

A liberdade de expressão é um elemento da democracia, pois estabelece um ambiente sem censura, onde várias opiniões são manifestadas e contrapostas, corroborando para a formação do pensamento da comunidade política. Ao protegermos este direito, defende-se também a liberdade de qualquer pessoa expressar opinião, ainda que absurda ou até mesmo radical, podendo promover inclusive mudanças políticas e sociais desejáveis, e servir como instrumento de controle da atividade governamental. Como é dito no voto do Ministro Marco Aurélio: "Reduzir a liberdade de expressão a um enfoque meramente individual significa podar, de maneira erosiva, a própria democracia".

Por fim, zelando pelo cumprimento dos incisos IV, VIII e XIII do artigo $5^{\circ}$ da Constituição Federal, não se pode dizer que é possível formular regra geral para o exame entre liberdade de expressão e proteção da dignidade humana de forma abstrata, sendo necessária a análise do caso concreto. Dessa forma cabe analisar questões como: se a liberdade de expressão está configurada, se o ato atacado está protegido por essa cláusula constitucional, se de fato a dignidade de determinada pessoa ou grupo está correndo perigo, se essa ameaça é grave o suficiente a ponto de limitar a liberdade de expressão ou se, ao 
contrário, é um mero receio subjetivo ou uma vontade individual de que a opinião exarada não seja divulgada, se o meio empregado de divulgação de opinião representa uma afronta violenta contra essa dignidade, entre outras questões.

\section{O AUTOR NÃO INSTIGOU OU INCITOU A PRÁTICA DO RACISMO POR MEIO DA OBRA}

Existem se encontra no livro qualquer afirmação que insinue a superioridade da raça alemã sobre uma "raça" judaica, ou de que os judeus seriam inferiores se comparados com uma "raça" ariana. A discordância com as ideias expostas não indica uma possível revolução nacional, até porque a maioria dos brasileiros sequer tem o hábito de ler. Visto isso, o Estado deve se manifestar quando a divulgação da idéia ocorra de maneira violenta ou com risco de se disseminar no seio da sociedade. A intervenção estatal à liberdade de expressão deve ser entendida com máxima excepcionalidade, quando há indícios de que houve um grave abuso no exercício.

Ademais, o conteúdo do livro não é transmitido ao leitor independentemente da vontade e, sendo assim, apenas apresenta o pensamento, enquanto cabe ao público escolher o que vai ser lido, e a posição a se tomar ao término da leitura. Tal conteúdo só encontra condições de proliferar-se quando a comunidade política revela um ambiente propício à proliferação do que nele registrado, e não pelo livro isoladamente. Não há inclinações relevantes da sociedade brasileira a aceitar idéias preconceituosas contra o povo judeu, pelo contrário, a imagem da cultura judaica via de regra gozam de amplo apoio e interesse popular.

\section{A COLISÃO ENTRE OS DIREITOS FUNDAMENTAIS REQUER A ANÁLISE DO PRINCÍPIO DA PROPORCIONALIDADE}

\section{Quanto à conformidade ou de adequação dos meios.}

É preciso discutir se a medida é apropriada para concretizar o objetivo visado, considerando o interesse público. No caso analisado, proibir o autor de publicar os pensamentos, apreender e destruir as obras não é meio adequados ao combate à discriminação contra o povo judeu. Isso porque, transmitir a terceiros a sua versão da história não significa que os leitores irão concordar, e, consequentemente discriminar os judeus.

\section{Quanto a ausência de exigibilidade ou necessidade desses meios.}

Deve haver uma reflexão no sentido de buscar outros meios que poderiam igualmente atingir o fim almejado, a um custo ou dano menor aos interesses dos cidadãos em geral. Tal 
meio se restringiria a conceder a ordem, garantindo a liberdade de expressão, já que uma possível restrição não garantirá sequer a conservação da dignidade do povo judeu.

\section{Quanto à proporcionalidade em sentido estrito.}

O intérprete deve refletir se o resultado obtido é proporcional ao meio empregado e à carga coativa interventiva dessa medida, ou seja, ponderar sobre a adequação entre meio e fim, considerando os valores do ordenamento jurídico vigente. Em outras palavras, quanto mais grave a intervenção, mais graves devem ser as razões que a justifiquem.

\section{O PRECONCEITO CONTIDO NO LIVRO NÃO É CONDENÁVEL JURIDICAMENTE, POIS NÃO SE CONFUNDE COM DISCRIMINAÇÃO}

Preconceito indica conceito prévio, opinião formada antecipadamente, sem maior ponderação ou conhecimento dos fatos, ideia preconcebida, e só se torna punível quando é posto em prática, isto é, quando gera a discriminação. Esta sim é juridicamente punível, e significa separar, apartar, segregar, sem que haja fundamento para tanto.

\section{A JURISPRUDÊNCIA COMPARADA LIDA DE MANEIRA ADVERSA COM QUESTÕES RELATIVAS AO PRINCÍPIO DA LIBERDADE DE EXPRESSÃO}

Assim como mencionado, o tema da liberdade de expressão é historicamente presente na construção do direito internacional. Na jurisprudência Alemã, entende-se que a manifestação de pensamento não está necessariamente relacionada a apologia da conduta apropriada, valorizando-se a liberdade acadêmica e incluindo declarações polêmicas no âmbito de proteção dos direitos fundamentais. São exemplos dessas resoluções o caso Luth, o caso livro sobre a guerra, o caso soldados assassinos e o caso do romance pornográfico.

Para a jurisprudência Americana, fonte essencial do sistema utilizado pelos norteamericanos, há precedentes no sentido de que a liberdade de expressão tem o objetivo de promover a "disputa", além de condenar a demasiada restrição a esse direito. Pode-se apreender tais elementos dos casos: TERMINIELLO v. CHICAGO, R.A.V. v. CITY OF St. PAUL, e TEXAS v. JOHNSON.

Por fim, na jurisprudência espanhola, assemelha-se a presente discussão ao julgado do caso da "Publicação contra o povo judeu". Diferente do que é aferido da obra de Ellwanger, na publicação espanhola, foram reconhecidas injúrias de caráter desnecessário, sem qualquer valor informativo ou de formação de opinião, descaracterizando o exercício da liberdade de 
expressão, pois esta deveria respeitar o direito alheio, fundamental para a convivência pacífica, que não ocorria na espécie.

\section{O JULGAMENTO DO HABEAS CORPUS É EXEMPLO DE “JURISPRUDÊNCIA SIMBÓLICA"}

A chamada Jurisprudência simbólica ocorre quando o Estado faz leis destituídas de eficácia para solucionar mazelas nacionais, com grande carga simbólica, visando respaldar os anseios da população. Isso pode ocorrer por razões diversas, sejam elas, confirmar valores sociais; demonstrar a capacidade de ação do Estado ou adiar a solução de conflitos sociais por meio de compromissos dilatórios.

Assim, no caso, o Tribunal, ao relativizar a garantia da liberdade de expressão, condenando o autor, busca perpetuar uma imagem politicamente correta perante a sociedade. Porém, o julgamento não buscava discutir o sofrimento que o povo judeu vivenciou, que constituem fatos inegáveis, que jamais serão esquecidos, mas a possibilidade de expressar um ponto de vista próprio e alheio por meio de livro, ainda que de forma polêmica.

\section{A INCERTEZA DA APLICAÇÃO DO CONCEITO DE IMPRESCRITIBILIDADE}

O direito constitucional brasileiro tem estrutura baseada nos direitos fundamentais, sendo a presente Constituição conhecida como documento do povo brasileiro, tendente a resolver os nossos próprios problemas. Por essa característica do atendimento a necessidades cultural e historicamente brasileiras, que não há nela qualquer menção ao povo judeu quando fora discutido o racismo.

$\mathrm{O}$ instituto da imprescritibilidade de crime entra em choque com as garantias fundamentais, pois eterniza a responsabilidade sobre atos ou manifestações, descartando qualquer possibilidade de evolução, mudança de opiniões e de atitudes, gerando um ambiente de total insegurança jurídica. Este instituto é aplicado em casos como o genocídio (crime perpetrado com a intenção de destruir grupos étnicos, sociais, religiosos ou nacionais), mostrando qual a seriedade de um caso que possa requerer a imprescritibilidade.

No escorço histórico, no Brasil, sempre houve o repúdio à adoção da imprescritibilidade. Em nenhuma das Constituições anteriores há menção a crimes imprescritíveis, e por isso mesmo, a interpretação do inciso XLII do artigo 5 o da Constituição deve ser a mais limitada possível, sob pena de se criar um tipo constitucional penal aberto. 


\section{ATIPICIDADE DA CONDUTA}

$\mathrm{O}$ artigo $5^{\circ}$, inciso XXXIX da Constituição Federal, dispõe que, segundo o princípio da legalidade "não há crime sem lei anterior que o defina, nem pena sem prévia cominação legal". Portanto, entende-se que a conduta praticada pelo agente não configura crime, visto que, a lei que o qualifica como tal não havia sido promulgada.

Em consonância, o princípio da reserva legal, inciso II do art. $5^{\circ}$ da Constituição, traz que "ninguém será obrigado a fazer ou deixar de fazer alguma coisa, senão em virtude de lei". Mais uma vez se nota que não há crime devido a ausência de legislação que tipificasse o ato, e sendo assim, não poderia ser exigida conduta diversa da que praticou o agente.

Ademais, tendo em vista, que nenhum dos autores produziu prova, ainda na instância originária, de que o delito se concretizou após a publicação da Lei Federal no 8.081 de 1990. Sendo este, fato que tinha o dever de provar, porque até a data de vigência da lei, anteriormente citada, o crime não havia sido tipificado.

\section{EXCLUDENTES CONSTITUCIONAIS DA ABUSIVIDADE}

Há três comportamentos que são caracterizados como excludentes constitucionais de abusividade. São eles a crença religiosa, a convicção filosófica e a convicção política.

Vale ressaltar que estes comportamentos também são matéria dos direitos e garantias individuais, como dispõe o inciso VIII do art. $5^{\circ}$ da Carta Magna: "ninguém será privado de direitos por motivo de crença religiosa ou de convicção filosófica ou política, salvo se as invocar para eximir-se de obrigação legal a todos imposta e recusar-se a cumprir prestação alternativa, fixada em lei”.

A partir de tal dispositivo, se torna possível entender que o direito de liberdade de expressão ganha maior proteção quando utilizado em um dos três campos citados. Nesse sentido, a prática realizada por Ellwanger estaria protegida pela liberdade de expressão.

\section{AMBIVALÊNCIA E ACEPÇÕES DO VOCÁBULO "RACISMO"}

É inegável que quando o poder constituinte originário elaborou a norma constitucional, trouxe o termo "racismo" em alusão a realidade do país, afinal a norma deve se relacionar ao histórico existente que, neste caso, o vocábulo é visto como discriminação ou preconceito. Uma discriminação e preconceito que abrange, principalmente, aquele sofrido pela população negra no país. 


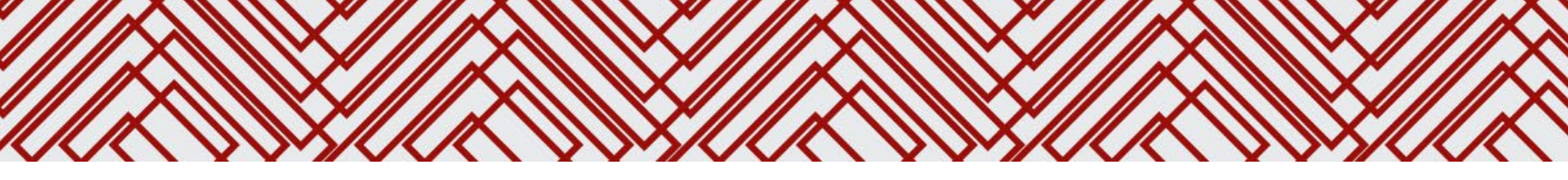

Além disso, é importante expor que o legislador constituinte deixou de explicar a quem se destinaria a proteção do racismo. Ao ler o vocábulo, o intérprete fica inclinado a relacionar "racismo" com "raça", termo que foi citado juntamente a outros como modalidade de preconceito no inciso IV do art. $3^{\circ}$ da Constituição: "promover o bem de todos, sem preconceitos de origem, raça, sexo, cor, idade e quaisquer outras formas de discriminação".

Verifica-se também que o vocábulo "cor" foi destacado no referente inciso, o que leva a deduzir que preconceito de raça e preconceito de cor são figuras diferentes. Ocorre que esse pensamento conduz à negação da história do povo negro no Brasil, as particularidades do processo que levou a promulgação da Constituição Cidadã em 1988 e a linguagem popular que, evidentemente, relaciona "racismo" como sinônimo de preconceito de cor.

\section{ARGUMENTOS CONTRA A CONCESSÃO DO HABEAS CORPUS}

\section{CRIME IMPRESCRITÍVEL}

Por se tratar de conteúdo meramente político-social, o racismo gera discriminação e preconceito segregacionista, sendo necessário levar em conta os fatores e circunstâncias históricas, políticas e sociais. Para que o disposto no artigo $5^{\circ}$, inciso XLII da Constituição Federal seja realmente alcançado, o conceito de racismo deve abranger conceitos etimológicos, etnológicos, sociológicos, antropológicos e biológicos.

Destarte, é necessária uma análise histórica para que se possa concluir se os judeus são uma raça ou não e, assim, reconhecer a imprescritibilidade do crime de discriminação contra os judeus. Se a existência da raça ariana depende da existência da raça judaica/semita, se a raça ariana existe, o seu oposto também existe.

Portanto, a discriminação contra judeus é originada do pensamento nacional-socialista, que acredita na existência de raças distintas, os judeus e os arianos, sendo a raça ariana considerada superior, infringindo os padrões sociais e étnicos estabelecidos pela Constituição Federal. Assim, obras que negam e subvertem fatos históricos incontroversos como o holocausto, equivalem à incitação à discriminação com conteúdo racista, encaixando-se no disposto no artigo $5^{\circ}$, inciso XLII da Constituição Federal.

A Constituição distingue qualquer discriminação atentatória dos direitos e liberdades fundamentais da prática do racismo, determinando a punição de ambas e outorgando à última hipótese a imprescritibilidade. 


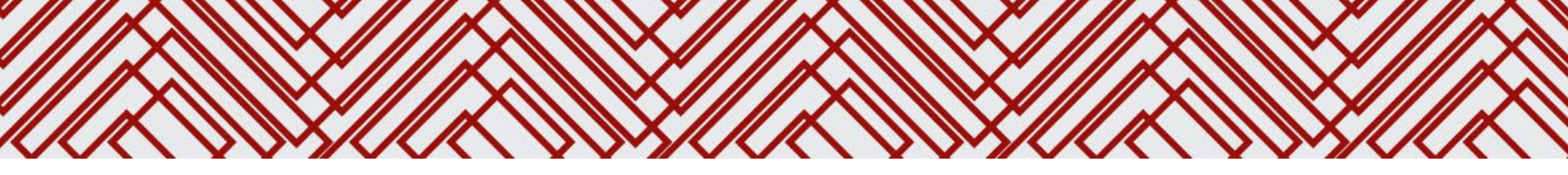

Deste modo, apesar dos judeus serem considerados um povo, não uma raça, o antissemitismo é uma forma de racismo, sendo os atos discriminatórios antissemitas, crimes imprescritíveis na visão da Constituição Federal.

É importante ressalvar que, apesar de a Lei 7.716/89 modificada pela Lei 8.081/90 não contemplar o princípio da imprescritibilidade, a discriminação, o menosprezo e desrespeito contra o povo judeu caracteriza crime inafiançável e imprescritível de racismo, uma vez que a divisão da espécie humana em raças não tem fundamento científico, mas sim, social, não dependendo de fatores biológicos.

Ademais, em decorrência da discriminação contra o povo judeu ter sido considerada uma prática de racismo, esta está sujeita à cláusula de imprescritibilidade, como previsto para uma das hipóteses contidas no artigo 20 da Lei 7.716/89, a de prática de racismo.

\section{LIBERDADE DE EXPRESSÃO X DIREITO À DIGNIDADE}

A liberdade de expressão, prevista na Constituição Federal de 1988, é um direito fundamental do cidadão. Entretanto, como todos os axiomas constitucionais, não é um princípio absoluto, já que seu exercício deve respeitar os limites éticos e jurídicos.

Desta forma, quando há abuso na prática da liberdade de expressão, ou seja, publicações que extrapolam os limites da indagação científica, visando o insulto e estímulo à intolerância, o Estado torna-se legítimo para atuar, expondo o(s) autor(es) do ato às sanções penais ou civis.

No caso concreto, a liberdade de expressão deve ser afastada, haja vista que, ao abordar conteúdo imoral, Ellwanger ultrapassou os limites dispostos na Constituição. Devese, portanto, prevalecer os princípios da dignidade da pessoa humana e da igualdade.

Por um outro lado, tratando-se de manifestação de natureza criminosa, não deve ser protegida pela Constituição Federal e, portanto, não cabe falar de confronto de princípios constitucionais.

DOLO NA AÇÃO

Ellwanger, ao publicar livro de conteúdo anti-semita, realizou julgamentos deliberados e específicos contra os judeus, deixando claro o dolo em sua conduta. Desta forma, configurase o crime de racismo, tendo, portanto, consequências no âmbito criminal. 


\section{OS GRUPOS NEONAZISTAS E ELLWANGER}

A influência de Ellwanger na disseminação de ideias neonazistas/antissemitas/racistas se torna patente diante da análise do caso fático ocorrido no ano de 2005 , na cidade de Porto Alegre. Em maio daquele ano, em meio à comemoração Europeia de 60 anos da vitória dos aliados contra a Alemanha de Adolf Hitler, três estudantes judeus foram espancados por um grupo de skinheads, em cuja residência foram encontrados panfletos, livros, CDs e cartazes que incitam o ódio racial. Em alguns desses materiais havia a autoria de Siegfried Ellwanger Castan, considerado o maior divulgador de ideias racistas no país. Para Ellwanger, membro da Escola Revisionista, as grandes vítimas da Segunda Guerra Mundial foram os alemães, uma vez que, para ele, o nazismo e a morte de milhões de judeus nunca teria, de fato, existido. Ademais, os membros do grupo de skinheads, já inclusive condenados a prestar serviços à comunidade pela agressão de um grupo de punks em 2003, participavam de portais e sites como Orkut para marcar reuniões, discutir e trocar materiais sobre o ódio racial, entre os quais também estão os livros de Ellwanger.

Desta feita, nota-se que, Ellwanger, com seu discurso discriminatório aos judeus, fomenta a ação de pessoas que, como este grupo de skinheads, já possuíam uma mentalidade racista, mas que com o incentivo do autor revisionista, ganham a certeza do poder de ação e acabam machucando pessoas inocentes. Pessoas estas que estão vivendo suas vidas normalmente até que são mal vistas pela cultura em que nasceram, por aquilo que elas são e, até, pela história de seus antepassados. Essas pessoas são vítimas do preconceito racial incentivado por Ellwanger, fazendo com que Direitos Fundamentais sejam violados.

A Constituição de 1988 atenta à dignidade da pessoa humana e seus direitos, constando em seu artigo $5^{\circ}$, inciso XLI que "a lei punirá qualquer discriminação atentatória dos direitos e liberdades fundamentais" e, ainda, o inciso XLII estabelece que "a prática do racismo constitui crime inafiançável e imprescritível, sujeito à pena de reclusão nos termos da lei". Além disso, no item 17 da Resolução 623/98 da Assembléia Geral, nota-se que a interpretação sobre o racismo praticado contra árabes e muçulmanos refere-se igualmente ao anti-semitismo. Desse modo, como o sistema brasileiro adota normas internacionais, como normas de Direitos Humanos como Emendas Constitucionais, fica claro que a discriminação praticada por Ellwanger é prática de racismo e interfere diretamente no plano fático ao influenciar pessoas a violar os direitos fundamentais de outras, devendo assim, ser considerado imprescritível o crime. 


\section{CONDUTA DE ELLWANGER É CRIME FORMAL}

Ellwanger e suas condutas caracterizam delito contra a comunidade judaica, haja vista que fora ele o autor de racismo no âmbito da tipicidade direta e, por ser crime formal, também não é exigido resultado material, apenas a mera conduta do agente.

\section{CONCLUSÃO}

Siegfried, ao influenciar na disseminação de ideias neonazistas e infringir os limites da liberdade de expressão, atuou com dolo, configurando, assim, crime formal e imprescritível. Desta forma, conclui-se que, neste caso concreto, deve ser indeferido o Habeas Corpus impetrado em favor de Siegfried Ellwanger.

\section{DECISÃO DO STF}

Primeiramente, em 1991 foi recebida a denúncia contra o escritor Siegfried Ellwanger na $8^{\text {a }}$ Vara Criminal da Comarca de Porto Alegre, sendo absolvido em primeiro grau. Após, em decisão proferida pelo Tribunal de Justiça do Rio Grande do Sul, foi o réu condenado a dois anos de reclusão com "sursis" em julgamento no ano de 1996. Além disso, o Habeas Corpus damandado em favor de Siegfried Ellwanger, por sua defesa, foi indeferido pela $5^{\mathrm{a}}$ Turma do Superior Tribunal de Justiça. Assim, ingressou em instância superior, inserindo o Habeas Corpus 82.424-2 do Rio Grande do Sul no Supremo Tribunal Federal, ao alegar que a decisão do Superior Tribunal de Justiça deveria ser revista.

Sendo assim, o Ministro Moreira Alves, relator do caso, alega que o crime que o livreiro havia cometido não era racismo e não se enquadra nos moldes do art. $5^{\circ}$, XLII, da $\mathrm{CF} / 88$. Dessa forma, chegou à conclusão de que o racismo dizia respeito à discriminação racial, quanto à raça negra, e que de acordo com diversos estudos os judeus não eram uma raça.

Ademais, Moreira Alves considerou que o crime praticado por Ellwanger não foi de racismo, afastando a imprescritibilidade e assim, entendeu pela extinção de punibilidade do crime cometido, deferindo o HC impetrado.

Além disso, divergindo de Moreira Alves, o Ministro Murício Côrrea e o Ministro Celso de Mello apontam que é impossível esquecer os danos advindos do holocausto e pelo partido nacional socialista, assim como, também é impossível esquecer das conquistas que surgiram após a Segunda Guerra Mundial como a Declaração Universal dos Direitos da Pessoa Humana. Sendo assim, os Ministros partem para a defesa do direito à dignidade e 
integridade de todos, afirmando que existe apenas uma raça, a raça humana, e assim, preservando os direitos essenciais. Por fim, indeferiu o Habeas Corpus de Ellwanger e mantém a condenação penal imposta pelo TJ/RS, sustentada também pelo Superior Tribunal de Justiça.

Dessa forma, o Ministro Gilmar Mendes, também indefere o Habeas Corpus, pois considerou o acórdão do STJ como não exorbitante, e considera também que as obras que foram publicadas pela editora de Ellwanger estimulam a violência contra os judeus, e assim, atingem a dignidade da pessoa humana quanto à comunidade judaica. Nesse mesmo sentido, a Ministra Ellen Gracie definiu o conceito de raça da Enciclopédia Judaica e nessa linha, também negou o HC.

Entretanto, diferentemente do Ministro Gilmar Mendes, o Ministro Marco Aurélio afirma que Ellwanger não cometeu crime de racismo, mas sim de discriminação contra os judeus, o que o ministro considera distinto, pois a interpretação da Constituição Federal para ele é que o racismo previsto é apenas contra negros. Dessa forma, Marco Aurélio, deferiu o Habeas Corpus. Outro ministro que também deferiu o Habeas Corpus, foi o ministro Carlos Ayres Britto, pois seguiu a idéia de que o crime cometido pelo livreiro era atípico.

Por fim, o Supremo Tribunal Federal, por maioria de sete a três, manteve a condenação de Siegfried Ellwanger imposta a ele pelo Tribunal de Justiça do Rio Grande do Sul por crime de racismo. Sendo assim, ao final ocorreu decisão mais justa, em favor de uma sociedade mais igualitária.

Mister ressaltar que, diante do debate referente os aspectos técnico-legais do caso em tela, seja a possibilidade de prescrição ou a tipificação da conduta, a decisão configura notória vitória para a causa dos Direitos Humanos no Brasil.

Há de se considerar, também, que é fato notório que a região sul foi recipiente de intenso fluxo migratório europeu pós segundos guerra mundial, é inclusive conhecido fato histórico que muitos oficiais do regime nazista vieram para a américa latina buscando refúgio, ressaltando a importância da decisão em suprimir outras instâncias de crimes de ódio provenientes desta ideologia tóxica.

Em 2014, foi noticiado pelo território nacional o caso do professor de história Wandercy Antônio Pugliesi, que colecionava artefatos nazistas e até possuía uma piscina adornada de uma suástica em sua residência. Em 1998, a pedido do Ministério Público Federal, o professor teve sua "coleção" apreendida. Ainda, corroborando o afeto de Wandercy 
pela ideologia Nacional Socialista de Hitler, a notoriedade que a notícia trouxe para o professor trouxe à luz ainda mais um fato preocupante: este batizou seu filho de "Adolf".

$\mathrm{O}$ caso do professor, infelizmente, é apenas mais um exemplo da existência e sobrevivência dos ideais genocidas do nazismo em território brasileiro, reforçando a importância da decisão do STF no caso Ellwanger.

\section{REFERÊNCIA}

Resumo: o caso ellwanger. Disponível em: https:/ensaiosenotas.com/2018/05/23/resumo-ocaso-ellwanger/. Acesso em: 20 mar. 2020.

IZIDORO, Taynara. O caso Ellwanger. 2015. Disponível em: https://izidorotaynara.jusbrasil.com.br/artigos/170411083/o-caso-ellwanger. Acesso em: 21 mar. 2020.

BRASIL. Supremo Tribunal Federal. Habeas Corpus n 82.424-2 Rio Grande do Sul. Diário da Justiça. 19 de março de 2004. Relator originário Min. Moreira Alves, Relator do acórdão Min. Maurício Correia. Disponível em $<$ http://redir.stf.jus.br/paginadorpub/paginador.jsp?docTP=AC\&docID=79052>>. Acesso em: 21 de março de 2020.

CASTAN, Siegfried Ellwanger. O caso Ellwanger. Folha de São Paulo. 2004. Disponível em http://www1.folha.uol.com.br/fsp/opiniao/fz0305200410.htm. Acessado em: 21 de março de 2020.

GRANDES Julgamentos do STF: Racismo contra judeus. 2012. Son., color. Disponível em: https://www.youtube.com/watch?v=h8oS6Llj_T4. Acesso em: 21 mar. 2020.

VIOLANTE, João Luís Mousinho dos Santos Monteiro. O caso e seu impacto no Direito Brasileiro. 2010. 130 f. Tese (Doutorado) - Curso de Direito, Pontifícia Universidade Católica de São Paulo, São Paulo, 2010. Disponível em: https://tede2.pucsp.br/bitstream/handle/5345/1/Joao\%20Luis\%20Mousinho\%20dos\%20Santo s\%20Monteiro\%20Violante.pdf. Acesso em: 21 mar. 2020.

SUREMO TRIBUNAL FEDERAL. STF nega Habeas Corpus a editor de livros condenado por racismo contra judeus. Disponível em: http://www.stf.jus.br/portal/cms/verNoticiaDetalhe.asp?idConteudo=61291. Acesso em: 26 mar. 2020.

NSC TOTAL. Saiba quem é o dono da piscina com a suástica no fundo em Pomerode. Disponível em: https://www.nsctotal.com.br/noticias/saiba-quem-e-o-dono-da-piscina-com-asuastica-no-fundo-em-pomerode. Acesso em: 31 mar. 2020.

SUPERINTERESSANTE. Meu professor é nazista. Disponível em: https://super.abril.com.br/historia/meu-professor-e-nazista/. Acesso em: 31 mar. 2020. 


\title{
CAPÍTULO 5
}

\section{NOÇÕES GERAIS DO SISTEMA INTERAMERICANO}

\author{
Giovanna Baldan \\ Pedro Augusto de Castro Simbera \\ Carolina Piccolotto Galib
}

\section{INTRODUÇÃO}

\section{O DIREITO PÓS SEGUNDA-GUERRA}

No início do século XX, predominava na Europa o sistema jurídico-filosófico positivista. Em decorrência deste sistema, as relações jurídicas eram interpretadas em conformidade àquilo que estava previsto na Lei, sendo esta interpretação condicionada ao Princípio da Legalidade. Logo, a aplicação do Direito ficava estritamente limitada a sua perspectiva formal. Em outras palavras, esse sistema não se preocupava com o conteúdo material da norma ou com o contexto social a que devia sua aplicação. No entanto, com o advento da Segunda Guerra Mundial, a teoria jurídica positivista foi responsável por legitimar o genocídio dos judeus pelos nazistas na Alemanha, o Holocausto. Por essas razões, houve a ruptura com o Positivismo Jurídico, assim, esse sistema foi superado por outras teorias que pudessem enxergar o Direito além de um texto legislativo, interpretando as normas em conformidade com seu conteúdo material e o contexto social. Nas palavras do professor Dirley da Cunha Júnior:

Com efeito, até a Segunda Guerra Mundial, a teoria jurídica vivia sob a influência do Estado Legislativo de Direito, onde a Lei e o Princípio da Legalidade eram as únicas fontes de legitimação do Direito, na medida em que uma norma jurídica era válida não por ser justa, mas sim, exclusivamente, por haver sido posta por uma autoridade dotada de competência normativa (2020).(Grifo nosso)

Com o final da Segunda Guerra Mundial e a consequente ruptura com o sistema positivista, houve a constitucionalização do Direito, sendo que, com essa constitucionalização, o Direito passou a privilegiar a tutela do ser humano. Além de aplicar as normas jurídicas de maneira humanizada. Assim, houve a necessidade de instrumentos adequados para garantir a efetividade dessa constitucionalização. Nesta conjuntura, nascem as organizações mundiais, que possuem a finalidade de promover a cooperação entre as nações a fim de proporcionar a defesa da paz e da segurança mundial. Com isso, houve a criação de mecanismos de proteção para fins de garantir as condições necessárias para que cada pessoa 
possa gozar dos seus direitos econômicos, sociais e culturais, assim como dos seus direitos civis e políticos; sendo que, esses direitos passam a adquirir sua proteção no sistema internacional como forma de complementar e suprir as omissões da atuação da Justiça interna de cada Estado.

Nos tópicos a seguir, estudaremos a função do sistema jurídico de proteção internacional dos países membros da OEA: o Sistema Interamericano de Direitos Humanos, o qual funciona como o instrumento de aplicação, efetivação e interpretação dos dispositivos previstos na Convenção Americana de Direitos Humanos. Este sistema é composto por outros dois órgãos: Comissão Interamericana de Direitos Humanos e a Corte Interamericana de Direitos Humanos.

\section{COMISSÃO INTERAMERICANA DE DIREITOS HUMANOS}

A carta da OEA (criada após o surgimento da OEA em 1948) prevê em seu artigo 106 a existência de uma "Comissão Interamericana de Direitos Humanos", (doravante, "Comissão" e "CIDH") com a finalidade de promover o respeito e a defesa dos direitos humanos. Foi também previsto que através de uma Convenção seria estruturada a competência e as normas seguidas pela Comissão.

A Convenção Americana sobre Direitos Humanos, também conhecida como Pacto de San José da Costa Rica (doravante, “Convenção"), foi assinada em 1969 e entrou com vigência em 1978, tinha previsão em seu artigo 33 da existência de uma Comissão e de uma Corte Interamericana de Direitos Humanos. De tal modo que pudessem, através de suas competências, analisar o cumprimento dos compromissos assumidos pelos Estados ao ratificarem a Convenção. (Salienta-se que a Comissão tem previsão tanto na Carta da OEA, quanto na Convenção)

A Comissão Interamericana tem sede em Washington, é composta por 7 membros. Tem a função de formular recomendações aos Estados membros para que adotem medidas que assegurem os direitos humanos.

A Comissão tem uma atividade quase-judicial, verifica a aplicação dos preceitos contidos na Convenção, poderíamos pensar como o Ministério Público verificando a aplicação da lei. Ser quase-judicial quer dizer que a comissão não prolata sentença, de tal sorte, ao reconhecer a infração do Estado, quanto as garantias previstas na Convenção, depende intimamente da boa-fé do Estado em atender a suas recomendações. Em outros termos, as recomendações não são decisões judiciais obrigatórias. 


\section{CORTE INTERAMERICANA DE DIREITOS HUMANOS}

A Corte Interamericana de Direitos Humanos, juntamente com a Comissão Interamericana de Direitos Humanos, compõe o Sistema Interamericano de Direitos Humanos. A corte é uma instituição judicial autônoma, que possui como função aplicar e interpretar os dispositivos da Convenção Americana, tratado internacional de proteção dos direitos humanos, assinado pelos países membros da OEA. Bem como, possui como objetivo a função contenciosa que visa a resolução de casos contenciosos e supervisão de sentenças e a função consultiva que, por sua vez, busca a realização de medidas provisórias.

\section{COMPOSIÇÃO}

A Corte Interamericana de Direitos Humanos é composta por sete juízes, eleitos a título pessoal dentre juristas da mais alta autoridade moral, de reconhecida competência em matéria de direitos humanos e que reúnam as condições requeridas para o exercício das mais elevadas funções judiciais, de acordo com a lei do Estado do qual sejam nacionais, ou do Estado que ou do Estado que os propuser como candidatos.

Não pode haver mais de um juiz da mesma nacionalidade. Além disso, os juízes não podem conhecer de casos de sua nacionalidade. Entretanto, em casos interestatais é possível sim que os Estados nomeiem um juiz ad-hoc da nacionalidade dos Estados envolvidos no caso em questão. Os juízes da Corte são eleitos para um mandato de seis anos, com a possibilidade de apenas uma reeleição.

\section{COMPETÊNCIA CONTENCIOSA}

A competência contenciosa da Corte Americana se dá em função da resolução de casos litigiosos, juntamente com a ferramenta de supervisão das sentenças. Nesse sentido, a Corte vai analisar os processos judiciais internacionais levados a julgamento no âmbito da CIDH. No entanto, para que um caso seja submetido perante a Corte, se faz necessário que tenha sido esgotado todo os procedimentos perante a Comissão. Além disso, apenas os Estados-partes e a Comissão têm o direito de submeter um caso à análise da Corte, sendo que, o Estado demandado tenha reconhecido a competência contenciosa da Corte.

A Corte não pode aceitar petições formuladas por indivíduos ou organizações. As pessoas físicas ou organizações que reconhecerem seu direito violado e que tenham esgotado todos as possibilidades de recursos internos, podem recorrer ao Sistema Interamericano. No entanto, deverão encaminhar suas denúncias, primeiramente, à Comissão. 


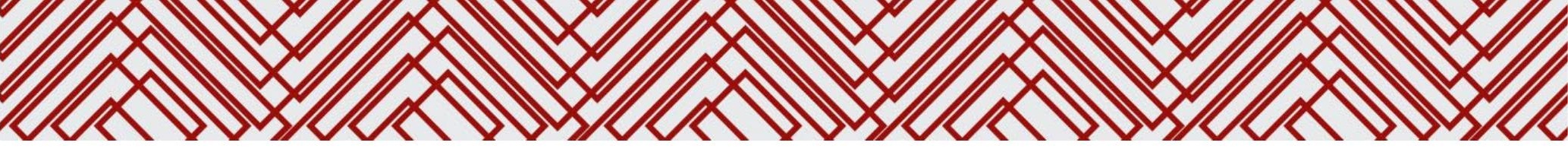

A supervisão do cumprimento das sentenças da Corte possibilita o pedido de informações ao Estado demandado referentes às atividades desenvolvidas para garantir o cumprimento da sentença. Esse mecanismo de supervisão é uma forma de assegurar a efetividade das sentenças da Corte e do Sistema Interamericano de Direitos Humanos.

\section{FUNÇÃO CONSULTIVA}

A função consultiva da Corte refere-se às consultas formuladas pelos Estados membros da OEA a respeito da compatibilidade de normas internas com a Convenção Americana; e a interpretação da Convenção ou de outros tratados de direitos humanos nos Estados americanos.

\section{SENTENÇA}

A sentença da Corte deve ser fundamentada e esse procedimento possui caráter contraditório, terminando com uma sentença judicial motivada, obrigatória, definitiva e inapelável.

\section{ANEXO 1:}

\section{Convenção Americana de Direitos humanos}

\section{$\underline{\operatorname{Artigo} 44}$}

Qualquer pessoa ou grupo de pessoas, ou entidade não-governamental legalmente reconhecida em um ou mais Estados membros da Organização, pode apresentar à Comissão petições que contenham denúncias ou queixas de violação desta Convenção por um Estado Parte.

\section{$\underline{\text { Artigo } 45}$}

1. Todo Estado Parte pode, no momento do depósito do seu instrumento de ratificação desta Convenção ou de adesão a ela, ou em qualquer momento posterior, declarar que reconhece a competência da Comissão para receber e examinar as comunicações em que um Estado Parte alegue haver outro Estado Parte incorrido em violações dos direitos humanos estabelecidos nesta Convenção.

2. As comunicações feitas em virtude deste artigo só podem ser admitidas e examinadas se forem apresentadas por um Estado Parte que haja feito uma declaração pela qual reconheça a referida competência da Comissão. A Comissão não admitirá nenhuma comunicação contra um Estado Parte que não haja feito tal declaração.

3. As declarações sobre reconhecimento de competência podem ser feitas para que esta vigore por tempo indefinido, por período determinado ou para casos específicos.

4. As declarações serão depositadas na Secretaria-Geral da Organização dos Estados Americanos, a qual encaminhará cópia das mesmas aos Estados membros da referida Organização.

\section{$\underline{\text { Artigo } 46}$}


1. Para que uma petição ou comunicação apresentada de acordo com os artigos 44 ou 45 seja admitida pela Comissão, será necessário:

a. que hajam sido interpostos e esgotados os recursos da jurisdição interna, de acordo com os princípios de direito internacional geralmente reconhecidos;

b. que seja apresentada dentro do prazo de seis meses, a partir da data em que o presumido prejudicado em seus direitos tenha sido notificado da decisão definitiva;

c. que a matéria da petição ou comunicação não esteja pendente de outro processo de solução internacional; e

d. que, no caso do artigo 44, a petição contenha o nome, a nacionalidade, a profissão, o domicílio e a assinatura da pessoa ou pessoas ou do representante legal da entidade que submeter a petição.

2. As disposições das alíneas a e $\underline{b}$ do inciso 1 deste artigo não se aplicarão quando:

a. não existir, na legislação interna do Estado de que se tratar, o devido processo legal para a proteção do direito ou direitos que se alegue tenham sido violados;

b. não se houver permitido ao presumido prejudicado em seus direitos o acesso aos recursos da jurisdição interna, ou houver sido ele impedido de esgotá-los; e

c. houver demora injustificada na decisão sobre os mencionados recursos.

\section{$\underline{\text { Artigo } 47}$}

A Comissão declarará inadmissível toda petição ou comunicação apresentada de acordo com os artigos 44 ou 45 quando:

a. não preencher algum dos requisitos estabelecidos no artigo 46;

b. não expuser fatos que caracterizem violação dos direitos garantidos por esta Convenção;

c. pela exposição do próprio peticionário ou do Estado, for manifestamente infundada a petição ou comunicação ou for evidente sua total improcedência; ou

d. for substancialmente reprodução de petição ou comunicação anterior, já examinada pela Comissão ou por outro organismo internacional.

\section{CONCLUSÃO}

A possibilidade de ajuizar uma demanda perante o Sistema Internacional, sobretudo na Comissão Interamericana de Direitos Humanos, se faz possível mediante o preenchimento de três requisitos de admissibilidade: o Estado acusado deverá ter violado um dos direitos previstos na Convenção; a queixa não pode ser objeto de discussão em outro procedimento internacional e, por fim, o esgotamento dos recursos jurisdicionais internos do Estado em que ocorreu a violação. Observa-se, portanto, que a busca pelo Sistema Internacional para fins de 
proteção de um direito essencial que tenha sido violado, só será possível caso a vítima esgote todos os meios jurisdicionais existentes em seu país. Assim, diante das informações supracitadas, concluímos que a busca pelo Sistema Internacional como forma de alcançar a justiça, se faz presente em situações nas quais o país em que ocorreu a violação de um direito essencial, seja omisso o bastante de modo que todos os meios jurisdicionais previstos tenham sido acionados e, ainda assim, não tenham protegido um direito da vítima.

Isso fica mais claro ao analisarmos o caso "'Maria da Penha":

Maria da Penha Fernandes foi vítima de violência doméstica cometida por seu exmarido. O réu tentou matá-la em duas ocasiões distintas: na primeira vez, com um tiro pelas costas; e, depois, tentou eletrocutá-la na banheira. Como resultado das agressões sofridas, Maria da Penha ficou paraplégica. Por sua vez, o réu, embora tenha sido condenado duas vezes pelos tribunais locais em decorrência da tentativa de duplo homicídio contra a sua exesposa, conseguiu permanecer em liberdade durante 15 anos.

Por essas razões, frente à omissão e morosidade da Justiça Brasileira, Maria da Penha recorreu ao Sistema Internacional a fim de garantir os seus direitos e alcançar a justiça pretendida, apresentando o seu caso à Comissão Interamericana de Direitos Humanos.

A seguir, abordaremos outros casos que, assim como Maria da Penha, sofreram com a omissão e morosidade do Estado brasileiro, devendo recorrer ao Sistema Internacional de Direitos Humanos como forma de proteger a dignidade da pessoa humana e alcançar a justiça pretendida.

\section{REFERÊNCIA}

BRASIL. Carta da Organização dos Estados Americanos. Decreto no 30.544, de 14 de fevereiro de 1952. Diário Oficial da República Federativa do Brasil, Poder Executivo, Brasília, DF, 19 fev. 1952. Disponível em <http://www2.camara.leg.br/legin/fed/ decret/19501959/decreto-30544-14-fevereiro-1952-340000-publicacaooriginal-1-pe.html>. Acesso em: 26ago. 2020.

BRASIL. Convenção Americana sobre Direitos Humanos. Decreto $\mathrm{n}^{\circ}$ 678, de 06 de novembro de 1992. Diário Oficial da República Federativa do Brasil, Poder Executivo, Brasília, DF, 09 nov. 1992. Disponível em <http://www.planalto.gov.br/ccivil_03/decreto/ D0678.htm>. Acesso em: 26ago. 2020.

BASSETTO, Marcelo Eduardo Rossitto. KONNO, Alyne Yumi. O caso do Povo Indígena Xucuru perante a comissão interamericana de direitos humanos. R. Defensoria Públ. União. Brasília, DF. n.12 p. 27-50. jan/dez. 2019.

MARCIEL, Débora Alves. FERREIRA, Marrielle Maia e KOERNER, Andrei. Os estados unidos e os mecanismos regionais de proteção dos direitos humanos. Lua nova, São Paulo, pág.271-295, 2013. 
AMBITO JURIDICO. A trajetória jurídica internacional até formação da lei brasileira no caso

Maria da Penha.

Disponível em:

https://www.brasiljuridico.com.br/artigos/neoconstitucionalismo-e-o-novo-paradigma-doestado-constitucional-de-direito--um-suporte-axiologico-para-a-efetividade-dos-direitosfundamentais-sociais.-por-dirley-da-cunhajunior.\#: : :text=Com\%20efeito\%2C\%20at $\% C 3 \%$ A9\%20a\%20Segunda,sim $\% 2 \mathrm{C} \% 20$ exclusiv amente $\% 2 \mathrm{C} \%$. Acesso em: 26 ago. 2020.

Procuradoria Federal dos Direitos do Cidadão. SISTEMA INTERAMERICANO DE PROTEÇÃO DOS DIREITOS HUMANOS. Disponível em: http://midia.pgr.mpf.gov.br/pfdc/hotsites/sistema_protecao_direitos_humanos/interamericano. htm. Acesso em: 26 ago. 2020. 


\section{CAPÍTULO 6 \\ LEI MARIA DA PENHA: UM PANORAMA DA CORTE INTERNACIONAL ÀS MUDANÇAS ATUAIS}

$\underline{\text { Beatriz Amorim Borelli Muniz }}$ Murilo Mendes Latorre Soares

\section{INTRODUÇÃO}

A humanidade, de fato, evoluiu muito com o passar do tempo, porém, é possível observar um grande atraso em relação a proteção dos direitos das mulheres. A sociedade patriarcal e machista sempre inferiorizou a mulher, que por muito tempo, teve seus direitos e garantias impedidos, podendo-se concluir que o direito não acompanha o tempo dos avanços sociais. Os fundamentos da alienação da mulher têm como ponto de partida o sistema de exploração, sendo este derivado do colonialismo. O mecanismo da alienação da mulher é idêntico ao mecanismo da alienação do trabalhador na sociedade capitalista, ou seja, a sociedade cria e impõe a ideologia e a cultura que defenderão seus valores, assegurando sua existência e seus interesses, inferiorizando a figura feminina e transformando a mulher em uma força produtora sem direitos.

Tornou-se habitual a divulgação de casos de violência doméstica no país, sendo que o Brasil é a quinta nação com maior taxa de feminicídio do mundo. Segundo os dados do Fórum Brasileiro de Segurança Pública, em 2017, 4.936 mulheres foram assassinadas, sendo registrados em torno de 13 assassinatos por dia. Destes feminicídios, o estudo apontou que $28,5 \%$ ocorreram dentro da residência, sendo os autores dos crimes, em sua grande maioria, os esposos das vítimas. No estado de São Paulo, desde o início da pandemia do novo Coronavírus, os casos de violência doméstica, registrados, em comparação ao mesmo período de tempo do ano passado, aumentaram 44,9\% e conforme o Fórum, a quantidade de feminicídio também subiu de 13 para 19 casos (46,2\%) no mesmo período.

No ano de 2006, foi implementada no ordenamento jurídico brasileiro a Lei 11.340, popularmente conhecida como "Lei Maria da Penha", cuja maior finalidade é proporcionar ferramentas para coibir, prevenir e erradicar a violência doméstica e familiar contra a mulher, garantindo sua integridade física, moral, sexual, patrimonial e psíquica em conformidade com a Lei Majoritária ( $\operatorname{art} .226, \S 8^{\circ}$ ) e os tratados internacionais ratificados pelo Estado brasileiro. 


\section{CONTEXTO HISTÓRICO}

Antes de aprofundar no tema a ser discutido, faz-se necessário compreender os caminhos que foram traçados até o surgimento da Lei em questão.

Maria da Penha Maia Fernandes, brasileira, nordestina e farmacêutica bioquímica foi vítima de agressões por parte de seu, então, marido, Marco Antonio Viveros, colombiano. Casados desde 1976, o agressor passou a se mostrar intolerante com sua esposa e filhas e apresentar comportamentos explosivos dentro de casa quando ganhou a cidadania brasileira e se estabilizou profissionalmente, formando, assim, o ciclo de violência: aumento a tensão, ato de violência, arrependimento e comportamento carinhoso. Em 1983, Maria da Penha sofreu a primeira tentativa de homicídio, quando seu marido disparou contra a mesma um tiro de espingarda enquanto dormia. E se não bastasse, o mesmo tentou eletrocutá-la, enquanto tomava banho, após duas semanas que havia retornado do hospital com paralisia nos membros inferiores, resultado da primeira tentativa de homicídio.

Então, foi a partir deste acontecimento que Maria da Penha, representando milhares de mulheres, iniciou sua jornada em busca de justiça e de direitos. Marco Antonio Viveros foi condenado pela primeira vez no Tribunal do Júri da Comarca de Fortaleza no estado do Ceará. A condenação foi anulada, porém, o acusado foi condenado novamente, mas valendose dos meios legais cabíveis contra a segunda decisão condenatória, razão pela qual a decisão não chegou a transitar em julgado e o condenado, por consequência, não foi preso. A sensação de impunidade a falta de suporte legislativo acrescidas da morosidade do sistema judiciário brasileiro, incentivou Maria da Penha a buscar o Sistema Interamericano de Proteção dos Direitos Humanos.

Contando com o suporte do Centro Para a Justiça e o Direito Internacional (CEJIL) e do Comitê Latino Americano e de Defesa dos Direitos da Mulher (CLADEM), Maria da Penha deu início à busca pelos seus direitos, agora, internacionalmente.

Em 20 de agosto de 1998, o caso chegou ao conhecimento da Comissão Interamericana de Direitos Humanos, se tornando caso 12.051 sendo a primeira vez que foi admitida uma petição de crime de violência doméstica. Sendo notificado e acionado para apresentar o contraditório, o Brasil permaneceu ausente, motivo pelo qual, aplicou-se o artigo 38 do Regulamento da Comissão que versa:

Artigo 38. Presunção

Presumir-se-ão verdadeiros os fatos relatados na petição, cujas partes pertinentes hajam sido transmitidas ao Estado de que se trate, se este, no prazo máximo fixado 
pela Comissão de conformidade com o artigo 37 do presente Regulamento, não proporcionar a informação respectiva, desde que, de outros elementos de convicção, não resulte conclusão diversa.

O silêncio brasileiro com relação ao caso deixou o entendimento tácito de que uma solução amistosa- como prevê o regulamento- não era uma opção. No dia $1^{\circ}$ de novembro de 2000 o Brasil recebeu um relatório da Corte que continha, também, algumas recomendações que o país deveria seguir, mais uma vez o país permaneceu inerte e alheio a tudo.

Findo o trâmite na Comissão, o caso foi levado à Corte Interamericana, ocasião em que o Brasil foi julgado e condenado como violador dos direitos humanos, após isso, o país prosseguiu com o julgamento e reiterando a decisão condenatória. $\mathrm{O}$ condenado deu início à pena privativa de liberdade, em regime inicial fechado, em 28 de outubro de 2002. Só em 7 de julho de 2008, Maria da Penha recebeu a indenização do governo do Ceará, também recomendado pela Comissão, no valor de $\mathrm{R} \$$ 60.000,00 (sessenta mil reais).

Outra recomendação, agora feita pela Organização dos Estados Americanos, ponderou que o Brasil visando à criação de políticas públicas inibitórias às violências sofridas por mulheres no âmbito doméstico. Em decorrência disso, deu-se o surgimento de Projetos de Lei que posteriormente originaram a Lei n. 11.340, de 7 de agosto de 2006 - Lei Maria da Penha.

\section{DISCURSSÃO}

A Lei Maria da Penha, como ficou conhecida, inovou e deu início a uma série de mudanças no ordenamento jurídico brasileiro, graças a ela, o ato de violência era classificado como uma infração penal de menor potencial ofensivo em consonância com a Lei 9099/95, agora vê-se como uma violação a direitos humanos reiterada pelo artigo $6^{\circ}$ da lei, lê-se:

A violência doméstica e familiar contra a mulher constitui uma das formas de violação dos direitos humanos.

Assunto contínuo, também determinou que a agressão contra a mulher não se limita à agressão física, e arrolou outros comportamentos desrespeitosos e agressivos que vitimam mulheres, por exemplo: agressão sexual, psicológica, patrimonial e moral.

$\operatorname{Art} 7^{\circ}$

São formas de violência doméstica e familiar contra a mulher, entre outras:

I - a violência física, entendida como qualquer conduta que ofenda sua integridade ou saúde corporal; II - a violência psicológica, entendida como qualquer conduta que lhe cause dano emocional e diminuição da auto-estima ou que lhe prejudique e perturbe o pleno desenvolvimento ou que vise degradar ou controlar suas ações, comportamentos, crenças e decisões, mediante ameaça, constrangimento, humilhação, manipulação, isolamento, vigilância constante, perseguição contumaz, insulto, chantagem, ridicularização, exploração e limitação do direito de ir e vir ou qualquer outro meio que lhe cause prejuízo à saúde psicológica e à autodeterminação; III - a violência sexual, entendida como qualquer conduta que a constranja a presenciar, a manter ou a participar de relação sexual não desejada, 
mediante intimidação, ameaça, coação ou uso da força; que a induza a comercializar ou a utilizar, de qualquer modo, a sua sexualidade, que a impeça de usar qualquer método contraceptivo ou que a force ao matrimônio, à gravidez, ao aborto ou à prostituição, mediante coação, chantagem, suborno ou manipulação; ou que limite ou anule o exercício de seus direitos sexuais e reprodutivos; IV - a violência patrimonial, entendida como qualquer conduta que configure retenção, subtração, destruição parcial ou total de seus objetos, instrumentos de trabalho, documentos pessoais, bens, valores e direitos ou recursos econômicos, incluindo os destinados a satisfazer suas necessidades; V - a violência moral, entendida como qualquer conduta que configure calúnia, difamação ou injúria"

O dispositivo legal também passa a criar uma medida não apenas repressiva mas também preventiva no que tange à violência contra a mulher. É criada uma "força-tarefa" entre o Poder Judiciário, o Ministério Público e a Defensoria Pública, direito este que se desdobra na garantia de que a mulher que estiver em situação de violência doméstica e familiar terá acesso aos serviços de Defensoria Pública ou de Assistência Judiciária Gratuita, nos termos da lei. Dessa forma, ao ser verificada a ocorrência de violência doméstica e familiar contra a mulher, o juiz poderá aplicar ao agressor, medidas protetivas de urgência, são algumas delas:

\begin{abstract}
Art. 22.
Constatada a prática de violência doméstica e familiar contra a mulher, nos termos desta Lei, o juiz poderá aplicar, de imediato, ao agressor, em conjunto ou separadamente, as seguintes medidas protetivas de urgência, entre outras:

I - suspensão da posse ou restrição do porte de armas, com comunicação ao órgão competente, nos termos da; II - afastamento do lar, domicílio ou local de convivência com a ofendida; III - proibição de determinadas condutas, entre as quais: a) aproximação da ofendida, de seus familiares e das testemunhas, fixando o limite mínimo de distância entre estes e o agressor; b) contato com a ofendida, seus familiares e testemunhas por qualquer meio de comunicação; c) freqüentação de determinados lugares a fim de preservar a integridade física e psicológica da ofendida; IV - restrição ou suspensão de visitas aos dependentes menores, ouvida a equipe de atendimento multidisciplinar ou serviço similar; V - prestação de alimentos provisionais ou provisórios.VI - comparecimento do agressor a programas de recuperação e reeducação; e VII - acompanhamento psicossocial do agressor, por meio de atendimento individual e/ou em grupo de apoio.
\end{abstract}

Sob o prisma processual, a Lei inovou ao retirar dos Juizados Especiais a competência para julgar os crimes de violência doméstica contra a mulher, vetando qualquer forma de conciliação e transação penal bem como a suspensão condicional do processo ou aplicação da composição civil dos danos, visando à proteção da vítima. Criou-se, também, a possibilidade do juiz decretar prisão preventiva quando houver riscos à integridade física ou psicológica da mulher. Prelecionou que fossem criados Juizados de Violência Doméstica e Familiar contra a Mulher acompanhados de órgãos da Justiça Ordinária com competência cível e criminal para a fase processual e para a execução das causas decorrentes da prática de violência doméstica e familiar contra a mulher. Caso não haja Vara especializada, as Varas criminais irão suprir essa lacuna e acumularão a competência, tanto cível quanto criminal, para tomar conhecimento e 
julgar as causas que culminaram em violência doméstica e familiar contra a mulher, nessa situação será garantido o direito de preferência para o processo e julgamento dessas causas. Quando vítima de qualquer tipo de agressão, a mulher deve dirigir-se a uma à Delegacia Especializada no Atendimento à Mulher (DEAM), que são unidades especializadas da Polícia Civil, as quais realizam ações de prevenção, proteção e investigação dos crimes de violência doméstica e sexual.

Dentre as inovações, a Lei, ainda, proíbe as penas de cesta básica ou outras de prestação pecuniária, como também substituição de pena que implique o pagamento isolado de multa. Altera o Código de Processo Penal, possibilitando que o juiz decrete a prisão preventiva quando houver riscos à integridade psicológica ou física da vítima, bem como altera a Lei de Execuções Penais permitindo que o magistrado determine o comparecimento obrigatório do agressor a programas de reeducação e recuperação.

Para complementar à lei, a rede de atendimento às mulheres, ao longo dos anos, se ampliou cada vez mais, prezando melhor atender todas as mulheres de todas as regiões do país. Atualmente, existem 220 Centros Especializados de Atendimento à Mulher; 92 Juizados/ Varas especializadas de Violência Doméstica, 501 Delegacias Especializadas no Atendimento à mulher e Núcleos, 59 Núcleos Especializados da Defensoria Pública, e 72 Casas de Abrigo. Tais meios são de extrema importância, pois os mesmos abraçam as vítimas, buscando darlhes suporte, proteção e eficácia na busca por justiça.

Datando uma mudança mais recente, o Supremo Tribunal de Justiça decidiu que violência contra mulher, prevista na Lei Maria da Penha, é crime de ação pública incondicionada, ou seja, não depende de prévia manifestação de qualquer pessoa para ser iniciada, a manifestação da ofendida se torna irrelevante o direito de ação, no caso, cabe ao Estado.

O dispositivo legal também prevê que existam estudos e pesquisas sob a ótica de gênero, raça e etnia da violência doméstica e familiar contra a mulher. O Brasil é o $5^{\circ}$ país no mundo, em um ranking de oitenta e três, em que há mais mortes de mulheres no ano de 2015, segundo o Mapa da Violência, organizado pela Faculdade Latino-Americana de Ciências Sociais (Flacso). Em um período compreendido entre dez anos (2003-2013) houve um aumento de 825 casos de mulheres mortas em condições violentas gerando uma média de 13 feminicídios por dia, culminando em um aumento de $21 \%$ na década. A questão racial foi 
levada em conta e mostra que às mulheres negras é atribuído o pior índice já que no tocante a homicídios, nesse mesmo período houve um aumento de 54,2\%.

\section{CONCLUSÃO}

Pelo breve texto redigido, pode-se observar as principais inovações advindas desta lei o que a torna extremamente necessária e importante para as mulheres a para toda população brasileira. Desde de que passou a vigorar, a norma conquistou apreço e respeito internacional, pois segundo o Fundo de Desenvolvimento das Nações Unidas (Unifem), a Lei Maria da Penha é uma das três leis mais avançadas do mundo, entre as 90 nações que possuem legislação sobre a problemática.

É inegável o marco histórico e a inovação no ordenamento jurídico que adveio com a Lei Maria da Penha que passou a reconhecer a mulher como um sujeito de direitos que precisa de uma ampla proteção estatal corroborada pela discriminação histórica sofrida, não só no Brasil, mas em todo o mundo. Em busca dessa igualdade e de ampliar os meios para se chegar o mais próximo de uma equidade, a legislação brasileira se readequou em face ao problema, como tratamos no tópico anterior.

Em que pese os avanços promovidos pela Lei, muito ainda deve ser feito, principalmente no que diz respeito ao incentivo à vítima da violência para que ela denuncie e eventualmente, ajude durantes investigações. Sabe-se a violência contra a mulher não tem início no momento da agressão e que não se encerra ali, políticas públicas que assegurem a mulher que sua integridade física e psicológica será preservada durante o processo são de sumária importância.

Não há dúvidas de que a tutela que o Estado conferiu às mulheres vítimas dessa violência goza de prestígio e relevância, todavia ainda existem diversas situações de violência que, mesmo sendo apresentadas ao Poder Judiciário, não resultam na condenação do agressor, fato esse que precisa ser, urgentemente, corrigido pelo Estado Brasileiro.

Por fim, reconhecemos que o dispositivo é um marco na história da luta das mulheres contra a violência doméstica. Ser contra esta lei é ser contra os direitos humanos e os violar.

\section{REFERÊNCIA}

BANDEIRA, Lourdes Maria; ALMEIDA, Tânia Mara Campos de. Vinte anos da Convenção de Belém do Pará e a Lei Maria da Penha. 2015. Disponível em: https://www.scielo.br/scielo.php?pid=S0104-

026X2015000200501\&script=sci_arttext\&tlng=pt. Acesso em: 01 ago. 2020 
BARSTED, Leila Linhares. Lei Maria da Penha: uma experiência bem-sucedida de advocacy feminista. 2011. Disponível em: http://themis.org.br/wpcontent/uploads/2015/04/LMP-comentada-perspectiva-juridico-feminista.pdf. Acesso em: 10 ago. 2020.

BEZERRA, Juliana. Lei Maria da Penha. 2019. Disponível em: https://www.todamateria.com.br/lei-maria-dapenha/\#: :text=dependente $\% 20 \mathrm{do} \% 20$ agressor.-

,Hist $\%$ C3\%B3ria,morte $\% 2 \mathrm{C} \% 20 \mathrm{ele} \% 20 \mathrm{a} \% 20$ deixou\%20parapl\%C3\%A9gica.. Acesso em: 29 jul. 2020.

BOND, Letycia. SP: violência contra mulher aumenta 44,9\% durante pandemia: mulheres enfrentam dificuldade para prestar queixa, alerta fbsp. Mulheres enfrentam dificuldade para prestar queixa, alerta FBSP. 2020. Disponível em: https://agenciabrasil.ebc.com.br/direitos-humanos/noticia/2020-04/sp-violencia-contramulher-aumenta-449-durante-pandemia. Acesso em: 29 jul. 2020.

BRASIL. Lei $\mathbf{n}^{0}$ 11.340, 7 de agosto de 2006, LEX: Emenda Constitucional, Poder Executivo. Acesso em: 01 ago. 2020

CALAZANS, Myllena; CORTES, Iáris. O processo de criação, aprovação e implementação da Lei Maria da Penha. 2011. Disponível em: http://themis.org.br/wpcontent/uploads/2015/04/LMP-comentada-perspectiva-juridico-feminista.pdf. Acesso em: 10 ago. 2020.

CORREA, Alzira Josiane; CARNEIRO, Simone Rezende. O Sistema Interamericano de Proteção dos Direitos Humanos e o Caso Maria da Penha. 2010. Disponível em: http://www.portalcatalao.com/painel_clientes/cesuc/painel/arquivos/upload/temp/533990d250 0602997b4cf27ace6189eb.pdf. Acesso em: 01 ago. 2020.

Instituto de Pesquisa Econômica Aplicada. Atlas da Violência. 2019. Elaborada. Disponível em: https://forumseguranca.org.br/wp-content/uploads/2019/06/Atlas-da-Violencia2019_05jun_vers\%C3\%A3o-coletiva.pdf. Acesso em: 14 ago. 2019.

LIBÓRIO, Bárbara. A violência contra a mulher no Brasil em cinco gráficos. 2019. Disponível em: https://epoca.globo.com/a-violencia-contra-mulher-no-brasil-em-cincograficos-23506457. Acesso em: 09 ago. 2020.

MINAS GERAIS. Tribunal de Justiça do Estado de Minas Gerais. Quais as principais inovações da Lei Maria da Penha? Disponível em: https://www.tjmg.jus.br/portaltjmg/perguntas-frequentes/quais-as-principais-inovacoes-da-lei-maria-da-

penha.htm\#.XzmnsOhKjIV. Acesso em: 05 ago. 2020.

MINISTRA DESTACA IMPORTÂNCIA DA LEI MARIA DA PENHA. São Paulo: Cidadania, 11 mar. 2013. Disponível em: https://spbancarios.com.br/03/2013/ministradestaca-importancia-da-lei-maria-da-penha. Acesso em: 05 ago. 2020.

PIOVESAN, Flavia; PIMENTEL, Silvia. A Lei Maria da Penha na perspectiva da responsabilidade internacional do Brasil. 2014. Disponível em: https://assetscompromissoeatitude-ipg.sfo2.digitaloceanspaces.com/2014/02/1_6_responsabilidadeinternacional.pdf. Acesso em: 02 ago. 2020. 
Quem é Maria da Penha. Disponível em: https://www.institutomariadapenha.org.br/quem-emaria-da-penha.html. Acesso em: 02 ago. 2020.

Regulamento da Comissão Interamericana de Direitos Humanos 2009. Disponível em: https://www.oas.org/pt/cidh/mandato/Basicos/RegulamentoCIDH2013.pdf. Acesso em: 02 ago. 2020.

SUDRÉ, Lu; COCOLO, Ana Cristina. A prática da violência, especialmente no ambiente doméstico, deixa dolorosas cicatrizes emocionais e pode levar à morte. Disponível em: https://www.unifesp.br/reitoria/dci/publicacoes/entreteses/item/2589-brasil-e-o-5-pais-quemais-mata-mulheres. Acesso em: 10 ago. 2020

VENTURA, Deisy; CETRA, Raísa Ortiz. O Brasil e o Sistema Interamericano de Direitos Humanos: De Maria da Penha à Belo Monte. 2012. Disponível em: https://saudeglobaldotorg1.files.wordpress.com/2014/02/ventura-cetra-o-brasil-e-o-sidh-201221.pdf. Acesso em: 01 ago. 2020.

VICENTIM, Aline. A trajetória jurídica internacional até a formação da lei brasileira no caso Maria da Penha. 2011. Disponível em: https://www.revistas.una.ac.cr/index.php/derechoshumanos/article/view/3743/3593. Acesso em: 29 jul. 2020. 


\title{
CAPÍTULO 7
}

\section{ANÁLISE DA CONDENAÇÃO DO BRASIL PERANTE A CORTE INTERAMERICANA DE DIREITOS HUMANOS NO CASO GOMES LUND E OUTROS}

\author{
Pedro Augusto De Castro Simbera \\ Carla Letícia Di Tullio Martins \\ Gabriella Teixeira Campos \\ Gabriel Freire Approbato \\ Isabela Arruda Monteiro \\ $\underline{\text { Yngrid Magrin }}$
}

\section{INTRODUÇÃO}

O presente trabalho visa refletir acerca da condenação do Brasil perante a Corte Interamericana de Direitos Humanos, em especial trata-se do caso Gomes Lund e outros, este caso recebe esse nome em homenagem a um dos guerrilheiros desaparecidos na Guerrilha do Araguaia, Guilherme Gomes Lund, que participou de uma luta armada contra a ditadura militar e está desaparecido desde 25 de dezembro de 1973.

O surgimento do movimento conhecido como Guerrilha do Araguaia se dá devido à uma resposta PCdoB (Partido comunista do Brasil) contra o terrorismo cometido pelo Estado durante a ditatura militar. Segundo Kappes (2017, p.20) o PCdoB precisava de uma resposta energética contra os ditames do regime militar, que fosse capaz de libertar o brasil. E dessa forma que inspirados na Revolução Cubana e na Chinesa o PCdoB depois de um árduo estudo de terreno, área, topografia e indicadores socioeconômicos selecionaram um local onde possuía a mínima possibilidade de efetivação de uma batalha de guerrilha, uma vez que a batalha seria longa e o apoio popular deveria ser conquistado, já que a ajuda do estado fosse inexistente (KAPPES, 2017). O local selecionado foi a região da Araguaia que fica na divisa dos estados de Goiás, Maranhão e Pará, próximo às cidades de São Geraldo do Araguaia, Marabá no Pará e de Xambioá, no norte de Goiás (região onde atualmente é o norte do estado de Tocantins, também denominada como Bico do Papagaio).

O movimento era formado por no mínimo 80 guerrilheiros. A maioria dos combatentes consistia em ex-estudantes universitários, membros do partido comunista e trabalhadores liberais que foram mortos durante combate nas selvas da Amazônia e que mesmo assim, depois do combate, cinquenta desses guerrilheiros ainda são considerados 
como desaparecidos. A preparação dos guerrilheiros aconteceu em 1964 com a organização de um pequeno grupo liderado pelo antigo diretor do PCdoB, Armando Gimenez e Osvaldo Orlando da Costa, em uma casa em São Vicente na Baixada Santista.

Entre 1967 e 1971 os guerrilheiros transformaram-se em habitantes locais, abrindo comércios, realizando pequenos trabalhos, abrindo bares, se misturando com a população local, a fim de recrutar mais combatentes. Por fim, em 1970 o grupo já constava com 60 militantes.

Não era uma guerrilha grande, possuíam poucos armamentos e um número muito limitado de combatentes, porém o PCdoB acreditava que em um ou dois anos já poderiam começar a se movimentar, realizando pequenas revoluções rurais locais e uma fuga de prisões e uma desistência a ser realizada em São Paulo e outra em Fortaleza para que o movimento evitasse tomar conhecimento dos militares, porém a realidade foi outra.

Em 1971 dois guerrilheiros desistiram da campanha e foram capturados pelo exército brasileiro, fazendo com que liberassem informações sobre a guerrilha em 1972. Além disso, de São Paulo veio a informação, de que uma das guerrilheiras estava saindo da região do Araguaia para São Paulo. Depois de muita pressão sobre os familiares estes liberaram informação sobre a existência da guerrilha (KAPPES, 2017).

Os Oficiais do Exército Brasileiro ao juntar as informações organizaram sua primeira operação, chamada Operação Bico de Papagaio, que se iniciou em 1972 e perdurou até 1975, com a existência de vários desaparecidos, sendo um desses o objeto desse trabalho que é Gomes Lund.

Em 26 de março de 2009 teve início o caso Gomes Lund, quando a Comissão Interamericana de Direitos Humanos submeteu à Corte uma demanda contra a República Federativa do Brasil que se originou em 07 de agosto de 1995, em nome das pessoas desaparecidas no contexto da Guerrilha do Araguaia e de seus familiares. Em 2001 a Corte expediu o relatório de admissibilidade, e em 31 de outubro de 2008, aprovou o Relatório de Mérito 91/08 nos termos do artigo 50 da Convenção.

A demanda se refere a atribuir responsabilidade do Estado pela detenção arbitrária, tortura e desaparecimento de 70 pessoas entre 1972 e 1975 com o objetivo de erradicar a chamada Guerrilha do Araguaia no período da Ditadura militar no Brasil. A Comissão também submeteu o caso a Corte para também responsabilizar o Estado pela falta de investigações realizada sobre esses desaparecimentos, uma vez que medidas administrativas e 
legislativas restringiram a possibilidade de investigação dos fatos no momento em que estes aconteceram.

O Estado, em 31 de outubro de 2009, apresentou sua defesa alegando ao Tribunal que reconhecesse a incompetência devido a ratione temporis, isto é, o fato ocorreu muito no passado sendo desnecessário julgá-lo por razão do tempo entre a ação proposta e dos fatos narrados. E o desinteresse processual das partes. O que de fato mostra como o Estado sempre tenta afastar sua responsabilidade pelas severas violações aos direitos humanos no Brasil.

\section{O PROCESSO PERANTE O SISTEMA INTERAMERICANO}

\section{ALEGAÇÕES PERANTE A COMISSÃO INTERAMERICANA E O TRAMITE DO PROCESSO}

Em março de 1979 o General João Batista de Figueiredo assumiu a Presidência da República e em agosto do mesmo ano foi sancionada a lei 6.683 , mais conhecida como "Lei de Anistia", que extinguiu a responsabilidade penal de todos que tivessem cometidos crimes políticos ou conexos a estes durante o período de 2 de setembro de 1961 a 15 de agosto de 1979.

A Comissão ressaltou que a "Lei de Anistia" foi e ainda é um obstáculo, que impede que agentes estatais envolvidos em práticas de repressão e violação aos direitos humanos durante o período militar sejam punidos. Ademais, a aplicação de leis de anistia que colaboram para perpetuar violações de direitos fundamentais é contrária à Convenção Americana de Direitos Humanos e à Jurisprudência da Corte, que já declarou que, crimes contra humanidade, como de desaparecimento forçado, são inanistiáveis e imprescritíveis. Desse modo, continuar se valendo da lei 6.683/79 para não reconhecer, reparar e punir os responsáveis por violações dos direitos humanos ocorridas no período militar, é manter a impunidade diante dos ataques a dignidade humana daqueles que foram torturados e executados, além de restringir o direito de acesso à justiça e à verdade dos familiares dos desaparecidos.

\section{Infração ao direito à vida, direito à integridade pessoal e direito à liberdade pessoal}

Em seu julgamento de mérito a Comissão declarou que o Estado violou, com base nos artigos 4, 5 e 7, em relação com o artigo 1.1 da Convenção Americana, os direitos à vida, à integridade pessoal e à liberdade dos desaparecidos. 


\section{Direito ao reconhecimento da personalidade jurídica}

$\mathrm{O}$ artigo $3^{\circ}$ da Convenção Americana declara que todas as pessoas têm direito a personalidade jurídica. O reconhecimento da personalidade jurídica possui algumas dimensões, sendo elas: exercer e gozar de direitos; assumir obrigações; capacidade de agir.

A violação da personalidade jurídica e o desaparecimento forçado se relacionam pelo fato de que o desaparecimento forçado consiste na retirada do indivíduo da proteção dada por lei e a violação da personalidade jurídica pela ocultação de um delito, em tentativa de não haver sanção legal.

Assim, ficou constatado pela Comissão em seu relatório, que o Estado violou, em relação aos desaparecidos na Guerrilha do Araguaia o direito de reconhecimento da personalidade jurídica.

\section{REPRESENTANTES DO GOMES LUND}

Neste ponto os representantes fazem um contraste entre as alegações do Estado e as da Comissão, com a finalidade de formar suas concepções e contestar as alegações do Estado.

\section{Incompetência temporal do Tribunal}

O Estado alegou que a Corte Interamericana não teria competência para julgamento da demanda em questão, por se tratar de fato que ocorreu antes do reconhecimento da competência contenciosa do Tribunal pelo Estado. Entretanto, quando assinado e ratificado a Convenção, o Estado reconheceu a jurisprudência da Corte que coloca a possibilidade de conhecimento das violações continuada ou permanentes mesmo que se iniciem antes do reconhecimento da competência, fato este que fez com que a Corte ratificasse a competência contenciosa por se tratar da natureza continuada do desaparecimento forçado ou que são posteriores a esse reconhecimento. Além disso, a impunidade decorreu por conta da falta de investigação, julgamento e punição dos responsáveis por tais atos, tornando-se, portanto, uma violação continuada por não proteger o direito à verdade e à informação.

\section{Falta de interesse processual}

Neste aspecto, o Estado contesta que as medidas tomadas por ele para a reparação da violação e do dano já teriam sido reconhecidas pela Comissão. No entanto, a Comissão entender ser necessário adotar outras medidas. Dentre elas a promulgação da Lei 9.140/95 que reconhece por parte do Estado a responsabilidade por mortes e desaparecimentos que ocorreram durante o período militar, além do pagamento de indenizações para 59 famílias de 
supostas vítimas. Bem como publicações e realização de atos para resgate da memória e da verdade dos fatos ocorridos. A entrega de documentos para facilitação na busca de restos mortais.

Dessa forma, o Estado entende que tais adoções somadas as que ainda estão em implementação atendem as exigências colocadas pela Corte. Porém, a Comissão coloca em questão que essas medidas ainda não foram totalmente cumpridas, além do Estado ter apresentado seu relatório parcial acerca das recomendações dadas pela Comissão com dois dias de atraso. Dentre as medidas que foram sugeridas por essa, como a asseguração de que a Lei de Anistia não fosse mais um empecilho para punir os responsáveis pelas violações, a determinação por jurisdição interna deste fato, e a publicação com sistematização dos documentos de operações militares.

Por fim, a Corte decidiu por reconhecer as ações tomadas pelo Estado para a reparação da violação, entretanto, não as acolhendo por não terem efeito no interesse da Corte para julgar a demanda em questão.

\section{Falta de esgotamento dos recursos internos}

Ademais, com relação aos recursos internos, o Estado coloca o caráter subsidiário de uma instância internacional em não revisar ou reformar sentença interna e sim apurar se está de acordo com as normas internacionais. Assim, as vítimas precisam esgotar todos os recursos internos disponíveis para que recorra ao Sistema Interamericano.

Enumerou-se alguns recursos os quais afirma que não foram devidamente esgotados antes do peticionamento à Comissão. Sendo esses: a) a Arguição de Descumprimento de Preceito Fundamental $n^{\circ} 153$, b) a Ação Ordinária $n^{\circ} 82.00 .024682-5$, por meio desta que se solicitou a determinação do paradeiro dos desaparecidos, c) ação civil pública n²001.39.01.000810-5, interposta pelo Ministério Público Federal para a clareza dos documentos que haviam em relação às ações militares, d) a ação privada interposta para persecução penal, além das, e) iniciativas do Estado referente às indenizações.

Diante disso, a Comissão deixa em evidência a não produção de efeitos esperados, não produzindo assim medida eficaz para esclarecer os fatos denunciados. Em contraposto da Corte afirma que deixa o Estado livre para comprovação da ocorrência ou não dos recursos internos, mas que no caso em questão o único recurso observado pela Corte que ainda não teria tido o esgotamento seria em relação à Ação Ordinária, não obstante, mesmo esta após 19 
anos do início da ação ainda não havia decisão definitiva no âmbito interno, destacando a morosidade do Estado em solucionar o problema.

\section{Regra da quarta instância e falta de esgotamento a respeito da arguição de descumprimento de preceito fundamental}

Sobre o tema deliberado, sustenta o Estado a oportunidade de abordar o assunto no próprio ordenamento jurídico, assim, o Supremo Tribunal Federal se posicione a respeito sobre questões jurídicas do governo militar.

Questiona a competência da Corte sobre a impossibilidade de análise de questões de mérito em decorrência do não esgotamento dos recursos internos. E sobretudo questiona que o Sistema Interamericano não poderia examinar erros, de fatos e de direitos, dos tribunais nacionais que atuaram dentro das suas competências.

\section{ALEGAÇÕES DO ESTADO}

\section{Direito ao reconhecimento da personalidade jurídica, à vida, à integridade e à liberdade}

O Estado reconhece a sua responsabilidade perante ao acontecimento da Guerrilha do Araguaia, todavia, ainda sustenta que as diversas medidas adotadas, como a Lei dos Mortos Desaparecidos Políticos e a publicação do relatório "Direito à Memória e à Verdade", reforçando que cumpriu com o reforço de honrar os mortos e as vítimas. Opôs-se com a aplicação da "doutrina crimes contra a humanidade".

\section{Direito às garantias judiciais e à proteção judicial}

O Estado explica qual a objetividade da Lei de Anistia, assim em suas palavras, a lei "se insere em um amplo e paulatino processo de abertura política e de redemocratização do país" (CIDH, p. 49), pois isso, ela vem como um pacificador de águas quando se percebe que questões que envolvem processo de transição, ocorre uma procura de alternativas para alcançar a reconciliação.

Sobre as questões levantadas pela Comissão sobre a suposta obrigação de não aplicar as instituições de prescrição e de irretroatividade da lei penal, o Brasil salientou que "o costume internacional não pode ser fonte criadora do direito penal, posto que não oferece segurança jurídica, como sim o faz uma lei em sentido estrito” (CIDH, p. 49).

Com a busca de ser assegurar e garantir os direitos humanos, o Estado pede que a Convenção Interamericana busque uma harmonização com os princípios de garantia da não repetição com o princípio de legalidade que estão em colisão. De modo que as medidas já 
adotadas pelo Estado são suficientes, pois nova decisão que faça com que sejam aplicados mais uma vez para a proteção de crimes que violem os direitos humanos estaria contrário ao princípio de legalidade.

Direito à liberdade de pensamento e de expressão, às garantias judiciais e à proteção judicial

Reforça que houve diversas regularização sobre a sistematização e publicação de informações sobre os mortos e desaparecidos políticos. Além de disponibilizar para consulta os arquivos sobre o assunto, além da adoção de medidas como o projeto "Memórias Reveladas", e uma Comissão Especial para reconstruir os episódios de mortes e desaparecidos durante o regime militar.

\section{Direito à integridade pessoal em relação à obrigação de respeitar os direitos}

A Comissão alegou que o Estado violou o direito à integridade pessoal (art. $5^{\circ} \mathrm{da}$ Convenção Americana) juntamente com o prejuízo aos familiares em relação às supostas vítimas desaparecidas, e em resposta, o Estado "fez muito para sanar o sofrimento dos familiares das vítimas e para revelar os fatos históricos do período anterior” (CIDH, p. 86), reafirmando, também, que efetuou pagamento de indenização aos familiares e para localizar os restos mortais das vítimas como também garantiu o direito à memória e a verdade.

\section{DECISÕES DA CORTE INTERAMERICANA}

\section{Teor da decisão}

Consubstanciando os fatos apresentados, a Corte considera adequado reiterar o fundamento jurídico que sustenta uma perspectiva integral sobre o desaparecimento forçado de pessoas, que viola de maneira permanente, enquanto subsistam, bens jurídicos protegidos pela Convenção Interamericana. O desaparecimento forçado, de acordo com as mais diversas jurisprudências, constitui diversas ofensas a direitos fundamentais. Pois bem, já que um dos objetivos do desaparecimento forçado é impedir o exercício dos recursos legais e das garantias processuais pertinentes quando uma pessoa tenha sido submetida a sequestro, detenção ou qualquer forma de privação da liberdade, a Corte conclui que não há dúvidas quanto aos fatos do desaparecimento forçado dos integrantes da Guerrilha do Araguaia, nem da responsabilidade do Estado brasileiro e, que é seu dever a investigação e punição de violações de direitos humanos, usando dos demais instrumentos jurídicos internos para a realização de tais atos. 


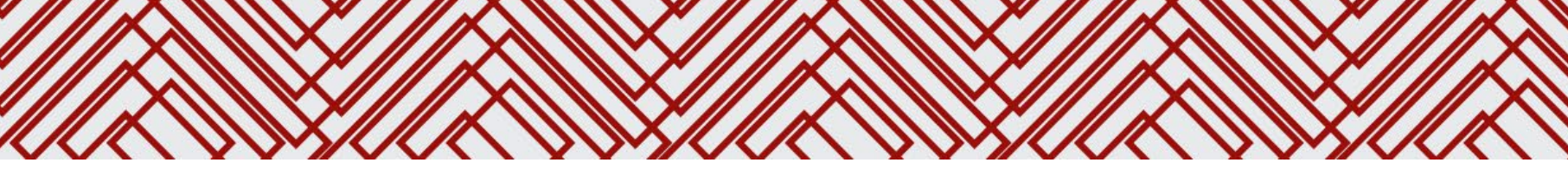

Recentemente, em 2013, o Senado Federal brasileiro aprovou a tipificação do desaparecimento forçado de pessoas, porém, esse projeto ainda precisa de análise da Câmara dos Deputados. Posteriormente, o decreto $\mathrm{n}^{\mathrm{o}}$ 8.767, de 11 de maio de 2016, sancionado pelo ex-presidenta Dilma Rousseff, ainda depende "de sujeição à aprovação do Congresso Nacional atos que possam resultar em revisão da Convenção ou que acarretem encargos ou compromissos gravosos ao patrimônio nacional". Todavia, as modificações não parecem resultar em um grande esforço do Estado para com a tipificação do delito. Salientando a Corte que não basta apenas promover projetos de lei, mas assegurar sua efetiva sanção e validade para surgir efeitos no ordenamento jurídico. Em relação ao desaparecimento forçado, considera em sua sentença, que há dano à integridade psíquica e moral, pois, foram afetados tanto as pessoas que desapareceram quanto seus entes queridos.

A falta de esclarecimento das circunstâncias das mortes ocorridas, do desconhecimento de seu paradeiro e da impossibilidade de dar a seus restos o devido sepultamento, o Estado pagará indenização para suprir a falta de tantas respostas. A Comissão reconheceu a boa-fé do Estado em assumir sua responsabilidade, através de sua conduta de atuação por meio da Lei $\mathrm{n}^{\circ}$ 9.140/95, admitindo incumbência com relação a esses desaparecimentos e sobre a reprovação a tais conduta, de modo a reparar tantos os danos materiais como imateriais com relação às vítimas desaparecidas.

Continua o tribunal a respeito do direito à liberdade de expressão e de pensamento, se restringem "não apenas o direito e a liberdade de expressar seu próprio pensamento, mas também o direito e a liberdade de buscar, receber e divulgar informações e ideias de toda índole" (CIDH, 2010, p. 75), além de estipular que o artigo 13 da Convenção tutela o direito de toda pessoa de solicitar o acesso à informação sob o controle do Estado, com as exceções permitidas sob o regime de restrições da Convenção, ou seja, ampara o direito das pessoas de receber essa informação e a obrigação positiva do Estado de fornecê-la.

Há de se salientar que existe uma concordância quase unânime dos Estados que compõem a OEA sobre a necessidade do acesso à informação pública. A Corte Interamericana determinou que, em uma sociedade democrática, é indispensável que as autoridades estatais sejam regidas pelo princípio de máxima divulgação, que estabelece a presunção de que toda informação é acessível, inclusive, para os familiares de vítimas de violações de direitos humanos. Entendendo assim, que o Estado não pode amparar-se na falta de prova da existência dos documentos solicitados. Ao contrário, deve fundamentar a negativa 
a prestar a informação, demonstrando que adotou todas as medidas a seu alcance para comprovar que, efetivamente, a informação solicitada não existia.

Com objetivo de averiguar, minuciosamente, a responsabilidade internacional do Estado brasileiro por violações aos direitos à vida, integridade e à liberdade, como também o reconhecimento da personalidade jurídica, a Corte faz a análise com base em provas de fatos comprovados. Reconhecendo que o desaparecimento forçado se constitui de múltiplas violações aos direitos previsto na Convenção Americana, tendo como elementos a privação de liberdade; intervenção direta de agentes ou sua aquiescência e a negativa de reconhecer a detenção e revelar o paradeiro da pessoa.

Quanto a tudo exposto, é reconhecido por jurisprudência da Corte que violação permanente perdura enquanto não for conhecido o paradeiro ou os restos da vítima, dirimindo que todos devem ter acesso às informações, exercendo o direito fundamental de acesso à informação, por ser um direito inerente à democracia, presumem-se pública todas as informações acessíveis a qualquer pessoa, mas, reconhece não ser um direito absoluto, podendo estar sujeito a restrições. Contudo, para restringir devem estar previstos em lei, assegurando que não fique no arbítrio do Poder Público. E quando houver a negação de acesso a determinada informação, o Estado deve motivar e fundamentar, ficando a seu cargo o ônus da prova referente à impossibilidade de revelar a informação e, ante a dúvida ou o vazio legal, deve prevalecer o direito de acesso à informação.

Ademais, a responsabilidade internacional do Brasil sofre empecilhos com base na Lei de Anistia, promulgada em 1979, que afastou internamente a responsabilidade de investigar as violações aos direitos humanos durante o regime militar. A Figura da anistia já foi declarada pela Corte incompatível com a Convenção Americana, por violar o dever internacional do Estado de investigar e sancionar as violações. Mas, diante uma ADPF, o STF reconheceu a constitucionalidade da referida lei e recepcionada pela Constituição, portanto declarou improcedente a arguição. Para a Corte a obrigação de investigar as violações são medidas positivas que os Estados devem adotar para garantir os direitos previstos pela Convenção. Além disso, é obrigação do direito internacional, advindas de todos os órgãos internacionais de proteção aos direitos humanos, processar e determinar a responsabilidade penal dos autores das violações.

Neste sentido, reconhece o Tribunal que o poder judiciário diante dessa situação seria obrigado a realizar o "controle de convencionalidade", entre as normas internas e a 
Convenção Americana, levando em consideração a interpretação da corte sobre a convenção. Contudo, este controle não foi realizado pelo Estado, pois a decisão do STF confirmou a interpretação da Lei de Anistia sem considerar as obrigações internacionais do Brasil derivadas do Direito Internacional.

Por fim, refutando a alegação de afetar o princípio da legalidade, a Corte, conforme salientado acima, reconhece ser um crime permanente ou contínuo, motivo pelo qual os efeitos do ilícito continuam, não estaria, assim, aplicando retroativamente a punição pelo delito de desaparecimento forçado.

\section{Recomendação ao Estado}

A Corte após analisar todos os acontecimentos e apontamentos de ambas as partes do presente caso, proferiu recomendações ao Estado, como forma de diminuir as consequências e sanar os danos e violações ocorridas.

Primeiramente foi recomendado que o Estado cumprisse com a obrigação de investigar de modo completo, efetivo e imparcial os desaparecimentos forçados do presente caso, a fim de identificar os responsáveis intelectuais e materiais dessas violações e sancioná-los criminalmente, não podendo aplicar a Lei de Anistia em benefício dos autores, bem como nenhuma outra disposição análoga como, prescrição, irretroatividade da lei penal, coisa julgada ou qualquer excludente similar responsabilidade para eximir-se dessa obrigação.

Além da investigação, há a determinação de que o Brasil intensifique, com recursos financeiros e logísticos, os esforços já envidados na busca e sepultamento das vítimas desaparecidas, cujos restos mortais ainda não tenham sido encontrados ou identificados, assim como a identidade dos restos localizados em missões anteriores na região do Araguaia e que sejam entregues rapidamente aos familiares, mediante prova do parentesco.

A corte ordenou como outra forma de reparação que o Estado providenciasse assistência médica e psicológica de forma gratuita e imediata, adequada e efetiva. Neste caso, por meio das instituições públicas especializadas de saúde, às vítimas que solicitarem e caso o Estado não disponibilize de instituição pública competente para o fazer, deverá recorrer a instituições privadas. Para receber todas essas providências a vítima interessada tem prazo de 6 meses para comunicar ao Estado sua intenção de receber atendimento psicológico ou psiquiátrico.

Ademais, foi solicitado que o Estado publicasse a presente sentença em Diário Oficial, devendo também reconhecer internacionalmente sua responsabilidade, visto que só o fez em 
âmbito interno, relacionado ao desaparecimento forçado, assegurando a não repetição dos fatos ocorridos neste caso. Foi considerado importante também que fosse criada uma Comissão da Verdade, para cumprir a obrigação do Estado de garantir o direito de conhecer a verdade sobre o ocorrido, entretanto isto não substitui a obrigação do Estado de promover a verdade e assegurar a determinação judicial de responsabilidades individuais, através dos processos judiciais penais.

Outro modo imprescindível de reparação é através das indenizações. O Estado anteriormente já vinha fazendo isto através de um processo administrativo que determinou uma indenização "a título de reparação" pelos desaparecimentos forçados ou mortes das vítimas diretas, considerados razoáveis pela corte tanto em relação ao dano material, quanto imaterial, entretanto caso haja familiares que não o receberam é estipulado o prazo de 6 meses para que façam jus a isto.

Por fim, o Tribunal recomendou que o Estado arque com as custas e despesas do processo, arbitrados por equidade. Toda a contabilização constatou que os representantes obtiveram diversos gastos relacionados ao recolhimento de prova, transporte, serviços de comunicação, na tramitação interna e internacional do presente caso e em vista de tudo isso o Estado é ordenado a pagar 45 mil dólares a favor do Grupo Tortura Nunca Mais, da Comissão de Familiares de Mortos e Desaparecidos Políticos de São Paulo e do Centro pela Justiça e o Direito Internacional, respectivamente, a título de custas e gastos.

\section{REFLEXÕES ACERCA DO CASO}

Torna de enorme valia, desenvolver um diálogo com outras violações no território brasileiro. Primeiro caso de violação e talvez um dos mais graves da história da humanidade, é o "Holocausto Brasileiro" 15 , o "depósito" de pessoas que foi o Hospital Colônia, que chegou a registrar mais de 60 mil mortes (ARBEX, 2013), após o Estado não controlar as internações que ali eram feitas. Destarte, as internações compulsórias pelas políticas de profilaxia da hanseníase, que através da Lei 610/49 legitimou as inúmeras violações aos direitos dos indivíduos portadores da doença e da separação de seus filhos. E em consequência disto os inúmeros episódios de torturas sofridos por eles. O que se destaca desta lei é em seu artigo nono autorizar a internação de pessoas que "não puderem obter recursos necessários à própria subsistência, ou forem portadores de estigmas impressionantes de lepra” (BRASIL, 1949).

\footnotetext{
${ }^{15}$ Definição dada no livro de mesmo título pela autora Daniela Arbex.
} 


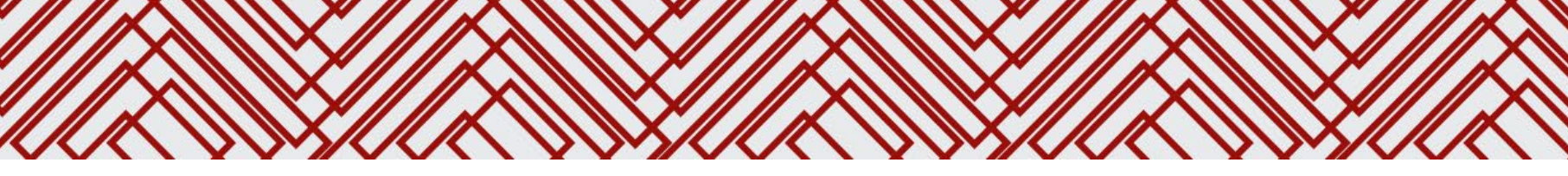

Há outras violações e outras condenações brasileira nos organismos internacionais, diante disso, requer uma compreensão das razões dessas ações estatais, uma vez que o período da ditadura militar foi intensificado muitas violações a direitos humanos. É notável que as políticas que legitimaram essas ações estão cobertas de ideologias fascistas, e para lucidar essas ações, é crucial buscar as concepções de fascismo. Apesar de sua difícil definição, englobando muitas concepções e sentidos, é um fenômeno que não pode ser analisado por uma estática do movimento, e sim seria necessário contrastar o fundamento ideológico com as práticas (MONTERIO, 2018). Deste modo, o fascismo apresenta uma forma de imposição do Estado sobre o indivíduo, por ser um movimento anti-individualista, ou seja, somente aceitavam o indivíduo quando os interesses coincidissem com os do Estado (MUSSOLINI, $2020)^{16}$.

Nesta esfera, o fascismo pode ser desenvolvido estruturalmente como ideologia enraizada em todo corpo social, como também por meio de um fascismo do apartheid social ${ }^{17}$, em que o Estado age fascistamente nas zonas selvagens, como predador, sem nenhuma veleidade de observância, mesmo aparente, do Direito (SANTOS, 1998). Evidenciando a marginalização das pessoas contrárias as suas ideologias.

Resta claro, que as ações estatais que eliminaram os guerrilheiros tinham raízes das ideologias fascistas, na medida que eliminaram aquilo que fosse contrário às ideias do Estado.

\section{CONCLUSÃO}

O Brasil sendo signatário da Convenção Americana de Direitos Humanos se compromete a respeitar e garantir os direitos básicos de todos sob a sua jurisdição, a punir as violações contra os direitos fundamentais, e a adotar as disposições de direito interno que sejam necessárias para que tais direitos sejam efetivados. Além disso, o país também reconhece a competência da Comissão e da Corte Interamericana para julgar casos de violação de direitos humanos que ocorram em seu território.

Como já restou provado no decorrer do caso Gomes Lund, a alegação feita pelo Estado de que a Corte não teria competência para julgar casos ocorridos anteriormente ao ano de 1998 não prosperou, já que os desaparecimentos forçados, apesar de terem sido provocados antes da submissão do Brasil a jurisdição da Corte, são crimes que se perpetuam no tempo,

\footnotetext{
${ }^{16}$ Livro "A Doutrina do Fascismo" está sendo publicado por algumas editoras, usamos a publicação da Lebooks. 17 A "segregação social dos excluídos, por meio de uma cartografia urbana dividida em zonas selvagens e civilizadas. As selvagens são as zonas do Estado de natureza hobbesiano. As civilizadas são as zonas do contrato social; vivem sob a constante ameaça das selvagens." (SANTOS, 1998)
} 
haja vista que as 62 pessoas tidas como desaparecidas políticas ainda não tiveram seus restos mortais encontrados.

Outrossim, é importante destacar que várias outras preliminares foram arguidas pelo Estado brasileiro, também com o objetivo de descaracterizar a competência da Corte no julgamento dos desaparecimentos ocorridos na região do Araguaia. Apesar disso, as preliminares arguidas foram refutadas e o Brasil foi condenado pela Corte Interamericana a, dentre outras medidas, determinar a responsabilidade daqueles que estiveram envolvidos com os desaparecimentos políticos.

O Estado brasileiro, portanto, foi considerado responsável por desaparecimento forçado, por violação ao direito à vida, à integridade e à liberdade pessoal, à garantia e proteção judicial, à liberdade de pensamento e expressão e ao direito de buscar e receber informações. Ademais, o país também foi responsabilizado pelo descumprimento da obrigação de adequar o ordenamento interno à Convenção, sendo condenado a investigar de maneira mais efetiva e imparcial os eventos relacionados a Guerrilha do Araguaia, indenizar e prestar assistência médica às vítimas e seus familiares e a adequar as normas de direito interno, para que a Lei da Anistia brasileira não seja mais um impasse na responsabilização dos culpados e a tipificação do crime de desaparecimento forçado.

Entretanto, desde de a condenação pela Corte em 2010 o Brasil cumpriu somente com a reparação pecuniária. O Projeto de Lei 301/2007 apensado ao Projeto 4.038/2008, que define os crimes de genocídio, de guerra e contra a humanidade, dentre eles o de desaparecimento forçado, ainda está aguardando a apreciação do Plenário. Além do mais, é possível identificar uma certa resistência das cortes domésticas em efetivar o cumprimento da sentença internacional, especialmente por conta da posição do Supremo Tribunal Federal, que na ADPF 153 considerou constitucional a Lei da Anistia, mesmo após o pronunciamento da Corte Interamericana declarando que as leis de auto anistia são inconvencionais. Diante disso, foi impetrada uma nova ADPF, de número 320, pedindo o reconhecimento pelo Supremo de que a Lei de Anistia não se aplica aos crimes de graves violações de direitos humanos cometidos por agentes públicos, mas, o seu julgamento é aguardado desde 2014.

Esses fatos demonstram, infelizmente, a falta de comprometimento do Estado brasileiro com a suas obrigações perante o sistema americano de proteção ao direitos humanos, além de um descaso contínuo em relação aos direitos fundamentais, especialmente no que se refere aos atos ocorridos durante a Ditadura Militar, que assim como os do Caso 
Gomes Lund, continuam sem reparações, pois a Lei da Anistia impede a responsabilização dos agentes públicos envolvidos em práticas de tortura, prisão arbitrária e até mesmo homicídio, perpetuando as violações ao direito à vida, à liberdade de expressão, à informação, à reparação, à memória, à garantia e proteção judicial, dentre outros.

Portanto, cumpre ressaltar que através do Controle de Convencionalidade é possível constatar clara inadequação da Legislação interna brasileira a Legislação Internacional, haja vista que crimes como o de desaparecimento forçado são considerados crimes contra a humanidade, tendo sua proibição, no âmbito internacional, tratada como norma de jus cogens.

Apesar de até o momento não ter surtido todos os seus efeitos, é possível concluir que a condenação do Brasil pela Corte Interamericana apresentou ser um marco na história do país, já que a responsabilidade do Estado pelo ocorrido foi auferida, tendo sido estabelecido internacionalmente a impossibilidade de leis de anistia nacionais tornarem impuníveis crimes contra a humanidade.

\section{REFERÊNCIA}

ARBEX, Daniela. Holocausto brasileiro: vida, genocídio e 60 mil mortes no maior hospício do Brasil. São Paulo: Geração Editorial, 2013.

BRASIL. Lei $\mathrm{n}^{\circ}$ 610, de 13 de janeiro de 1949. Fixa normas para a profilaxia da lepra. Rio de Janeiro, RJ, 13 jan. 1949. Disponível em:http://www.planalto.gov.br/ccivil_03/LEIS/19301949/L0610impressao.htm. Acesso em: 8mar. 2020.

CIDH. Caso 11.552, Julia Gomes Lund e outros (Guerrilha do Araguaia). Comissão Interamericana de Direitos Humanos contra a República Federativa do Brasil. Washington, D.C., 2009.

CONVENÇÃO Americana sobre Direitos Humanos. São José, Costa Rica, 22 de nov. 1969. Disponível em: <https://www.cidh.oas.org/basicos/portugues/c.convencao_americana.htm>. Acesso em: 10 ago. 2020.

KAPPES, Jefferson. A GUERRILHA DO ARAGUAIA: a luta armada nos campos e suas consequências históricas. A LUTA ARMADA NOS CAMPOS E SUAS CONSEQUÊNCIAS HISTÓRICAS. 2017. Orientada por: FÁBIO CARMINATI. Disponível em: https://rd.uffs.edu.br/handle/prefix/1152. Acesso em: 05 maio 2017.

LIMA Simone Alvarez; VAL, Eduardo Manuel. ANÁLISE DO CASO LUND VERSUS BRASIL APÓS CINCO ANOS DA CONDENAÇÃO E A ATUAL INEFICIÊNCIA DO TRANSCONSTITUCIONALISMO. Ius Gentium. Curitiba, vol. 8, n. 2, p. 110-133, jul./dez. 2017.

MONTEIRO, Gustavo Feital. Definindo o Fascismo: comparando análises e interpretações. 


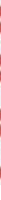

FEITAL MONTEIRO, G. Definindo o Fascismo: comparando análises e interpretações. Faces de Clio, v. 4, n. 8, p. 60-80, 3 jul. 2019.

MUSSOLINI, Benito. A doutrina do fascismo. LeBooks Editora, 2020. 
visando proporcionar o devido aprendizado, a equipe fará, também, a análise crítica do evento, na conclusão da presente dissertação.

\section{DO PROCEDIMENTO JUNTO À COMISSÃO}

Em outubro de 2002, a Comissão Interamericana recebeu a petição inicial instruída pelo Movimento Nacional de Direitos Humanos/Regional Nordeste, pelo Gabinete de Assessoria Jurídica das Organizações Populares (GAJOP), pelo Conselho Indigenista Missionário (CIMI) e pela Justiça Global.

Após análise, a Comissão emitiu parecer admitindo a petição inicial e após os trâmites previstos pela Convenção Americana de Direitos Humanos (Pacto de San José da Costa Rica) expediu relatório de mérito sobre o evento, que dentre os diversos pontos apontados destacase: I) A responsabilização internacional do Estado Brasileiro pela violação ao direito à propriedade, bem como às garantias e à proteção judicial, como por exemplo, o direito a ser ouvido dentro de prazo razoável por juiz competente.; II) Uma série de recomendações, das quais se cita: a) Medidas para saneamento do território indígena dos povos Xucuru; b) A definição de ações judiciais que envolvam os territórios atinentes ao grupo indígena; c) A reparação dos danos causados pelas violações aos Direitos Humanos, e por fim; d) Medidas protetivas visando assegurar os direitos indígenas da tribo Xucuru em eventuais demandas futuras.

Nada obstante, em momento subsequente à publicação das recomendações e do parecer de conteúdo meritório, a Comissão notificou o Estado Brasileiro sobre sua decisão, concedendo prazo para que o Estado cumprisse com as suas obrigações no âmbito interno.

A notificação não foi atendida. Assim, frente à negativa recebida, a Comissão, utilizando-se de suas prerrogativas, apresentou o caso à Corte Interamericana, relatando as omissões e inércias do País, requisitando que o procedimento fosse instaurado junto ao órgão judicial, dotado de jurisdição para Julgamento.

\section{DO PROCEDIMENTO JUNTO À CORTE}

A apresentação do caso pela Comissão foi fielmente aceita pela corte, que em um primeiro momento, notificou novamente as partes, sendo que a parte acusada (Estado Brasileiro), dentro do prazo estipulado, ofertou contestação aos fatos alegados pela Comissão além de ter interposto, no mesmo documento, cinco exceções preliminares. 


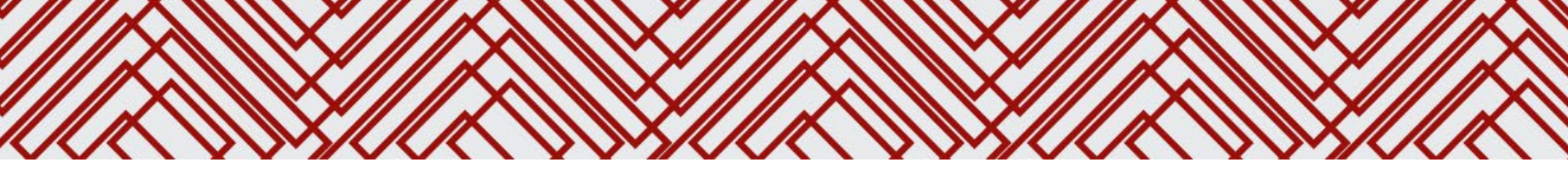

A Corte ainda reiterou a ideia de que apesar de sua competência para declarar violações da Convenção Americana sobre Direitos Humanos e de instrumentos do Sistema Interamericano, poderia igualmente, se utilizar de outros tratados para analisar o alcance e o conteúdo dos direitos da convenção, razão pela qual indeferiu mais uma das pretensões do acusado.

Por fim, quanto à exceção preliminar que arguiu pela falta de esgotamento dos recursos internos, a Corte considerou que um dos requisitos para admissibilidade da petição junto à Comissão trata-se justamente da comprovação pelo Estado, de que os recursos internos se esgotaram, tendo para tanto, que apresentar argumentos fáticos relevantes que tornem incontroversos a decisão de inadmissão da petição.

Como bem exposto no relatório enviado pela Comissão à Corte, o Estado brasileiro não especificou os recursos internos pendentes de esgotamento, ou aqueles que eventualmente estariam em curso, e ainda assim, deixou de expor as razões pelas quais consideravam que eram procedentes e efetivos no momento processual oportuno, de forma precisa e específica. Nestes termos a Corte considerou improcedente, a quinta, e última, preliminar.

Em breve síntese do necessário, após analisar as cinco exceções preliminares pleiteadas, pelo ora acusado, a Corte apenas deu parcial provimento à exceção preliminar relativa à ratione temporis, observando que seriam objeto de julgamento apenas os fatos ocorridos após a adesão em 1988 do Estado Brasileiro à Jurisdição da Corte, fato que não impediu a continuação do caso, vide o que se demonstrará a seguir.

\section{PROVA}

Quanto à produção de provas, a Corte recebeu diversos tipos de provas documentais, apresentadas pelo Estado, pelos representantes, e pela Comissão. Além dos documentos, também foram pleiteadas provas testemunhais e periciais pelas partes.

Ao receber as provas nesta fase processual, a Corte analisou a admissibilidade delas, considerando sua forma, conteúdo e objeções feitas pelas partes contrárias. Caso as provas apresentadas pelo Estado e pela Comissão preenchessem os requisitos de admissibilidade, elas seriam admitidas e passariam a posterior avaliação de mérito e aplicação no caso fático. Porém, os representantes das supostas vítimas não apresentaram suas petições, com argumentos e provas, em momento processual oportuno, como consequência, sofreram os efeitos da preclusão. 


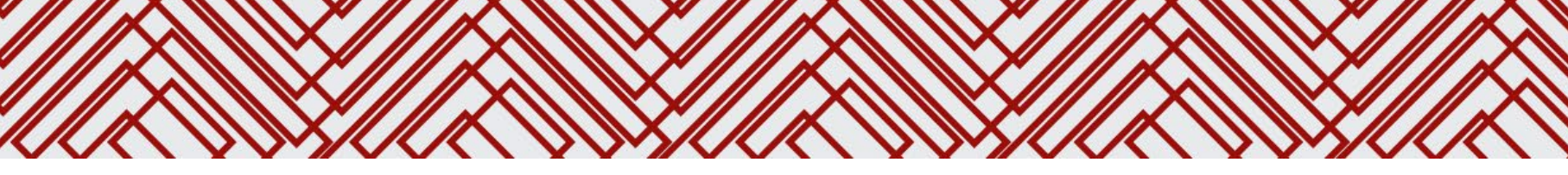

Com isto, a Corte ficou impedida de avaliar e considerar qualquer alegação ou prova dos representantes que acrescentassem novos direitos, fatos, ou pretensões, diferentes daquelas já pleiteadas pela Comissão.

\section{FATOS}

O Povo Indígena Xucuru, atualmente denominado de Xucuru de Ororubá, tem sua história registrada desde o século XVI, pelos primeiros ocupantes do Estado de Pernambuco. Atualmente, a tribo tem em torno de 7.726 indígenas, espalhados por um território de aproximadamente 27.555 hectares, no município de Pesqueira - PE.

A seguir será exposto uma contextualização histórica dos direitos indígenas no Brasil, bem como o caso fático dos índios Xucuru.

$\mathrm{O}$ direito se manifestou nas tribos de maneira consuetudinária, sendo certo que os combates como direito positivada, se diferem substancialmente dos costumes indígenas. Segundo RIBEIRO ,2014, p - 7 “Locais onde as pessoas solucionam seus conflitos a partir de usos e costumes consolidados em longo tempo de aplicação de uma visão própria de mundo (elementos imprescindiveis à legitimação do Direito Consuetudinário)",

De forma a reiterar o que foi exposto no tópico anterior, a Corte Interamericana de Direitos Humanos, respeitando sua devida competência temporal, só poderia levar em consideração, para o fim de julgar o Estado brasileiro, os fatos ocorridos após a data de ratificação de sua competência contenciosa, ou seja, após 10 de dezembro de 1998.

A Constituição Federal de 1988 assegura, em seu artigo 20, o direito dos povos indígenas sobre suas terras, territórios e recursos, tendo sua posse permanente bem como o usufruto exclusivo dos recursos nelas existentes.

Tal direito é concedido através do processo de demarcação de terra, que é compreendida por cinco etapas, sob orientação da FUNAI em conjunto com o Presidente da República.

A primeira etapa consiste na identificação e delimitação da área indígena. Nela, devem ser observados aspectos como a extensão territorial, bem como se há a devida e real ocupação indígena, que é realizada por estudo antropológico qualificado.

Após isso, na segunda etapa, é feito o processo da declaração da demarcação, em que a FUNAI encaminha os estudos para o Ministério da Justiça, que analisa os possíveis vícios 
de procedimentos e objeções, que, caso aprove o procedimento, determina a demarcação administrativa da área.

Continuando o procedimento, há a demarcação física, que é a terceira etapa, em que são demarcadas as áreas descritas no relatório realizado previamente.

A quarta etapa é a homologação, que é feita mediante um decreto presidencial, reconhecendo juridicamente a nova terra indígena.

Ao final do processo, ainda há a quinta etapa, o registro, em que a FUNAI promove o registro imobiliário do território, em sua comarca, e na Secretaria do Patrimônio da União do Ministério da Fazenda.

O processo de demarcação do território indígena do povo Xucuru foi iniciado em 1989, e seguiu os procedimentos legais descritos acima. Foi feito o relatório, por parte de grupo técnico em 6 de setembro de 1989, aprovado pelo presidente da FUNAI e pelo Ministro da Justiça em 1992, concedendo assim, a posse permanente do território ao Povo Xucuru, que foi demarcada em 1995, com uma área de 27.555,0583 hectares.

No ano de 1996, foi promulgado o Decreto n ${ }^{\circ}$ 1775/96 pelo Presidente da República, que reconhecia o direito de terceiros interessados no território demarcado, a apresentarem objeções visando impugnar o processo de demarcação, argumentando pelo direito à propriedade e pelo direito à indenização de possíveis terras perdidas.

Após este decreto, houveram aproximadamente 270 objeções contra o processo de demarcação, que, a princípio, foram todos negados pelo Ministro da Justiça em 1996.

Após ter sido declarada a improcedência das ações, os terceiros interessados, em 1997, apresentaram um Mandado de Segurança ao STJ, que foi concedido pelo tribunal, e novamente recusadas pelo Ministro da Justiça.

Anteriormente às ações citadas acima, em 1992, o proprietário de uma fazenda que havia sido ocupada pelos indígenas ingressou com uma ação de reintegração de posse, que foi decidida em 1998 pelo STJ, em favor dos ocupantes não indígenas.

Confira o relato feito por Edson Silva:

Além das ações judiciais, o processo de demarcação do território indígena foi marcado por muita violência, chegando ao seu ápice quando o Cacique Xicão, líder do povo Xucuru, foi assassinado a mando de um fazendeiro que tinha suas terras dentro do território pertencente à tribo. Na mobilização Xucuru na década de 1980, destacou-se Francisco de Assis Araújo, o Cacique "Xicão" como era conhecido. Além de ser uma liderança carismática para o seu povo, foi também uma expressiva e reconhecida liderança entre os demais povos indígenas no Nordeste, alcançando 
ainda uma considerável projeção no movimento indígena no país. Sob sua liderança os Xucuru pressionaram os órgãos públicos pelo reconhecimento de seus direitos 10 e a demarcação de suas terras. A atuação do Cacique Xicão provocou a ira dos fazendeiros, a oligarquia de Pesqueira, tradicionais invasores das terras Xucuru, financiadores de um pistoleiro que assassinou o Cacique em 20/05/1998. (SILVA, Edson, 2007, p. 9/10)

Enquanto tais acontecimentos se desenrolaram, o processo demarcatório ainda estava em trânsito, em 2001, o Presidente da República, expediu o decreto que homologou a demarcação do território. E somente em 2005, foi executada a titulação do território como propriedade da União para posse permanente do Povo Indígena Xucuru.

Porém, apesar de findado o processo de demarcação territorial com o devido procedimento legal, em 2014, a sentença da ação de reintegração de posse, citada acima, adquiriu força de coisa julgada, mesmo após inúmeros recursos e apelações por parte da FUNAI, do MPF, do próprio Povo Indígena Xucuru e da União.

Em decorrência disso, no ano de 2016 a FUNAI interpôs uma ação rescisória para anular a sentença em desfavor dos indígenas. A ação ainda continua pendente, dependendo de uma nova decisão do Tribunal Regional Federal.

Além dessa ação de reintegração de posse supracitada, existem diversas outras pleiteando o mesmo direito, interpostas por diversos proprietários que perderam suas terras com a demarcação indígena. Ademais, também existem diversas ações de cobrança de indenização por perdas e danos contra a FUNAI e o Estado, que somam um montante de R\$ 1.385.375,86 (Um milhão trezentos e oitenta e cinco mil reais e oitenta e seis centavos).

Em decorrência dos diversos embates judiciais e extrajudiciais, o contexto da demarcação das terras do Povo Xucuru é marcado por violência. O embate sobre a demarcação é tão intenso, que existem até indígenas Xucuru contrários à ela, em favor dos latifundiários e do município de Pesqueira.

Após a morte do Cacique Xicão líder da Tribo Xucuru, seu filho, Marquinhos, assumiu a liderança do povo, e enfrentou diversos tipos de ameaças e inimigos, a fim de garantir a devida demarcação e o direito da tribo indígena. Devido a sua luta incessante, sofreu um atentado contra sua vida, que resultou na morte de outros dois indígenas, o que não obstou o seu objetivo: lutar e defender os direitos de seu povo.

Com isso, em 2008, o Cacique Marquinhos foi incluído no Programa de Proteção aos Defensores dos Direitos Humanos de Pernambuco; e o Conselho Nacional dos Direitos da 
Pessoa Humana criou uma Comissão Especial para investigar a tentativa de homicídio contra o líder indígena, e evitar que fatos como esse voltem a acontecer no futuro.

As alegações de fato expostas até o presente momento servem de base para que se contextualize a análise de mérito feito pela Corte interamericana, em consonância com o que será exposto no tópico subsequente.

Em vias de se analisar as questões supra descritas, o Povo Indígena Xucuru sofreu durante toda a sua história diversos atentados à sua existência e a seu território.

O procedimento instaurado frente ao mecanismo de proteção regional de direitos humanos, tornou-se instrumento imprescindível para garantia de sua tutela e respeito.

Assim, passa-se a conferir o relatório de mérito proferido pela Corte.

\section{MÉRITO}

No que concerne ao mérito, a Corte Interamericana de Direitos Humanos analisou possíveis violências à propriedade, às garantias judiciais e à proteção judicial ao Povo Indígena Xucuru. Desse modo, são explanados os argumentos das partes e da Comissão Interamericana de Direitos Humanos, em seguida das considerações da Corte, dentro do contexto fático supracitado e das normas da Convenção Americana.

A CIDH alega nos autos que a propriedade do território indígena se legitima pela posse e tradição no uso dos recursos da terra em que estão inseridos, independente de título de reconhecimento de propriedade estatal, cuja matéria é delimitada pelo artigo 21 da Convenção Americana.

Faz-se mister ter em mente o conceito de propriedade sob diferentes óticas para a melhor compreensão do caso em tela. O ilustre estudioso do ramo do Direito Civil, Carlos Roberto Gonçalves, em sua obra doutrinária acerca de Direito das Coisas, correlacionou o artigo 1228 do Código Civil, que conceitua propriedade dentro do ordenamento jurídico brasileiro, com o antigo Direito Romano. Dentro deste ordenamento, para constituir uma propriedade o sujeito deve deter 4 elementos: jus utendi, fruendi, abutendi e rei vindicatio. $\mathrm{Ou}$ seja, o proprietário deve poder usar, fruir, abdicar e reivindicar a posse de sua propriedade do modo que melhor the convir.

Ora, no caso dos Xucurus há nitidamente a reunião desses 4 elementos. Veja os fatos, esse grupo indígena, formado por aproximadamente 6 mil habitantes, reside na mesma região da Serra do Ororubá há mais de um século. É um longo e contínuo período de usufruto que 
ilustra os 2 primeiros elementos de propriedade do Direito Romano e também do artigo 1228 do Código Civil, porém ainda insuficientes para caracterizar uma propriedade plena, uma vez que estes elementos também podem ser observados na posse. Em sequência, nota-se que ao longo desse século de habitação, apenas na década de 1980, com a intensificação da turbação do território indígena por parte dos latifundiários locais, os Xucurus viram-se obrigados a instaurar um processo administrativo de demarcação da sua área, algo que até então era desnecessário. Evidencia-se assim o rei vindicatio para salvaguardar a área, além de em nenhum momento ocorrer a abdicação de suas terras.

Ademais, há a evidente necessidade de demarcação de seus territórios pelo fato de que este é o único meio de salvaguardar a existência desse povo, que tem sua propriedade coletiva turbada por fazendeiros latifundiários da região. Dessa forma, o Brasil foi inerte ao solucionar o problema em questão, já que em 1992 e 2002 foram interpostas ações nessa matéria e não houve uma resolução efetiva.

Portanto, é nítido a legitimidade da propriedade do povo Xucuru dentro da delimitação do artigo 21 da Convenção Americana bem como dentro dos parâmetros do artigo 1228 do Código Civil, sendo assim evidenciada a convergência entre as legislações nacional e internacional.

Carlos Roberto Gonçalves verbaliza o conceito de direito de propriedade:

O poder jurídico de atribuído a uma pessoa de usar, gozar e dispor de um bem, corpóreo ou incorpóreo, em sua plenitude e dentro dos limites estabelecidos na lei, bem como de reivindica-lo de quem injustamente o detenha. (GONÇALVES, 2020, p. 224-225)

A despeito de garantias e proteção judicial, a Comissão entende que não é razoável para o caso em comento, uma demora que atingiu o prazo de aproximadamente 20 anos para o correto posicionamento e demarcação de terras indígenas, o que configura uma violação do país aos artigos 25 e 8.1 da referida Convenção.

Os representantes, por sua vez, reiteram que nunca existiu uma coexistência pacífica na região, muito pelo contrário, há nesse território 6 (seis) ocupantes não indígenas, o não recebimento de indenizações referentes a antigos ocupantes, além da falta de soluções para ações de reintegração de posse.

Dessa forma, evidencia-se a falta de estabilidade e segurança do povo Xucuru, além da inércia estatal, o que viola não apenas os já mencionados artigos 8 e 25 da Convenção Americana, como também os artigos 1.1 e $2^{\circ}$. 


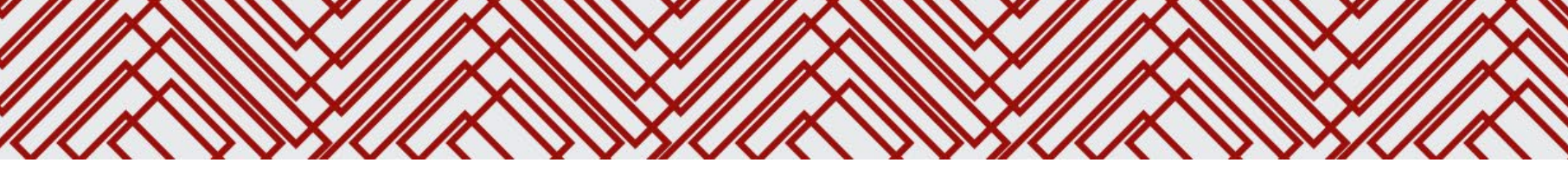

Por outro lado, o Estado, garante que não houve no processo demora injustificada, que a maioria substancial de indenizações já foram acertadas, cerca de $84 \%$, e ressalta que o processo de demarcação de terras é de ofício estatal, de modo que os indígenas não se encontram no polo ativo desse processo. Outro fato apontado, é que foi realizada uma inspeção no território, que constatou uma convivência pacífica nesse território, e que são poucas as parcelas de terra que não estão em posse do povo Xucuru. Conclui-se assim, o Estado, que houve respeito a todos os artigos da Convenção Americana mencionados acima, uma vez que neste ponto de vista, houve respeito aos direitos e disposições do ordenamento jurídico interno, às garantias e proteções judiciais, e ainda à propriedade coletiva.

A Corte Interamericana de Direitos Humanos emitiu suas considerações em função dos casos acima, e inicia-se pela questão do direito à propriedade sob a luz da Convenção Americana e suas normas de interpretação estabelecidas no artigo 29.b. A Corte compreende o pleno direito do povo Xucuru à propriedade coletiva em questão, com base no artigo 21 da Convenção Americana e também do artigo 169 da Organização Internacional do Trabalho, tal como a necessidade de se materializar esse direito com a demarcação para conferir segurança jurídica.

Reitera-se a necessidade de o Estado garantir a segurança jurídica e a propriedade coletiva, com a obrigação negativa de respeitar e a positiva de garantir o livre usufruto dos proprietários. Dentro da jurisprudência da Corte, pode-se afirmar que no embate instaurado entre propriedade individual e propriedade coletiva, como no conflito entre latifundiários e indígenas, há claramente uma posição favorável à coletividade em detrimento da posse individual, o que endossa a razão dos Xucurus. Ademais, não apenas a jurisprudência da Corte, mas também a própria Constituição Federal, que incumbe ao Estado o dever de garantidor de terras aos nativos, e o posicionamento do Supremo Tribunal Federal estão sendo feridos pelo país não estar tomando ações que sejam efetivas e condizentes com seu ordenamento jurídico.

Ao se remeter à demora processual no caso em questão, a Corte IDH analisou 4 elementos para chegar a uma conclusão. No primeiro aspecto, complexidade do assunto, de acordo com a jurisprudência da Corte, não foram detectados elementos que justificassem todo esse longo decurso de tempo. A Corte apenas concorda que o processo de desintrusão é complexo e demanda um longo tempo. Em seguida, fora analisada a atividade processual dos interessados, se as partes realizaram atos cabíveis no decorrer do processo. A Corte considerou que o Estado, através de suas instituições governamentais competentes, como a 
FUNAI, deveria comandar o processo de demarcação de terras, e não aguardar a intervenção dos indígenas no processo para começar a agir. Ademais, no que se refere a conduta, são identificados diversos momentos em que falta de interesse das autoridades públicas no andamento do processo, sendo que estas deveriam zelar pela garantia dos direitos aos indígenas. Por fim, é analisado o dano provocado pela situação jurídica, que foi considerado excessivamente danoso e desrespeitoso, principalmente sob o prisma dos artigos 8.1 e 1.1, com o longo período para o Estado reconhecer o território Xucuru oficialmente.

Vale ressaltar que as supracitadas normas internacionais da Convenção Americana têm caráter jus cogens, ou seja, são normas imperativas que devem ser fielmente tuteladas pelos Estados signatários. Assim, exige-se que todos os membros de convenções, pactos ou tratados internacionais, façam todas as adequações necessárias em suas legislações para a correta inclusão das normas internacionais em seus respectivos ordenamentos jurídicos. Portanto, o Estado parte que não observar em âmbito interno transgressões à Convenção Americana estão sujeitos à responsabilização internacional.

Como foi exposto anteriormente, o processo de demarcação do território dos Xucurus iniciou-se em 1980, e sem uma correta resolução do litígio na jurisdição brasileira, foi peticionado em 2002 junto à CIDH sua luta pelas terras pertinentes. Ao certificar que, de fato, houve violação pela justiça brasileira aos artigos 8.1 e 25.1 da Convenção Americana, é indiscutível o Brasil passível de punição internacional.

O Professor de Direitos Humanos Silvio Beltramelli Neto esclarece perfeitamente o modo como as normas internacionais vinculam seus membros:

\footnotetext{
Paradoxalmente, à vista das normas em vigor, não há qualquer dúvida de que os Estados submetidos às instâncias internacionais protetoras dos direitos humanos estão obrigados, como já estudado, em absolutamente todas as suas instâncias (administrativas, legislativas e judiciárias) a respeitar, (não intervir), proteger (legislar e criar aparato que coíba as violações) e promover (adotar políticas que fomentem o gozo efetivo) as normas de DIDH que lhes sejam aplicáveis. (NET0, 2018, p.449)
}

Para findar a discussão a despeito da aplicabilidade de normas internacionais dentro do ordenamento jurídico brasileiro, o célebre Professor da Faculdade de Direito da Universidade de São Paulo Tércio Ferraz Jr. descreve com precisão sua hierarquia normativa:

Nesse âmbito, ainda há lugar para os tratados e as convenções celebrados entre os Estados e que, desde que aprovados no âmbito interno conforme procedimentos prescritos pelas respectivas constituições, adquirem o status legal, imperam como leis internas, de tal modo que, se são incompatíveis com leis ordinárias do país, as tornam revogadas conforme a regra estrutural da lex posterior. (JR., 2017, p.196) 


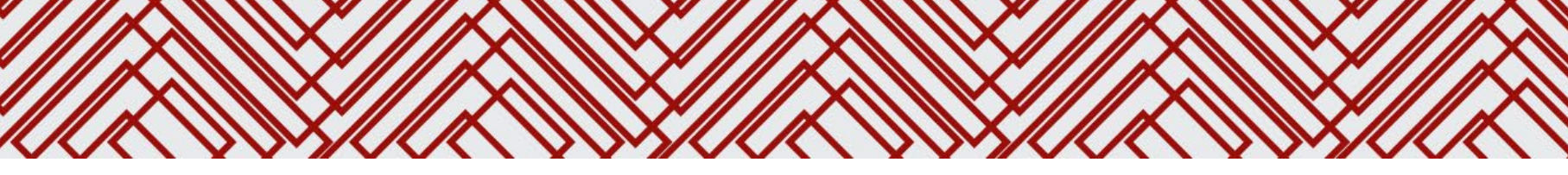

Desse modo, cessa qualquer hipótese de invalidade das normas da Convenção Americana e exclusividade da jurisdição nacional para solucionar o litígio. Em vista das transgressões à Convenção, inércia estatal e afronta aos Direitos Humanos do povo Xucuru, é dever da Corte IDH entrar em cena e intervir em favor da justiça que deve prevalecer no caso em estudo, o que corrobora a sentença da Corte.

Outro ponto contemplado no processo é do agravo à propriedade coletiva dos Xucurus, que evidenciado pela lentidão para a homologação e registro dos territórios indígenas, além de ações de reintegração de posse movidas por terceiros não indígenas que reivindicavam a área, possibilitou a permanência por maior tempo de não indígenas no território Xucuru. Esse aspecto tem, de fato, grande influência no xeque colocado à propriedade coletiva deles, o que representa infrações aos direitos de proteção e propriedade estabelecidos, respectivamente, nos artigos 25 e 21 da Convenção Americana.

Por outro lado, o Estado não foi responsabilizado por seu ordenamento jurídico interno ter normas incompatíveis com a Convenção Americana. Um eventual conflito entre norma interna e Convenção deveria ter sido arguido pela CIDH ou pelos representantes explicitamente, uma vez que isso não foi constatado nos autos do processo, o Estado deixa de ser responsabilizado pelo artigo $2^{\circ}$ da Convenção Americana, que dispõe:

Se o exercício dos direitos e liberdades mencionados no artigo 1 ainda não estiver garantido por disposições legislativas ou de outra natureza, os Estados Partes comprometem-se a adotar, de acordo com as suas normas constitucionais e com as disposições desta Convenção, as medidas legislativas ou de outra natureza que forem necessárias para tornar efetivos tais direitos e liberdades.

A Comissão e os representantes também consideraram a infração ao artigo 5.1 da Convenção Americana, ao entender que houve lesão à integridade psíquica e moral do povo Xucuru pela ineficaz proteção e reconhecimento do território indígena. Em contraponto, o Estado alega não haver um nexo causal entre violação de direito à propriedade e direito à integridade pessoal, e entende que não há conteúdo fático, denúncias e investigações suficientes para a responsabilização estatal.

A Corte IDH em seu parecer, em comunhão com o Estado, entende que a Comissão carece em não oferecer provas de violação à integridade pessoal, de modo a ser impossível a responsabilização do Estado, encerrando assim o mérito do caso.

Desta maneira, ao se remeter ao âmbito meritório do caso, a corte decidiu que as matérias concernentes ao direito à propriedade, garantias judiciais e proteção judicial mereciam prosperar quanto á alegações de fato pleiteadas pela Comissão. Todavia, ao se 
remeter a interpretação da matéria de direito á integridade pessoal, o Estado Brasileiro restou vencedor.

\section{DA SENTENÇA E DAS REPARAÇÕES}

Na íntegra da decisão, nota-se como fulcro o Art. 63.1 da Convenção Americana de Direitos Humanos, evidenciando na maneira de que, toda violação de obrigação internacional que tenha provocado dano, implica o dever de repará-lo adequadamente, requerendo, sempre que possível, a plena restituição (restitutio in integrum), consistente no restabelecimento do status quo anterior. Assim, conforme André de Carvalho Ramos (2005, p.67) preleciona: “ $A$ responsabilidade é característica essencial de um sistema jurídico, como pretende ser o sistema internacional de regras de conduta."

Ocorre que, na hipótese da incapacidade de seguir o referido princípio, - como acontece na quase integralidade dos casos -, o Tribunal determinará medidas para garantir os direitos violados com a consequente reparação das infrações ali causadas. Nesse ínterim, O tribunal internacional concluiu que o Povo Xucuru se apresentava como parte lesada, configurada a responsabilidade de reparação do Estado Brasileiro.

Deste modo, a título de medidas reparatórias, a priori, a Comissão solicitou que a Corte adotasse, com maior brevidade, as medidas necessárias para tornar efetivo o direito de propriedade coletiva e a posse do Povo Indígena Xucuru. Além disso, a obrigação de garantir aos membros da comunidade que possam continuar vivendo de maneira habitual e tradicional, conforme suas identidades, e, em segundo lugar, a promoção do encerramento de todas as ações judiciais interpostas por pessoas não indígenas a respeito de parte do território do povo Xucuru. Apesar das alegações feitas pelo Estado Brasileiro requisitando a improcedência das solicitações da comissão, os argumentos não prosperaram. O Estado fora condenado ao pagamento das custas processuais e à indenização compensatória coletiva.

Portanto, como exposto acima, o Estado Brasileiro findou-se para a Corte como responsável pelas violações, por decorrência de sentença penal condenatória. Isto posto, erudiu o estimado professor Ferreira Júnior (2019, p.32):

(...) as obrigações postas no artigo 1.1 da Convenção Americana implicam o dever dos Estados Partes de organizar todo o aparato governamental e, em geral, todas as estruturas mediante as quais se manifesta o exercício do poder público de maneira que sejam capazes de assegurar juridicamente o livre e pleno exercício dos direitos humanos.

Neste ínterim, a referida responsabilização estatal, tornou-se evidente, em: I) Garantir total direito de propriedade do Povo sobre seu território, de modo a não sofrerem mais 
quaisquer invasões, por parte de terceiros ou do próprio Estado, que possa depreciar a existência, o valor, o uso ou o gozo de seu território, nos termos do parágrafo 193 da presente Sentença do caso. II) promover a conclusão do processo de desintrusão do território indígena, III) promover o pagamento das indenizações e benfeitorias de boa-fé ainda pendentes, garantindo o domínio pleno do povo Xucuru, tudo fixado em prazo não superior a 18 meses IV) promover o pagamento das quantias fixadas a título de custas e indenizações por danos materiais, nos termos da sentença do caso e, V) no prazo de um ano, apresentar relatório sobre as medidas adotadas para seu cumprimento.

Por fim, ante o exposto, torna-se evidente pela sentença, que o Estado Brasileiro foi comprovadamente responsável pela violação: A) Do direito a garantia judicial de prazo razoável, B) Do direito a proteção judicial; C) Pela violação ao direito de propriedade coletiva.

Todavia, que o Estado não deverá ser responsabilizado pelo dever de adotar disposições do direito interno, assim como não se responsabiliza, igualmente pela violação ao direito de integridade pessoal.

\section{CONCLUSÃO}

O caso apresenta um grande feito, caracterizando a primeira vez em que o Brasil fora julgado pela Corte Interamericana de Direitos Humanos sobre a questão de demarcação de terras indígenas.

Como bem exposto durante todo o teor do trabalho, e analisando a decisão e as medidas tomadas tanto pela Corte como pela Comissão Interamericana, resta evidente que, no Brasil, o direito indígena é objeto de extrema negligência e retaliação dentro do ordenamento jurídico.

A decisão da corte, resumida nos termos da sentença prolatada em 2018, assegura grande avanço e esperança para as diversas populações indígenas que sofrem diariamente atentados contra seus direitos e sua própria existência.

Vale ressaltar que o problema de demarcação de terra indígena relacionado ao povo Xucuru não é um caso isolado. O modelo organizacional é falho, a FUNAI (Fundação Nacional do Índio) carece de poder e, em territórios mais afastados, dominados por latifundiários, torna-se difícil um diálogo sobre a posse. A legislação brasileira instituiu garantias aos indígenas, mas no mundo prático, não se vê tais fatos. Para isto é preciso que 
órgãos estatais mantenham suas funções mesmo com pressão e interferência de setores que não apoiam a causa indígena.

Observando esse caso isolado e o posicionamento da Comissão e da Corte, destacase que não é plausível uma demora de duas décadas para o correto posicionamento do Estado e a demarcação do território, sendo assim, o Estado também falha nos artigos 25 e 8.1 da referida Convenção.

Convém enaltecer a figura do cacique Francisco de Assis Araújo, conhecido como Chicão que lutou pelo seu povo e organizou uma batalha por suas terras. Assassinado por um grupo interno que cedeu ao mundo exterior, importunamente, pagou o preço por reivindicar o que pertencia ao seu povo.

Lamentável que tenha sofrido um golpe fatal de seus aliados, mas, tal situação, nos mostra como a ganância e a falta de instrução pode prejudicar um povo, e que se o Estado tivesse agido com uma eficácia maior, o desfecho dessa história poderia ter sido diferente.

O que não pode ser negado é, que o povo Xucuru, avançou e triunfou, mesmo com prisões e com a morte de Chicão. Nada disso barrou a luta para que expulsassem de suas terras 281 posseiros.

A condenação imposta ao Estado Brasileiro pela Corte interamericana, demonstra-se como importante precedente judicial para que os povos indígenas possam reivindicar o que é seu por direito.

Todavia, tendo em vista a grande falta de informação por parte dos povos indígenas, demonstra-se prudente que a sociedade brasileira, bem como os órgãos dotados de competência como o poder executivo e legislativo, se orientem de maneira a proteger esta parcela da população objeto de extermínio desde os períodos de colonização.

Trazendo para discussão os pontos cruciais de decisão da corte, deve ser imprescindivelmente reconhecido a fragilidade dos povos indígenas frente aos latifundiários e aos grandes donos de terra.

O Estado Brasileiro tem o dever de adotar em tempo razoável, medidas que possibilitem o respeito e a tutela das mais variadas tribos deste país. Para tanto vislumbra-se que a sentença proferida pela corte possa ser utilizada como precedente valioso ao Estado Brasileiro, uma vez que além de ter reconhecido a omissão, negligência e ineficácia de suas 
instituições, fez com que o Estado arcasse com grande prejuízo pecuniário e depreciação junto à comunidade internacional, no que se remete à proteção dos direitos indígenas.

Por fim, dirigindo a decisão ao cenário atual brasileiro, espera-se que não somente as instituições políticas e a administração pública em geral, se atentem aos direitos indígenas, mas também, a população.

O exercício da democracia e do respeito por parte do povo, configura-se como um dos mais importantes expoentes para a preservação dos povos indígenas, sendo observado que antes de tudo, todos somos iguais perante a lei, sem distinção de cor ou etnia, e que os direitos e deveres dos povos indígenas, em nada se diferem de qualquer civilização.

\section{REFERÊNCIA}

BIBLIOTECA DIGITAL DE PERIÓDICOS UFPR. O Desenvolvimento de Normas "Jus Cogens" em Relação ao Reconhecimento do Direito à Propriedade Coletiva dos Povos Indígenas à Luz da Sentença do Caso Povo Indígena Xucuru e seus Membros versus Brasil. Disponível em: https://revistas.ufpr.br/direito/article/view/61647. Acesso em: 21 abr. 2020.

BRASIL. Constituição Federal de $1988 . \quad$ Disponível em: $<$ http:/wwww.planalto.gov.br/constituição/constituicaocompilado/.htm>. Acesso em: 20 abr. 2020

BRAZILIAN JOURNAL OF LATIN AMERICAN STUDIES. Questão Indígena na América Latina: Direito Constitucional, Novo Constitucionalismo e Organização dos Movimentos Indígenas. Disponível em: http://bit.ly/2PdXkxR. Acesso em: 21 abr. 2020.

CONSELHO INDIGENISTA MISSIONÁRIO. Estado brasileiro é condenado pela Corte Interamericana por violar direitos indígenas. Disponível em: https://cimi.org.br/2018/03/estado-brasileiro-e-condenado-pela-corte-interamericana-porviolar-direitos-indigenas/. Acesso em: 19 abr. 2020.

CONVENÇÃO AMERICANA DE DIREITOS HUMANOS. Organização dos Estados Americanos, 1969.Disponível

em: https://www.cidh.oas.org/basicos/portugues/c.convencao_americana.htm. Acesso em: 20 abr. 2020

CORTE InTERAMERICANA DE DIREITOS HUMANOS. Caso do Povo Indígena Xucuru e seus membros vs. Brasil. Disponível em: https://www.corteidh.or.cr/docs/casos/articulos/seriec_346_por.pdf. Acesso em: 19 abr. 2020.

DESTEFENNI, Marcos. Curso de processo civil: processo de conhecimento convencional e eletrônico. 2. ed. São Paulo: Saraiva, 2009. p. 241.

EL PAÍS. Os Indígenas que Derrotam o Governo Brasileiro na Corte Interamericana. Disponível em: https://brasil.elpais.com/brasil/2018/03/13/politica/1520949894_800892.html. Acesso em: 21 abr. 2020. 
FERREIRA JÚNIOR, Waldir de Jesus Brabo; BENTES, Natália Mascarenhas Simões. O desenvolvimento das normas jus cogens em relação ao reconhecimento do direito à propriedade coletiva dos povos indígenas à luz da sentença do caso Povo Indígena Xucuru e seus membros versus Brasil. Revista da Faculdade de Direito UFPR, Curitiba, PR, Brasil, v. 64, n. 1, p. 9-38, jan./abr. 2019. ISSN 2236-7284. Disponível em: $<$ https://revistas.ufpr.br/direito/article/view/61647>. Acesso em: 04 ago. 2020. DOI:

FUNAI. ÍNDIOS NO BRASIL - TERRAS INDÍGENAS. Disponível em: $<$ http://www.funai.gov.br/index.php/indios-no-brasil/terras-indigenas $>$. Acesso em: 19 abr. 2020

GONÇALVES, Carlos Roberto. Direito Civil Brasileiro: Direito das Coisas. 15. ed. São Paulo: Saraiva Jur, 2020. p. 223-245.

JAYME, Fernando Gonzaga. A RELAÇÃO ENTRE O SISTEMA INTERAMERICANO DE PROTEÇÃO DOS DIREITOS HUMANOS E O DIREITO INTERNO Rev. Fac. Direito UFMG, Belo Horizonte, n. 53,2008. Disponível em: https://www.direito.ufmg.br/revista/index.php/revista/article/viewFile/78/74. Acesso em: 18 abr de 2020

JR., T. S. F. Introdução ao Estudo do Direito: Técnica, Decisão, Dominação. 10. ed. São Paulo: Atlas, 2017. p. 196-197.

MENDES, Gilmar. Jurisdição constitucional. 4. ed. São Paulo: Saraiva, 2004. p. 218.

MINISTÉRIO PÚBLICO FEDERAL. Corte Interamericana de Direitos Humanos condena Brasil por violação de direitos de índios no caso Xucuru. Disponível em: http://www.mpf.mp.br/pgr/noticias-pgr/corte-interamericana-de-direitos-humanos-condenabrasil-por-violacao-de-direitos-de-indios-no-caso-Xucuru. Acesso em: 19 abr. 2020.

NETO, Silvio Beltramelli. Direitos Humanos. 5. ed. Salvador: Juspodivum, 2018. p. 447506.

ORGANIZAÇÃO DOS ESTADOS AMERICANOS. Declaração Americana sobre os Direitos do Povos Indígenas. 2016. Disponível em: http://bit.ly/2UD1eZP. Acesso em : 21 abr. 2020

RAMOS, André de Carvalho. Responsabilidade internacional do Estado por violações aos direitos humanos. R. CEJ, Brasília, n. 29, p. 53-63, abr./jun. 2005. Disponível em http://www2.cjf.jus.br/ojs2/index.php/cej/article/viewFile/663/843. Acesso em: 18 de abr de 2020 .

$\overline{\text { Rio de Janeiro: Renovar, } 2005 .}$

Teoria geral dos direitos humanos na ordem internacional.

Direitos humanos em juízo: comentários aos casos contenciosos e consultivos da Corte Interamericana de Direitos Humanos. São Paulo: Max Limonad, 2001.

RIBEIRO, Lamartine Santos. Direito Consuetudinário Indígena e Positivismo Jurídico: o respeito à alteridade cultural como elemento do Desenvolvimento Local. 2014. Tese (Mestrado em Desenvolvimento Local) - Universidade Católica Dom Bosco. Disponível em: 
$<$ http://site.ucdb.br/public/md-dissertacoes/15461-01-dissertacao-lamartine-cd.pdf $>$. . Acesso em 20 abr.

2020.

SABER ABERTO UNB. O caso do povo Xucuru na Corte Interamericana de Direitos Humanos.

Disponível

em:

http://www.saberaberto.uneb.br/bitstream/20.500.11896/1406/1/TCC\%20BRENDA\%20CAR OLYNE.pdf. Acesso em: 20 abr .2020.

TRIBUNAL REGIONAL FEDERAL DA 5 REGIÃO. Apelação Cível (AC) $\mathbf{N}^{\mathbf{0}} \mathbf{4 1 0 2 1 0} / \mathbf{P E}$ (2004.83.00.011425-4). Apelante: Comunidade Indígena Xucuru de Ororubá. Apelada: Ana Dácia Vieira Mendonça e outros. Disponível em: $<$ http://www4.trf5.jus.br/processo/2004.83.00.011425-4/01> Acesso: 21 abr 2020. 


\title{
CAPÍTULO 9
}

\section{ANÁLISE DO CASO JULGADO PELA CORTE INTERAMERICANA DE DIREITOS HUMANOS: COMPLEXO PENITENCIÁRIO DE PEDRINHAS}

\author{
Guilherme Braga Herrera \\ Guilherme Borsatto \\ Haroldo Freitas Pires De Saboia Filho \\ João Pedro Da Rocha Alonso \\ Letícia Teixeira Pedrosa \\ $\underline{\text { Yolanda Tavaniello De Julio }}$ \\ $\underline{\text { Yago Diniz }}$
}

\section{INTRODUÇÃO}

Não é novidade que o sistema penitenciário brasileiro encontra inúmeras dificuldades na atualidade. Dentre as principais, podemos destacar a superpopulação carcerária, os presídios sem as mínimas condições de higiene, falta de programas de trabalho ou assistência ao apenado, controle dos presídios por facções criminosas, mistura de presos provisórios (sem julgamento) com presos já condenados, a ausência de classificação e separação dos presos por delitos cometidos, além da lentidão na análise dos processos de progressão de regime prisional.

Posto isso, o objeto do presente trabalho é considerado o símbolo da falência do sistema prisional brasileiro. O Complexo Penitenciário de Pedrinhas, hoje Complexo Penitenciário São Luís, possui um histórico de profundas violações de direitos humanos e descaso do Poder Público que mantém há décadas um política criminal que desrespeita o estabelecido nas próprias legislações internas (Lei de Execuções Penais, Constituição Federal, Código Penal) e também nas regras internacionais (Declaração Universal dos Direitos Humanos, Declaração Americana de Direitos e Deveres do Homem e também a Convenção Americana de Direitos Humanos).

Tal Complexo ficou mundialmente conhecido após ter sido palco de uma série de rebeliões entre 2013 e 2014, que deixou mais de 60 mortos.

Diante de tal cenário e a ineficácia de duas resoluções anteriores (datadas de 2014 e 2017) endereçadas ao Brasil pela Corte Internacional de Direitos Humanos (IDH), houve, em 14 de março de 2018, determinação da Corte da Organização dos Estados Americanos acerca da obrigatoriedade da realização de uma reforma no Presídio de Pedrinhas, na qual foi fixado um prazo de três meses para que o Brasil plano de reforma e de redução da superlotação. 


\section{CONTEXTO HISTÓRICO}

Para a melhor compreensão do tema a ser abordado, é necessária uma compreensão ampliada do sistema carcerário brasileiro ao longo da história.

A precariedade e ineficiência do sistema penitenciário do Brasil é reconhecida a anos. Segundo dados do Infopen - principal sistema de informações estatísticas sobre o sistema penitenciário do país - a população carcerária do país é a terceira maior do mundo, com 710 mil presos, perdendo apenas para Estados Unidos e China. O número, já assustador, piora quando se tem em conta que esses 710 mil presos estão distribuídos em espaços que só tem lotação máxima para as mínimas condições de sobrevivência de 423 mil, o que mostra que atualmente o Brasil tem um déficit de 287 mil vagas. A superlotação e a incapacidade de reabilitar os presos, infelizmente, não são as únicas falhas desse sistema. A falta de efetividade nos julgamentos desses detentos, é outro ponto que colabora para a situação atual. O Infopen nos expõe através de estatísticas que $40 \%$ dos detentos são provisórios, ou seja, ainda não foram condenados, podendo haver assim milhares de inocentes que são "esmagados" e inseridos no sistema prisional de modo legitimado pelo Estado. Vale ressaltar que não há qualquer tipo de ressocialização dos presos, já que estes ao entrarem em algum presídio brasileiro se filiam ao tráfico por questão de sobrevivência gerando assim um ciclo vicioso que grande parte dos criminosos não conseguem sair e vão se aprofundando cada vez mais no mundo do crime.

Além disso, de todas as 1507 unidades ativas no país, o complexo penitenciário de Pedrinhas, em São Luís do Maranhão, é um dos grandes representantes da calamidade em que vivem os presos. Desde sua inauguração em 12 de dezembro de 1965 foram registradas diversas rebeliões, sempre envolvendo mortes e muita violência.

\section{DISCURSÃO}

Com base no tema estudado, é possível afirmar que atualmente o Complexo de Pedrinhas encontra-se em uma situação de despreparo para com a sua verdadeira função. Pode-se analisar que os detentos vivem em um verdadeiro "Estado de natureza" descrito pelos filósofos contratualistas, ou seja, durante sua passagem pelo presídio, os detentos "sobrevivem" por um período em que praticamente não há uma sociedade existente, tendo em vista que são tratados como animais, não possuem direitos garantidos, sofrem com a lei do mais forte e com abuso de poder de agentes penitenciários. É válido ressaltar essa analogia 
com o Estado de natureza, pois no caso apresentado, o Estado não interfere para amparar o convívio social dos detentos naquele ambiente hostil. O Conjunto Penitenciário de Pedrinhas em meio à crise penitenciária existente em todo o território nacional (em alguns locais as penitenciárias se encontram mais saturadas que em outros,) foi de certa forma "resgatado" pela Corte Interamericana de Direitos Humanos, já que todos os integrantes que lá cumprem suas penas convivem no dia a dia em um ambiente totalmente caótico, com uma Infraestrutura e condições de detenção nada dignas, com superpopulação do presídio e celas. Ademais, os indivíduos que ali vivem, sofrem com a omissão do Estado em questões de saúde como atendimentos médicos, problemas urgentes, doenças, cuidados básicos e higiene, sendo todos os fatores considerados necessários para um bem-estar; dignidade do sujeito. O complexo penitenciário falha também no quesito de segurança, violência e mortes causadas por guerra entre facções rivais, tortura e violência dos próprios agentes representantes do Estados, os quais deveriam proteger e não lesar a integridade física.

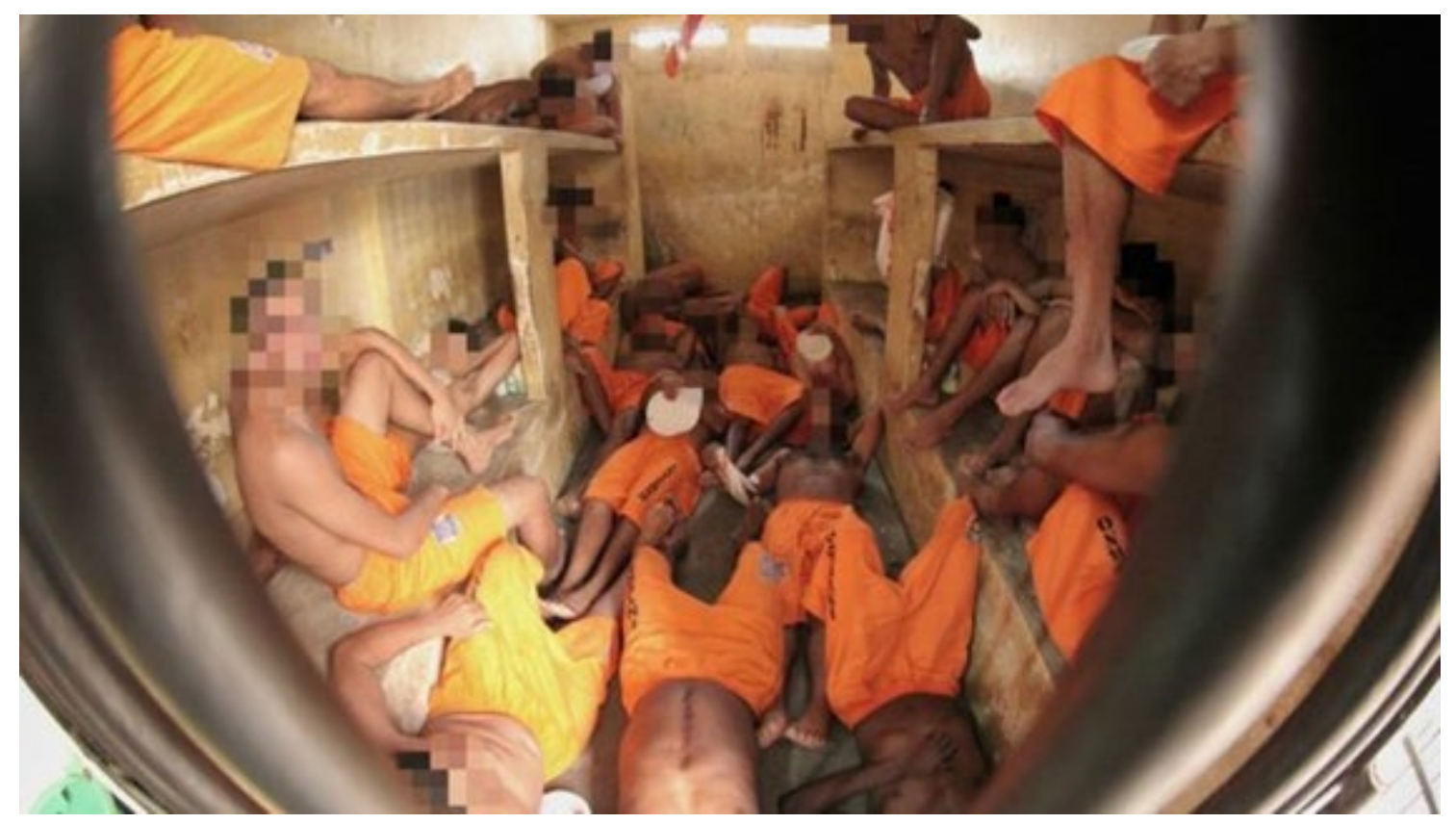

Fonte: BBC BRASIL em: https://www.bbc.com/portuguese/brasil-37581856

Como exposto no texto acima, a foto de uma das celas exemplifica o problema estrutural que vive atualmente o complexo Penitenciário de Pedrinhas em São Luís. A superlotação das celas é um problema recorrente no presídio; uma cela com capacidade para 8 pessoas é ocupada por mais de 15 . Com o relato de alguns detentos, muitos dizem passar dias sem conseguir dormir por causa do calor, da umidade e da falta de ventilação. Alguns presidiários relataram que usam as próprias camisas para enxugar vazamentos que inundam o 
piso. As cenas descritas apenas confirmam uma extrema situação de insalubridade, e de que submeter os detentos a essas condições equivale a tortura.

\title{
FATOS
}

A Penitenciária Agrícola de Pedrinhas foi construída em 1965, em plena ditadura militar, pelo então Governador do Maranhão, Newton de Barros Belo, na margem da BR-135, Km 13 com área de 122 hectares em bairro com igual nome. O presídio já foi erguido de forma precária, improvisada e sem nenhuma condição de funcionamento adequado.

De acordo com o relatório feito pelo Sindicato dos Servidores do Sistema Penitenciário do Estado do Maranhão - SINDSPEM/MA, citado por Freitas e Piedade (2016):

\begin{abstract}
A Penitenciária de Pedrinhas fincou-se num terreno acidentado, de natureza árida, e quase impróprio para a agricultura. No ano de 1965, durante o Governo Newton de Barros Belo foi construída a Penitenciária Agrícola de Pedrinhas, com capacidade para alojar 120 (cento e vinte) detentos. A cada dia aumenta em população o que faz com que se multipliquem as dificuldades de relações sociais e, consequentemente, eleva-se a taxa da criminalidade. $O$ fato de só se ter uma concentração de presídio para o Estado do Maranhão corrobora a superlotação das Unidades da Penitenciária de Pedrinhas.
\end{abstract}

Durante a "era Sarney" (1985-1990) o presídio sofreu reformas visando seu concerto e ampliação, as quais mostraram ser verdadeiros "remendos" uma vez feitas em um prédio base sem infraestrutura adequada, e ao longo dos anos se transformou em Complexo Penitenciário de Pedrinhas formado por 8 unidades.

Acumulou críticas em comissões parlamentares de inquérito realizadas na Câmara dos Deputados (2009 e 2015), recomendações de interdição pelo Conselho Nacional de Justiça, além de uma série de mortes por decapitação, torturas e estupros, se consolidando como símbolo internacional de violência na prisão.

Dentro do presídio, os detentos eram separados de acordo com suas facções, sendo três as principais: "anjos da morte" (composta por membros do interior), "primeiro comando do Maranhão" (composta por membros da capital) e "os bondes do 40" (composta por membros da capital e eleita como a facção mais violenta). Além de que se encontrava superlotado, não havia agentes penitenciários suficientes para o número de presos e isso contribuiu para a destituição do poder estatal dentro do presídio e à posse dos líderes de facção.

Uma série de rebeliões que ocorreram entre novembro e dezembro de 2013 levou a Sociedade Maranhense de direitos humanos (SMDH) e a OAB-MA (Ordem dos Advogados do Brasil) a acionarem a Comissão Interamericana de direitos humanos (CIDH), órgão que é vinculado à OEA (Organização dos Estados Americanos). A comissão aprovou a resolução e 
outorgou medida cautelar obrigando o país a agir para evitar novas mortes, reduzir a superlotação do presídio e investigar os fatos denunciados, sob risco de uma condenação internacional.

Diante da falta de melhora nas condições de encarceramento em Pedrinhas, a CIDH remeteu o caso à Corte Interamericana de Direitos Humanos, a qual expediu medida provisória obrigando o estado brasileiro a adotar as ações para proteger a integridade física e a vida de todos os encarcerados e funcionários.

Em 17 de fevereiro de 2017, a Corte emitiu resolução solicitando informações sobre o sistema penitenciário brasileiro e o Complexo Penitenciário de Pedrinhas.

Foram recebidos escritos do estado e dos representantes dos beneficiários entre 2015 e 2018. A partir desses, também foram apresentados relatórios do Estado sobre o cumprimento da medida provisória e por parte dos representantes foram apresentadas observações a respeito dos relatórios estatais.

Em 14 de março de 2018 foi emitida resolução pela Corte onde solicitou novamente a adoção das medidas necessárias para proteger eficazmente a vida e integridade pessoal de todas as pessoas privadas de liberdade no Complexo de Pedrinhas, assim como o envio de informações sobre as medidas adotadas para o cumprimento das medidas provisórias ordenadas.

Foi apresentado então um relatório independente do Ministério Público do Maranhão como resposta a um ponto resolutivo da resolução anterior.

\section{INFRAESTRUTURA E CONDIÇÕES DE DETENÇÃO}

A situação carcerária é uma das questões mais complexas da realidade social brasileira. No Brasil, têm sido constantes as notícias veiculadas nos meios de comunicação sobre a precariedade do sistema prisional brasileiro e as violações de direitos humanos que ocorrem cotidianamente no interior dos presídios; um triste acontecimento que tem se intensificado nos últimos tempos.

A superlotação dos presídios, fato que se enquadra dentro das condições do dia a dia de um detento e da infraestrutura de um presídio, tem sido apontada como uma das principais causas de violação de diversos direitos humanos consagrados em vários instrumentos internacionais, muitos dos quais o Brasil é parte; como a Declaração Universal dos Direitos Humanos de 1948; a Declaração Americana dos Direitos e Deveres do Homem de 1948; as 
Regras Mínimas para o Tratamento dos Reclusos de 1955; o Pacto Internacional sobre Direitos Civis e Políticos e o Pacto Internacional sobre Direitos Econômicos, Sociais e Culturais ambos de 1966, a Convenção Americana Sobre Direitos Humanos de 1969, também conhecida como Pacto de São José da Costa Rica, e a Convenção Contra a Tortura e Outros Tratamentos ou Penas Cruéis, Desumanos ou Degradantes de 1984. É válido, com base no Direito Penal, ressaltar que a pena de prisão levada a efeito pelo ente estatal tenha como um de seus principais efeitos a privação da liberdade dos indivíduos condenados no âmbito de um devido processo legal, contudo, o Estado é falho ao privar o preso de uma série de outros direitos e da dignidade humana que lhe é inerente e que deve acompanhá-lo mesmo dentro dos presídios.

A Lei de Execução Penal $n^{\circ} 7.210 / 1984$ garante ao preso e ao internado a devida assistência e outras garantias legais. No entanto, ao contrário do que estabelece a lei, os presídios atualmente proporcionam um ambiente degradante e desumano ao preso, tendo em vista, a superlotação, a ausência de assistência médica, a precariedade na alimentação e a falta de higiene que desencadeiam diversas doenças. O declínio do sistema prisional brasileiro atinge não somente os apenados, mas também as pessoas que estão em contato com essa realidade carcerária de forma direta ou indireta. Diante do que foi citado anteriormente, o sistema prisional, por consequência de sua realidade, acaba acarretando a reincidência dos presos, porém, se os mesmos fossem tratados com dignidade, ambos iriam se reintegrar de forma adequada na sociedade com base na garantia constitucional do princípio da dignidade da pessoa humana, atingindo assim os objetivos do sistema prisional (MACHADO; GUIMARÃES; 2014, p. 567).

A precariedade encontrada ao analisar a penitenciária de pedrinhas, especialmente representada pela superlotação, que por sua vez acaba por constituir um mecanismo de potencialização de múltiplas violações de direitos humanos, revela também a falha e a incapacidade do Estado brasileiro em cumprir um dos principais objetivos da sanção que é a promoção da ressocialização dos indivíduos e a sua reinserção para uma vida plena em sociedade. A superlotação acaba por alojar indivíduos de facções rivais em uma mesma cela de poucos metros quadrados e resulta na criação de brigas e até mesmo mortes, as quais seriam evitáveis se o sistema carcerário estivesse preparado e possuísse a infraestrutura necessária, tanto no presídio de pedrinhas, como na grande maioria de presídios existentes no país. A conclusão é a mesma, no Brasil há uma insuficiência e ineficiência estrutural para acomodar um elevadíssimo número de reclusos com dignidade. 


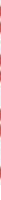

É por essa falta de despreparo do Estado que a Corte IDH requereu a tomada de medidas provisórias ao Brasil (no Complexo de Pedrinhas) mediante algumas recomendações e visando a cessação de violações de direitos humanos, a erradicação de diversas situações de risco e, sobretudo, a proteção da vida e da integridade pessoal, psíquica e moral desses detentos.

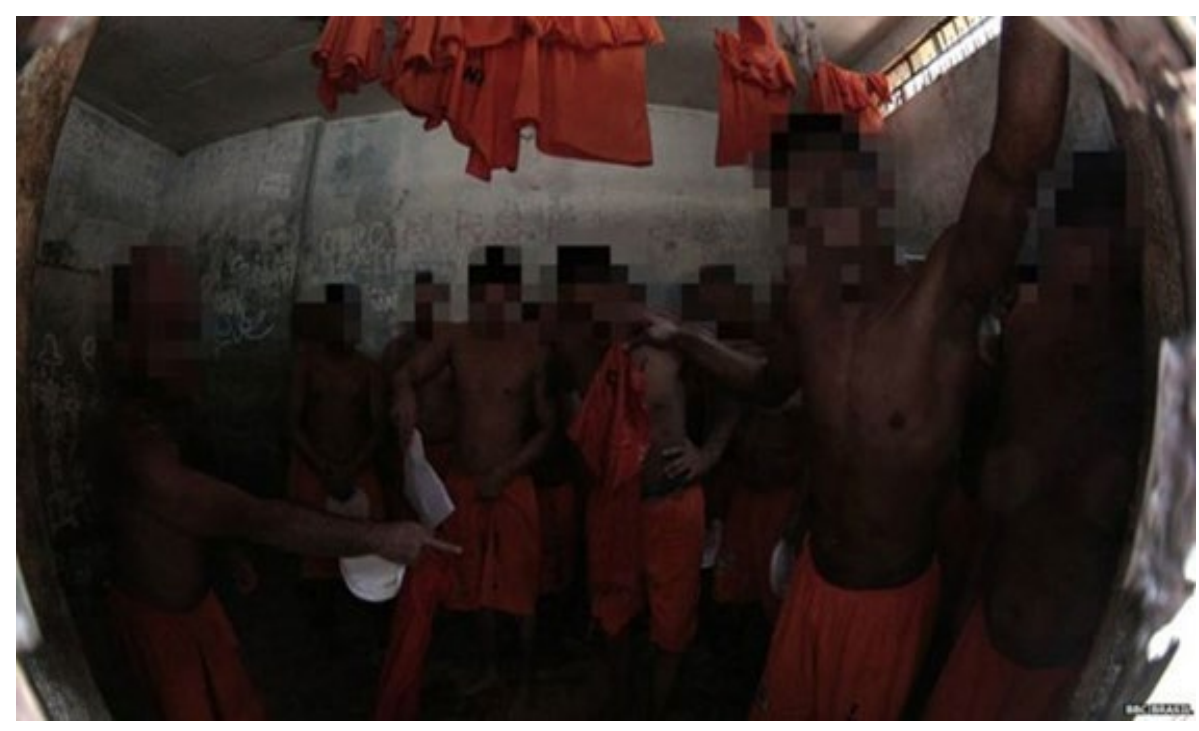

Fonte: BBC BRASIL em: https://www.bbc.com/portuguese/brasil-37581856

(Na imagem acima, presos utilizam suas próprias camisas para secar o chão molhado, tendo em vista que muitos dormem no chão, pois não há leitos para todos na cela.)

A superlotação prisional no Brasil é diversa do artigo 85 da Lei de Execução Penal, o qual prevê, "O estabelecimento penal deverá ter lotação compatível com a sua estrutura e finalidade" (MACHADO; GUIMARÃES, 2014, p. 574).

Um dos episódios que mais demonstram esse despreparo do Estado para com o presídio de pedrinhas, são as rebelião que ocorrem no presídio, como a que aconteceu em 2013, envolvendo as duas maiores facções criminosas de São Luís levou ao caos, o confronto entre os grupos rivais da Casa de Detenção (Cadet) de Pedrinhas, que deixou pelo menos 9 mortos e 20 feridos, dentre eles, Fábio Silva Lima tinha 29 anos quando foi atingido por um tiro na cabeça em meio a uma das rebeliões no Complexo Penitenciário São Luís em outubro de 2013. Cumprindo pena por tráfico de drogas, estava prestes a ir para o regime semiaberto no qual iria trabalhar como pedreiro.

Segundo Jair Aparecido Ribeiro, citado por Machado e Guimarães (2014, p. 572):

O Estado deslocou seu foco, para uma simples manutenção da ordem, esquecendo-se dos princípios orientadores, seus fundamentos, isto leva a mudança de visão acerca do preso, pois quando o próprio Estado esquece que o indivíduo preso é um cidadão 
que faz parte do mesmo, isto se reflete em toda sociedade, a qual passa a tratar o preso, mesmo depois de ter cumprido a pena, como não mais sendo este um cidadão.

As pessoas presas no Complexo de Pedrinhas e no Brasil em geral, não são destituídas apenas do seu direito à liberdade, mas também têm violadas a sua dignidade e uma série de outros direitos (por exemplo, o direito à vida, à integridade física e psicológica, de não ser submetido a penas ou tratamentos desumanos ou degradantes etc.) que deveriam ser protegidos e garantidos pelo Estado dentro das prisões. Tudo em razão da precariedade do sistema prisional do país.

Além disso, Salla (2006, p. 288) complementa que:

as rebeliões no Brasil têm sido provocadas, muitas vezes, a partir de disputas entre grupos organizados que usam a rebelião como instrumento de desordem para acertos de contas, para matar lideranças rivais, para vingar mortes de companheiros em outras prisões e para repactuar as relações entre os grupos criminosos.

Esse entendimento reforça ainda mais a noção de como o crime organizado domina as situações nos presídios brasileiro, e anula qualquer tipo de ação estatal que vise ressocializar o preso para um futuro promissor fora da cadeia. O que opera na verdade é um sistema opressor do crime em que ou o bandido entra para alguma facção e se envolve completamente no mundo crime ou este é ameaçado de morte assim como sua família.

\section{ATENDIMENTO DE SAÚDE}

Saúde é direito social fundamental implementado na Constituição Federal de 1988, previsto em seu Art. $6^{\circ}$ e em seu Art. 196:

Art. $6^{\circ}$. São direitos sociais a educação, a saúde, o trabalho, a moradia, o lazer, a segurança, a previdência social, a proteção à maternidade e à infância, a assistência aos desamparados, na forma desta Constituição.

Art. 196. A saúde é direito de todos e dever do Estado, garantido mediante políticas sociais e econômicas que visem à redução do risco de doença e de outros agravos e ao acesso universal e igualitário às ações e serviços para sua promoção, proteção e recuperação.

Além de ser garantido também na Lei $\mathrm{N}^{\circ} 8080$ de 19 de setembro de 1990, denominada Lei Orgânica da Saúde, que diz "a saúde é um direito do cidadão e dever do Estado, e deve ser garantida mediante a oferta de políticas sociais econômicas”. O artigo 197 da nossa constituição prevê os mecanismos de funcionamento da rede regionalizada e hierarquizada que constituem o Sistema Único de Saúde (SUS). O sistema de saúde universal e gratuito surgiu como a principal política pública da área da saúde em face da garantia de direitos fundamentais, principalmente os de segunda geração (conhecidos como direitos sociais). 


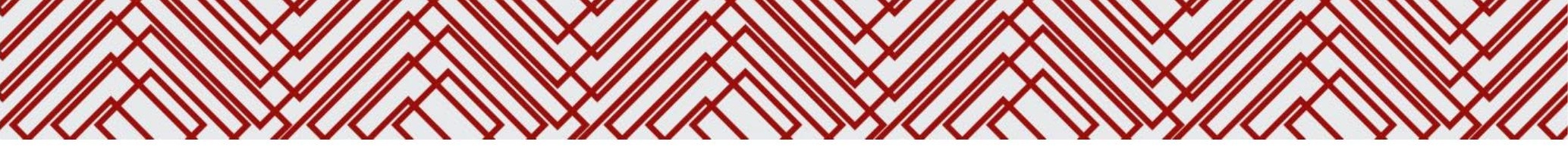

No sistema prisional brasileiro tal direito constitucional não é oferecido de forma eficaz, de modo que muitos encarcerados acabam morrendo por problemas de saúde tratáveis, como diarreia e tuberculose. A falta de saneamento básico, de equipe profissional qualificada e a insalubridade nos presídios com a pouca circulação de ar e a escassez de produtos de higiene, roupas e colchões contribuem para essa realidade.

No complexo penitenciário de Pedrinhas, a situação higiênica e médica era insustentável, internos com bolsa de colostomia precisam conviver com ratos e baratas, sem kits de higiene pessoal e com feridas infectadas sem tratamento, a propagação de doenças de pele é grande dentro dos blocos. No antigo Centro de Detenção Provisória conviviam mais de 500 internos com apenas um enfermeiro em meio período.

A Corte Interamericana de Direitos Humanos constatou que as condições no Complexo de Pedrinhas continuam insalubres, principalmente quanto à falta de profissionais de saúde e das condições nas celas, com a infestação de animais e sem acesso dos detentos a produtos básicos de higiene pessoal. A Corte afirmou que devem ser cumpridas as Regras de Mandela, que são regras mínimas para o tratamento de reclusos, estas regras implicam na garantia por parte do Estado do acesso ao aquecimento e ventilação, acesso ao ar fresco e garantia de luz artificial, instalações sanitárias, banho e chuveiro adequados e limpos, acesso a recursos de higiene indispensáveis, vestuário e roupa de cama individual, boa alimentação, serviços médicos, tratamento de doenças contagiosas e tratamento especial e supervisão de psiquiatra para detentos com transtorno mentais. Além disso, a Corte também constatou que o protocolo de atenção médica do Complexo seja modificado visando um melhor atendimento aos necessitados.

\section{MORTE E VIOLÊNCIA}

A fala da Senadora Ana Rita pelo estado do Maranhão, citado por Carvalho e Batista (2015, p. 3) explica como a crise do sistema carcerário no Maranhão que foi intensificada a partir de 2013 é comandada pelas facções tanto dentro quanto fora do presídio:

Os efeitos dessa crise realmente não se restringiram aos muros da unidade prisional, escutas comprovam que essas faç̧ões criminosas mantenedoras do controle interno do presídio, deram as ordens de ataques no Maranhão, desencadeando pânico na população. De dentro do presídio os comandos foram dados para atentados contra a polícia, ônibus serem incendiados e em um dos casos, uma criança foi morta pelos criminosos que atearam fogo em seu corpo. $\mathrm{O}$ terror, a insegurança e a revolta tomaram a sociedade local, houve manifestações populares e o horror foi amplamente disseminado através de redes sociais. 


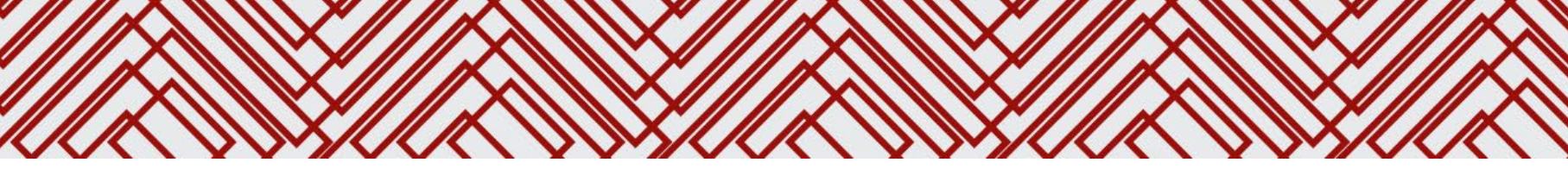

Entre 2013 e 2014 foram cerca de 70 mortos oficiais que ocorrem no Complexo de Pedrinhas durante as rebeliões. Toda situação de insalubridade e desumanidade já foi enunciada e reforçada acima, cada dizer algumas das medidas tomadas pela Corte IDH para conter as mortes e fiscalizar as causas das que houverem.

A Corte, em questão de prioridade, determinou que o governo brasileiro produza um relatório com diagnósticos completos sobre a reestruturação para diminuir a superlotação em face da diminuição de conflitos e consequentemente diminuição do número de mortes e momentos de violência entre os presos. Além disso, a Corte IDH deixou claro na resolução a falta de acesso de um relatório explicativo sobre as mortes que ocorreram dentro dos presídios. Fica óbvio que o conhecimento dessas mortes é imprescindível para o órgão internacional, já que, com um informativo sobre as doenças mais contagiosas que mais matam dentro dos presídios, por exemplo, é possível criar mais facilmente um plano de combate mais consistente contra essa doença. Essa forma se repete, nos casos de violência, pois se o Estado souber os motivos de rebeliões e briga dentro dos presídios torna-se menos difícil elaborar um plano para conter e evitar conflitos.

Ademais, os crimes cometidos durante o período em que ocorreram as rebeliões no presídio, se estenderam pelas ruas da capital maranhense. Em 2014, o feirante Domingos Pereira Coelho foi executado em frente a barraca em que vendia suas mercadorias. $\mathrm{O}$ comerciante era conhecido na cidade como "Laranjeiro", e era pai de um dos presidiários que foi decapitado em uma rebelião no presídio de Pedrinhas. A polícia suspeita que o crime tenha sido cometido pelo fato do comerciante ter apresentado denúncias contra os assassinos do seu filho.

Outrossim, o Ministério Público denunciou uma série de barbaridades cometidas no local. Segundo relatos, além de assassinato e tortura, houve um episódio de canibalismo, onde um dos presos foi executado e teve seu fígado comido por um dos acusados do crime.

\section{TEORIA DO ESTADO DE COISAS INCONSTITUCIONAL (ECI)}

Essa teoria foi desenvolvida pela Corte Constitucional da Colômbia para servir como instrumento de reconhecimento em massa de violação de direitos fundamentais. Além da omissão do Estado nesses casos para cumprir o que é previsto na Convenção Americana dos Direitos Humanos, foi utilizada diversas vezes para expor violações de direito à vida, integridade física, mental e psicológica contra detentos em diversos sistemas prisionais. 


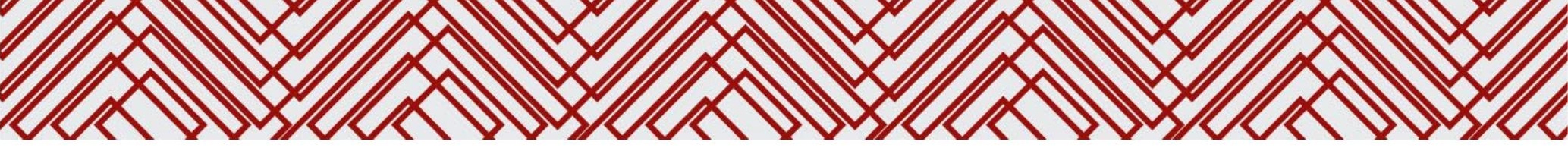

No Brasil, as violações a todos estabelecimentos carcerários, não só os presídios. Desse modo, tanto presos como menores infratores e deficientes estão em situação de vulnerabilidade e diretamente sofrem com violações de seus direitos básicos de dignidade. A medida provisória proferida pela Corte IDH no caso do Complexo de Pedrinhas foi a resposta que o Sistema Interamericano conseguiu dar às diversas mortes, agressões e momentos de conflito que houveram durante o período de rebeliões no estado do Maranhão.

Conforme exposto por Guimarães (2017, p. 88):

A ADPF n. 347, ajuizada pelo PSOL, objetiva o reconhecimento pelo STF do estado de coisas inconstitucional do sistema penitenciário brasileiro bem como a determinação de adoção de medidas tendentes a sanar as gravíssimas lesões a preceitos fundamentais da Constituição, decorrentes de condutas comissivas e omissivas dos poderes públicos do Estado no tratamento da questão prisional do País.

Infelizmente, nenhuma reparação jurídica internacional ou nacional será condizente com toda dor, sofrimento, desespero e tristeza vivido por todos os sujeitos durante esse momento sangrento e terrível do sistema prisional brasileiro. A demora para que se esgote todo a possibilidade do ordenamento jurídico interno e que só após isso o caso consiga chegar ao SIDH, especificamente a Corte IDH, faz com que a omissão do Estado em questão se prolongue assim como as violações graves contra os direitos humanos, que acabam se expandindo no caso determinando e legitimando outras condutas semelhantes. A problemática dessa demora é ainda maior quando se trata de um caso urgente e eminente, como o de Pedrinhas. Visto que, cada dia, cada hora, cada minuto importa quando se trata em salvar vidas e defender a integridade de cada indivíduo.

SENTENÇA E REPARAÇÃO

Em especial no presídio de pedrinhas, foi possível a identificação de diversas violações aos direitos humanos, entre elas a presença de celas escuras, mal ventiladas e úmidas, baixa qualidade de alimentação, elevado número de rebelião, atendimento médico, odontológico e medicamentoso quase inexistente, corrupção, ausência de atividades ocupacionais e educacionais.

A violência dentro do presídio, que se tornou incontrolável pelo governo, gerou a perda de muitas vidas humanas, que por inércia da administração e controle do governo, entrou em um verdadeiro colapso.

No dia 14 de novembro de 2014, a Corte determinou que o Brasil adotasse, de imediato, todas as medidas necessárias para proteção à vida e a integridade pessoal das 
pessoas privadas de liberdade no Complexo penitenciário de Pedrinhas, com o dever de reduzir a superlotação, superar as causas da violência, garantir condições de segurança e respeito à vida, sendo apresentados relatórios do Estado para a Corte.

O Tribunal considerou necessário que o Estado elabore um diagnóstico técnico atualizado da situação de infraestrutura, superpopulação e superlotação do Complexo Penitenciário de Pedrinhas. Além disso, considerou-se necessário também que o estado elabore um plano de contingência para a reforma estrutural e de redução da superpopulação na penitenciária. Do mesmo modo, determinou a separação dos detentos segundo previsto na legislação brasileira, com intuito de cessação da violência.

Com a existência de inúmeras barreiras a serem destruídas, o tribunal determinou os problemas a serem sanados com maiores urgências, que são: $O$ acesso a água, alimentação adequada e higiene pessoal e diminuição da superlotação, além do fornecimento de colchões e roupas, sendo que esta corte salienta que o Estado não pode alegar dificuldades financeiras para justificar o descumprimento de suas obrigações internacionais.

No quesito da saúde dos detentos, a corte considera que o Brasil deve informar sobre as medidas adotadas para o atendimento geral de saúde dos internos e de prevenção e tratamento de doenças infecto contagiosas, em especial a tuberculose, viroses e doenças de pele.

Já em relação a violência constante, com grave ameaça a dignidade da pessoa humana, a Corte salientou que a diminuição da superlotação é um fator primordial para a garantia dos direitos humanos dentro das celas, sendo papel do Estado proteger os detentos. Por fim, o tribunal considera que a situação do presídio não atende às normas universais, regionais e nacionais que estabelecem determinados indicadores mínimos de condições de habitação.

A Corte Interamericana de Direitos Humanos solicitou que o Estado cumpra imediatamente as medidas para proteção de todas as pessoas privadas de liberdade no Complexo Penitenciário de Pedrinhas, bem como os funcionários, agentes públicos e visitantes. Para garantia de cumprimento, o Estado deverá enviar diagnóstico técnico e plano de contingência, além de informar a Corte Interamericana de Direitos Humanos, a cada 3 meses sobre a implementação das medidas provisórias adotadas em conformidade com essa decisão, além de relatórios independentes com dados de todas as mortes, sendo elas naturais ou frutos de violência, ocorridas desde janeiro de 2015. 


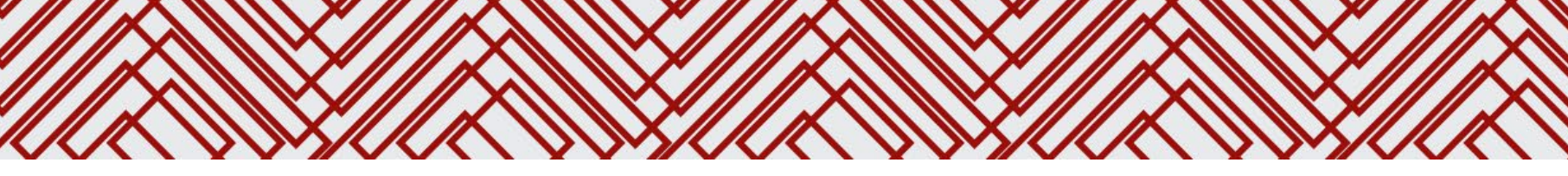

Após diversas decisões feitas pela Corte interamericana de Direitos Humanos, o Estado brasileiros, por diversas vezes, tiveram de pagar indenização por danos morais, aos presos que se encontravam nas condições insalubres citadas. No entanto, as denúncias com o passar dos anos não diminuíram e continuam a denegrir a situação carcerária no Maranhão.

É importante ressaltar que esse problema carcerário dentro do presídio de pedrinhas, na realidade, é somente uma das diversas indicações de que o Brasil, têm realmente um problema estrutural com os seus presídios como um todo, rebeliões, mortes e todo o cenário das facções são situações recorrentes dentro de todo território brasileiro. Assim fica claro que apesar da Corte Interamericana de Direitos Humanos ter se referido ao presídio como um local que precisa de muita atenção, este não é o único problema do sistema prisional no Brasil. Alguns desses problemas podem ser vistos em todo o território nacional, como a superlotação, a precariedade da saúde e principalmente a má administração das instalações. Portanto é de suma importância neste trabalho destacar que os problemas crônicos que estão sendo citados pelo presídio de pedrinhas, na realidade são um empecilho para toda a administração pública do Brasil.

De acordo com o Recurso Extraordinário 580.252 publicado pelo STF, no dia 16 de setembro de 2012, tendo como relator o ministro Gilmar Mendes em setembro de 2012, fica explícito o dever do Estado de indenização aos presos de qualquer sistema prisional que sofreram algum tipo de dano, o ocasiona a responsabilidade civil do Estado. Essa decisão reforça o entendimento da suprema corte brasileira em procurar defender cada vez mais a dignidade humanas dos presos e presas, no intuito de diminuir a discrepância de toda violência e desumanidade causada pelo colapso de nosso atual sistema prisional.

\section{CONCLUSÃO}

Ante o exposto, percebe-se que os presidiários que habitam o sítio da penitenciária vivem em uma situação aquém da sociedade, uma situação inadmissível no contexto dos direitos humanos, tendo em vista que dentre os objetivos almejados pela medida de reclusão, a ressocialização do detento deveria importar. Não é o que acontece nesse caso, pois após todas as exposições fáticas, depreende-se que esta instituição carcerária ataca mais a ordem social do que a protege.

Destaca-se aqui a questão do sistema carcerário brasileiro como um todo, sendo o Presídio de Pedrinhas apenas mais um triste exemplo da maneira que lidamos com aqueles que precisam de respaldo para voltarem a ser partes funcionais da sociedade. $\mathrm{O}$ 
operacionismo distópico do sistema carcerário vigente segue tirando vidas de todas as maneiras, seja por falta de saúde, de alimentação, ou simplesmente pela violência que tende a ser o resultado de todo esse processo. A atuação da Corte IDH, mesmo que desejada, não poderá sanar essa anemia social que se alastrou por todo o país, visto que o lugar de ação recai sob o Estado Brasileiro.

Pois bem, a conclusão mais sensata atinge o tema de uma necessária reforma do sistema carcerário como um todo, da infraestrutura que abriga os presos, até o modo como a administração os tratam, partindo de um ponto de vista que considera a realocação de verbas públicas para a melhoria da condição dos presos um investimento, e não um simples gasto, visando sempre a ressocialização do preso para que ele retorne pronto para contribuir no âmbito comunitário. Até que esse dia chegue, trabalhos como este precisarão ser publicados com o intuito de trazer luz para um tema tão sensível e atemporal, que é o tratamento carcerário no Brasil.

\section{REFERÊNCIAS}

BRASIL. Constituição (1988). Constituição da República Federativa do Brasil. Brasília:
DF: $\quad$ Senado em:<http:/wwww.planalto.gov.br/constituição/constituicaocompilado/.htm>. Acesso em: 13 mai. 2020.

BRASIL. Lei $\mathbf{n}^{\circ} \mathbf{7 . 2 1 0}$ de 11 de julho de 1984. Institui a Lei de Execução Penal. Diário Oficial da União, Brasília, DF, 1984.

BRASIL. Superior Tribunal Federal. Recurso Extraordinário no 580.252. Relator: Ministro Gilmar Mendes. Brasília, MS, 24 de agosto de 2001. Mato Grosso do Sul. Disponível em: https://www.conjur.com.br/dl/estado-indenizar-preso-situacao.pdf. Acesso em: 25 jul. 2020.

CARVALHO, Gleick Sena de Jesus; BATISTA, Hellayne Chistine Ferraz. A MASMORRA DO SÉC.XXI - AS VIOLAÇÕES DOS DIREITOS HUMANOS NO COMPLEXO PENITENCIÁRIO DE PEDRINHAS E AS MEDIDAS TOMADAS PELO GOVERNO DO ESTADO DO MARANHÃO. VII Jornada Internacional Políticas Públicas, São Luís, p. 18, 2016. Semestral. Disponível em: http://www.joinpp.ufma.br/jornadas/joinpp2015/pdfs/eixo7/a-masmorra-do-secxxi---asviolacoes-dos-direitos-humanos-no-complexo-penitenciario-de-pedrinhas-e-as-medidastomadas-pelo-governo-do-estado-do-maranhao.pdf. Acesso em: 02 ago. 2020

CONECTAS. CORTE IDH DETERMINA REFORMA DE PRESÍDIO DE PEDRINHAS. Disponível em: https://www.conectas.org/noticias/corte-interamericanadetermina-que-governo-brasileiro-reforme-prisoes-de-pedrinhas-e-faca-levantamento-sobremortes-ocorridas-desde-2015. Acesso em: 19 mai. 2020.

CORTE INTERAMERICANA DE DIREITOS HUMANOS. Presídio de Predinhas. Disponível em: http://www.corteidh.or.cr/docs/medidas/pedrinhas_se_02_por.pdf. Acesso em: 12 mai. 2020. 



\section{PREFÁCIO}

\section{Uma publicação necessária para o incentivo à pesquisa e para 0 aprofundamento do ensino}

Luís Renato Vedovato ${ }^{18}$

Com muita felicidade que recebi o convite da Professora Carolina Piccolotto Galib, da Estudante Giovanna Baldan e do Estudante Pedro A. C. Simbera, para apresentar o trabalho que resultou na presente obra "PRÁTICA JURÍDICA EM DIREITOS HUMANOS: ESTUDOS DE CASOS", o que para mim é uma grande honra e um enorme privilégio.

Por falar nesse ponto, um privilégio que eu ainda não tive é o de ser aluno da Profa. Carolina, porém, ela ensina pelos seus frutos e, por esse livro, pode-se ver que muito se aprende com ela e, como a obra aqui prefaciada demonstra, mais ainda se cria com seu incentivo constante e seu brilhantismo cotidiano.

Também destacam-se jovens brilhantes estudantes na organização, que é de responsabilidade de Giovanna e Pedro, em conjunto com a Professora. Tais estudantes são de dedicação ímpar e inteligência destacada, não só pelo trabalho ora apresentado, mas também por todo o histórico de dedicação e pesquisa que possuem na Universidade, nos corredores da PUCC, na sua Faculdade de Direito.

O livro que se traz à luz é por todos os aspectos que se veja um grande acontecimento, por ter nascido do trabalho da aula, por ter sido resultado de pesquisa, por ter sido iniciativa de Professora e estudantes, por ser inovadora ao analisar os casos e, mais do que tudo, por ser muito mais do que se espera de uma turma de universitárias e universitários. É um claro indicativo de que não há trabalho grande demais para quem está nessa empreitada.

Exatamente por isso, além dos elogios, devo dizer que esse trabalho marca a Faculdade de Direito, marca estudantes, marca o curso e marca a Professora, tudo para claramente trazer a tona o potencial do corpo discente e do corpo docente da nossa universidade.

\footnotetext{
${ }^{18}$ Luís Renato Vedovato é advogado, doutor em Direito Internacional pela Faculdade de Direito da Universidade de São Paulo, Professor Doutor da PUC de Campinas e da Universidade Estadual de Campinas (UNICAMP). Pesquisador da FAPESP.
} 
Com 45 estudantes construindo as bases da obra aprofundada em 10 capítulos bem estruturados e desenvolvidos, há detalhamento de temas e casos relativos a direitos humanos de uma forma ao mesmo tempo acessível e bastante técnica.

O primeiro capítulo SOBRE A IMPORTÂNCIA DO ENSINO DE PRÁTICA DE DIREITOS HUMANOS vem para destacar com precisão o quanto é relevante a aplicação prática e a análise do direito a partir de casos, dando voz a quem vê a análise de casos como fundamental para construção do conhecimento científico.

As cotas raciais, a proteção das pessoas com deficiência, o caso Ellwanger, a estrutura do Sistema Interamericano, a Lei Maria da Penha, as condenações sofridas pelo Brasil na Corte Interamericana, o Povo Indígena Xucuru e, por fim, o complexo penitenciário de Pedrinhas são todos tratados com brilhantismo e profundidade na presente obra, que avança e supera as expectativas de leitores.

De fato, o trabalho é de grande importância, não apenas por seu conteúdo, que é bem estruturado e com reflexões e relatos de relevância indiscutível, mas também por ser um incentivo e um chamado para quem busca transformar as pesquisas em guias para as próximas gerações de estudantes.

Nesse sentido, resta-me agradecer a generosidade de me convidarem para escrever essas poucas linhas e também por trazer a lume tão relevante trabalho. O que fica de tudo isso é a certeza que esse será um livro que ultrapassará as ambições de quem o imaginou. E se eu pudesse dizer uma última frase, diria, aproveitem a leitura, ela é essencial.

Campinas, 28 de setembro de 2020.

Luís Renato Vedovato 


\section{SOBRE OS ORGANIZADORES}

\section{Carolina Piccolotto Galib}

Doutoranda em Filosofia do Direito (PUC-SP). Mestra em Direito (UNIMEP). Especialista em Direito Constitucional Aplicado (UNICAMP). Professora de Direito Internacional e Prática Jurídica em Direitos Humanos da PUC-Campinas.

\section{Giovanna Baldan}

Estudante do 7 semestre do curso de Direito da Pontifícia Universidade Católica de Campinas - PUCCAMP.

\section{Pedro Augusto de Castro Simbera}

Graduando do curso de Direito na Pontifícia Universidade Católica de Campinas (PUCC); Aluno pesquisador de Iniciação Científica com bolsa CNPq, na vigência de 2020 - 2021; Membro do grupo CNPq "Direito num mundo globalizado"; Membro do Núcleo de Ensino Clínico em Direitos Humanos da PUCC (NEC-DH) e Monitor da disciplina: Direitos Humanos I e II. 
www.editorapublicar.com.br contato@editorapublicar.com.br @epublicar facebook.com.br/epublicar

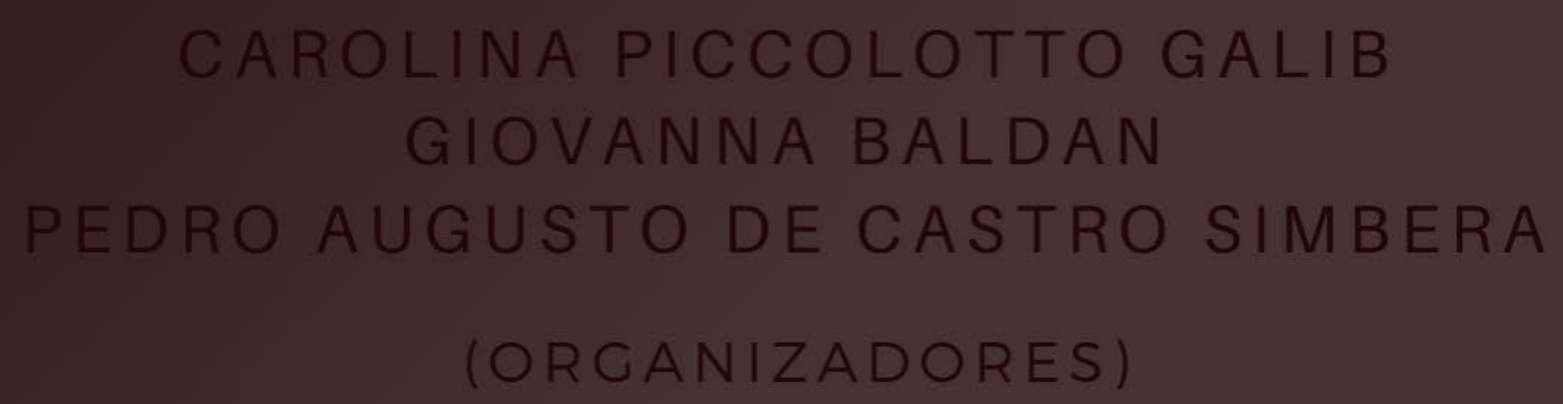

PRÁTICA JURÍDICA EM DIREITOS HUMANOS: ESTUDOS DE CASO, 
www.editorapublicar.com.br contato@editorapublicar.com.br @epublicar facebook.com.br/epublicar

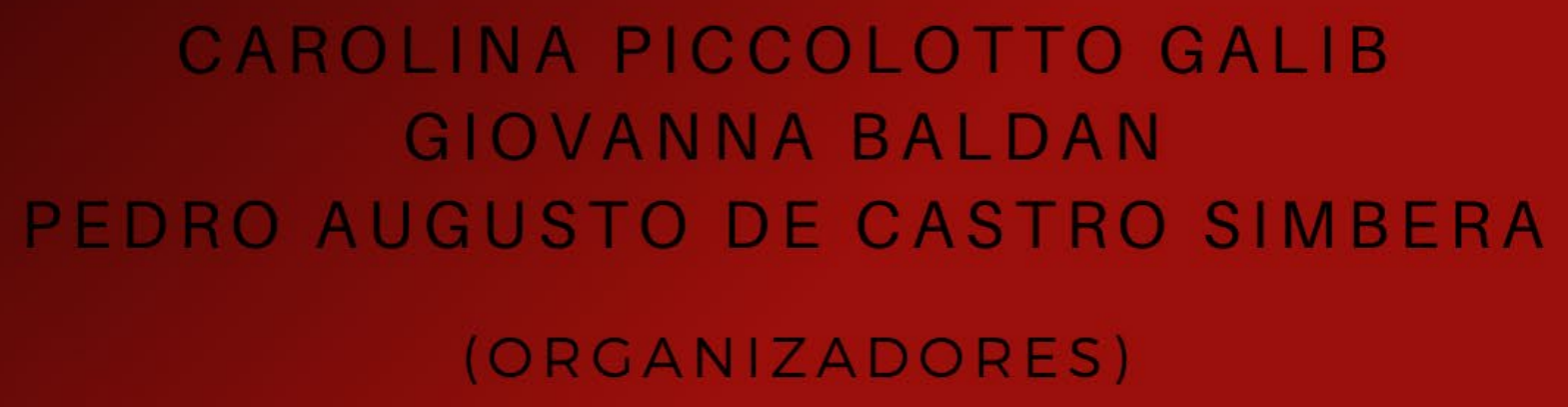

PRÁTICA JURÍDICA EM DIREITOS HUMANOS: ESTUDOS DE CASOS 